\title{
Identification and quantification of gaseous organic compounds emitted from biomass burning using two-dimensional gas chromatography-time-of-flight mass spectrometry
}

\author{
L. E. Hatch ${ }^{1}$, W. Luo ${ }^{1}$, J. F. Pankow ${ }^{1}$, R. J. Yokelson ${ }^{2}$, C. E. Stockwell ${ }^{2}$, and K. C. Barsanti ${ }^{1}$ \\ ${ }^{1}$ Department of Civil and Environmental Engineering, Portland State University, Portland, Oregon, USA \\ ${ }^{2}$ Department of Chemistry, University of Montana, Missoula, Montana, USA
}

Correspondence to: K. C. Barsanti (barsanti@pdx.edu)

Received: 15 August 2014 - Published in Atmos. Chem. Phys. Discuss.: 10 September 2014

Revised: 19 December 2014 - Accepted: 24 December 2014 - Published: 23 February 2015

\begin{abstract}
The current understanding of secondary organic aerosol (SOA) formation within biomass burning (BB) plumes is limited by the incomplete identification and quantification of the non-methane organic compounds (NMOCs) emitted from such fires. Gaseous organic compounds were collected on sorbent cartridges during laboratory burns as part of the fourth Fire Lab at Missoula Experiment (FLAME4) and analyzed by two-dimensional gas chromatographytime-of-flight mass spectrometry $(\mathrm{GC} \times \mathrm{GC}-\mathrm{ToFMS})$. The sensitivity and resolving power of $\mathrm{GC} \times \mathrm{GC}-\mathrm{ToFMS}$ allowed the acquisition of the most extensive data set of $\mathrm{BB}$ NMOCs to date, with measurements for 708 positively or tentatively identified compounds. Estimated emission factors (EFs) are presented for these compounds for burns of six different vegetative fuels, including conifer branches, grasses, agricultural residue, and peat. The number of compounds meeting the peak selection criteria ranged from 129 to 474 among individual burns, and included extensive isomer groups. For example, 38 monoterpene isomers were observed in the emissions from coniferous fuels; the isomeric ratios were found to be consistent with those reported in relevant essential oils, suggesting that the composition of such oils may be very useful when predicting fuel-dependent terpene emissions. Further, 11 sesquiterpenes were detected and tentatively identified, providing the first reported speciation of sesquiterpenes in gas-phase BB emissions. The calculated EFs for all measured compounds are compared and discussed in the context of potential SOA formation.
\end{abstract}

\section{Introduction}

Biomass burning (BB) emissions can strongly influence tropospheric chemistry and climate (Crutzen and Andreae, 1990). Wildfires and prescribed burns occur globally with highly variable fuel types and burning conditions (van der Werf et al., 2010). Fires lead to high concentrations of particulate matter $(\mathrm{PM})$ and gases, such as nitrogen oxides $\left(\mathrm{NO}_{\mathrm{x}}\right)$, carbon dioxide/monoxide, and non-methane organic compounds (NMOCs) of varying volatilities (Andreae and Merlet, 2001; Yokelson et al., 2013). During plume evolution, these emissions may react photochemically to form secondary pollutants (e.g., ozone) (Goode et al., 2000; Hobbs et al., 2003). The primary emissions and secondary species affect human health and climate. Atmospheric PM is associated with negative health effects, such as cardiovascular and respiratory diseases (Pope and Dockery, 2006). Longrange transport of BB emissions can carry species $>1000 \mathrm{~km}$ from a fire source (Crutzen and Andreae, 1990), thereby extending the health and environmental consequences of smoke well beyond fire-prone regions; for example, transport of Siberian wildfire emissions has contributed to nonattainment of ozone air quality standards in North America (Jaffe et al., 2004).

BB particles can influence the radiative balance of the atmosphere directly by scattering or absorbing solar radiation (Hobbs et al., 1997), and indirectly by acting as cloud condensation nuclei (CCN) (Desalmand and Serpolay, 1985; Reid et al., 2005) and ice nuclei (IN) (Petters et al., 2009). A large number of BB particles in a forming cloud can increase the number of $\mathrm{CCN}$, yielding smaller cloud droplets, thereby 
increasing cloud albedo (Crutzen and Andreae, 1990). This effect may alter precipitation patterns and thus the hydrological cycle (Lohmann and Feichter, 2005; Andreae et al., 2004).

BB is the second largest global source of NMOCs; emitted species may undergo photochemical processing (aging), leading to lower volatility or more soluble compounds that can condense into existing particles and form secondary organic aerosol (SOA) (Kroll and Seinfeld, 2008; Hallquist et al., 2009). Laboratory and field studies have shown a wide range of organic aerosol (OA) mass enhancement ratios $(<1$ to 4) following aging of BB smoke (Grieshop et al., 2009; Hennigan et al., 2011; Ortega et al., 2013; Jolleys et al., 2012; Yokelson et al., 2009; Akagi et al., 2012; Wigder et al., 2013; Vakkari et al., 2014), demonstrating high variability in BB emissions and/or plume chemistry. Further, Hennigan et al. (2011) reported extensive oxidation of BB primary OA (POA) during laboratory aging experiments, suggesting that physicochemical properties of OA may change regardless of net loss or production of OA mass. Highly oxidized SOA and aged POA components can influence particle hygroscopicity (Saxena et al., 1995) and CCN activity, thereby exacerbating the effects of BB-derived particles on biogeochemical cycles and planetary albedo.

Efforts toward understanding SOA formation in BB plumes have been hindered by limited identification and quantification of the NMOCs emitted by fires (Akagi et al., 2011). In a recent study using data from openpath Fourier-transform infrared spectroscopy (OP-FTIR), proton-transfer reaction ion-trap mass spectrometry, and gas chromatography-mass spectrometry (GC-MS), only $\sim 50$ $70 \%$ of measured gas-phase organic mass was identified (Warneke et al., 2011; Yokelson et al., 2013), with the majority of the remaining mass likely having lower volatility than the NMOCs routinely measured in BB studies. Thus, there is a need to better characterize NMOCs in BB smoke. Further, studies have demonstrated that known SOA precursors alone cannot explain observed OA growth in aged BB smoke (Grieshop et al., 2009; Ortega et al., 2013). Given the potentially significant production of SOA from BB, improved measurements of gas-phase SOA precursors within smoke plumes are essential for understanding the health and climate impacts of BB particles.

Whereas traditional one-dimensional (1-D) GC-MS has been extensively applied toward the characterization of BB emissions (Christian et al., 2004; Simpson et al., 2011; Ciccioli et al., 2001), GC $\times \mathrm{GC}$ has seen limited application in this field (Ma et al., 2010; Ma and Hays, 2008; Nara et al., 2006). GC $\times$ GC employs two columns to extend the separation capabilities allowed by 1-D GC. Typically, a nonpolar column is utilized for the primary separation based on volatility; slices of the analyte flow are directed to a second column for separation according to polarity or polarizability (Beens et al., 1998). Several characteristics (Mondello et al., 2008) of two-dimensional gas chromatography-time-of- flight mass spectrometry $(\mathrm{GC} \times \mathrm{GC}-\mathrm{ToFMS})$ make it a powerful tool for characterizing the highly complex gas-phase components of smoke. These are (1) high resolving power provides enhanced chromatographic separation, (2) thermal modulation at the interface of the primary and secondary columns refocuses eluting peaks leading to significant improvements in signal-to-noise ratio and thus sensitivity, (3) high ToFMS spectral collection rate allowing up to 500 full mass spectra $(m / z 34-500)$ to be obtained for a given peak eluting from the secondary column (the time evolution of the mass spectra can help deconvolute co-eluting compounds), and (4) distinct compound classes form patterns in the 2-D retention space aiding in compound classification. Herein, the first application of GC $\times$ GC to broadly characterize the gas-phase emissions of BB is described, including comparisons among the emissions from burns of selected conifer, grass, crop residue, and peat fuel types.

\section{Experimental}

\subsection{FLAME-4 sampling}

Samples were collected during the fourth Fire Lab at Missoula Experiment (FLAME-4) from 3 to 12 November 2012 in Missoula, Montana. An overview of FLAME-4 has been provided by Stockwell et al. (2014). Controlled burns were conducted in the combustion laboratory of the US Forest Service Fire Science Laboratory (FSL) using a variety of vegetative fuels. The combustion laboratory is described in detail elsewhere (Christian et al., 2004). In these room burn experiments, smoke was allowed to mix throughout the FSL combustion chamber $(12.5 \mathrm{~m} \times 12.5 \mathrm{~m} \times 22 \mathrm{~m})$; the smoke comprised a mixture of emissions from flaming and smoldering combustion.

\subsubsection{Fuels}

The fuel treatment during FLAME-4 has been described by Stockwell et al. (2014). In general, fuel samples were shipped to the FSL and stored from a few days to a few months with longer-term storage occurring in a humidified refrigerator; instances identified where storage time may have influenced emissions are noted in Sect. 3.3. Prior to ignition, each fuel sample was arranged to promote burning under fieldrelevant conditions (e.g., grasses were standing upright instead of piled). Emissions were sampled from fires of six different globally relevant fuels: black spruce (BS), ponderosa pine (PP), wiregrass (WG), giant cutgrass (CG), Chinese rice straw (RS), and Indonesian peat (IP).

BS (Picea mariana) and PP (Pinus ponderosa) are coniferous trees native to North America. BS is common throughout many fire-prone ecosystems in the boreal forest of Canada and Alaska (Cumming, 2001). The BS sample was obtained near Fairbanks, Alaska. PP forests are common throughout the western USA/Canada and experience extensive pre- 
scribed burning and wildfire activity (e.g., Veblen et al., 2000). The PP sample was obtained locally in Missoula, Montana. Intact boughs (woody material and needles) were burned in the FLAME-4 fires.

Both grassland fuels analyzed - giant CG (Zizaniopsis miliacea) and WG (Aristida stricta) - predominantly grow in the southeastern USA. Prescribed burning is common throughout the southeastern USA as a means of hazard reduction and reforestation (Haines and Busby, 2001). Although CG typically grows in fresh or brackish marshes, these grasslands are still susceptible to burning and prescribed fires are often used within these ecosystems (Wade et al., 2000). WG is a bunchgrass commonly associated with longleaf pine forest ecosystems throughout the southern coastal plains. These ecosystems have been shown to benefit from frequent prescribed burning (Brockway and Lewis, 1997).

RS (Oryza sativa) is an agricultural waste product commonly burned throughout Asia to clear fields. The RS sample was obtained from China, where the majority of BB has been attributed to crop residue (Streets et al., 2003). A peat sample was also imported from Indonesia, where $80 \%$ of the peatlands in Southeast Asia are located (Chang and Song, 2010). Extensive deforestation and drainage of peatlands throughout Indonesia have greatly increased the susceptibility of peat to fire activity (Heil, 2007). Because peat deposits can be very deep and may smolder for months at a time (Heil, 2007), peat fires can be a major source of pollution to the atmosphere (Page et al., 2002).

\subsubsection{Adsorption-thermal desorption cartridge samples}

Adsorption-thermal desorption (ATD) cartridges were used to collect gaseous NMOCs. The cartridges were $8.9 \mathrm{~cm}$ long $\times 0.64 \mathrm{~cm}$ o.d. stainless steel tubes with an inert, internal SilcoTek coating; each cartridge contained a dual-sorbent bed composed of $100 \mathrm{mg}$ Tenax TA 35/60 and $200 \mathrm{mg}$ Carbograph 1 TD 60/80 in series (Camsco, Inc., Houston, TX). The use of multiple sorbents permits compounds with a wide range of volatilities to be collected (Pankow et al., 2012). Prior to shipment to the field, each cartridge was conditioned at $\sim 290^{\circ} \mathrm{C}$ for $1 \mathrm{~h}$ with a continuous flow of pre-cleaned helium $\left(\sim 250 \mathrm{~mL} \mathrm{~min}^{-1}\right)$.

A glass-fiber filter coated with sodium thiosulfate was placed upstream of the cartridge in the sampling train to prevent particles and ozone from reaching the sorbent (Helmig, 1997). In separate tests, these filters were found to scrub ozone at $\sim 760 \mathrm{ppb}$ with greater than $90 \%$ efficiency from $\sim 3 \mathrm{~L}$ sample volume and were thus considered sufficient for removing the negligible ozone expected in fresh $\mathrm{BB}$ smoke (Akagi et al., 2013). A new filter was used with each sample. The filter holder, sampling line, and all fittings were Teflon. Background samples were taken shortly before fire ignition. Smoke samples were collected after the smoke had equilibrated throughout the burn chamber. Break- through tests were conducted wherein two cartridges were placed in series to determine which compounds were incompletely trapped on a single cartridge. All sample volumes were $\sim 2 \mathrm{~L}$, with collection taking place over $15 \mathrm{~min}$ at a flow rate of $\sim 150 \mathrm{~mL} \mathrm{~min}^{-1}$. After sampling, the ATD cartridges were sealed with compression fittings using Teflon ferrules, and stored at $<0^{\circ} \mathrm{C}$. The samples were analyzed within 1 month of sampling.

\subsubsection{Filter-desorption samples}

To characterize the volatilizable NMOCs that were not detected in the gas-phase cartridge samples, PM samples were collected on glass-fiber filters $(0.7 \mu \mathrm{m}$ pore size, $\sim 8 \mathrm{~L} \mathrm{~min}^{-1}, \sim 60 \mathrm{~min}$ ). Prior to shipment to the field, the glass-fiber filters were baked at $\sim 130^{\circ} \mathrm{C}$ for $\sim 8 \mathrm{~h}$. Following sample collection, the filters were immediately packaged in pre-baked aluminum foil and stored at $<0^{\circ} \mathrm{C}$ for up to 1 day prior to desorption. Volatilizable NMOCs were desorbed by passing clean $\mathrm{N}_{2}$ through each filter $\left(150 \mathrm{~mL} \mathrm{~min}^{-1}\right)$ at room temperature and trapped on an ATD cartridge. The clean $\mathrm{N}_{2}$ source was supplied by scrubbing laboratory-grade $\mathrm{N}_{2}$ with two ATD cartridges in series. Comparison of the data from the second scrubber cartridges with those from blank cartridges indicated that the contaminants in the $\mathrm{N}_{2}$ carrier gas were effectively removed. As separate quality control tests, a blank filter and a background PM sample (collected in the burn chamber prior to ignition) were treated by the same desorption method. Although the quality control tests indicated that background PM was near zero, compounds detected in the BB filter-desorption samples were not quantified. We report only the compounds identified from the filters that were not detected in the blank, background sample, or in the cartridge samples (with the exception of $\geq \mathrm{C}_{14}$ hydrocarbons because they were detected in only one cartridge sample).

\subsection{Chemical standards}

Calibration curves were determined for $\sim 275$ standard compounds in order to positively identify and quantify these components (listed in boldface in Table A1). Standards were prepared from (1) a commercial mixture (P-I-A-N-O mix, Sigma Aldrich, St. Louis, MO) containing $\sim 140$ compounds (alkanes, alkenes, and aromatic hydrocarbons) that was injected $(5.0 \mu \mathrm{L})$ into a pre-cleaned and purged $2 \mathrm{~L}$ glass reservoir to produce a gas-phase standard, and (2) individual compounds dissolved in methanol. Seven standards (concentration levels) each were made from the P-I-A-N-O mix and methanol solution. Each standard was injected onto an ATD cartridge and carried into the sorbent bed by a flow $(\sim 50-$ $75 \mathrm{~mL} \mathrm{~min}^{-1}$ ) of pre-cleaned helium.

Initial analyses of the P-I-A-N-O standards indicated that alkanes $>\mathrm{C}_{10}$ remained partially adsorbed to the walls of the glass reservoir. To determine appropriate corrections, 
the P-I-A-N-O standards were analyzed using a $\mathrm{GC} \times \mathrm{GC}$ instrument with flame ionization detection (FID). Because mass-based FID response factors (RFs; area counts ng ${ }^{-1}$ ) are approximately independent of carbon number (Tong and Karasek, 1984), the GC $\times$ GC-FID data were used to estimate the mass percentage present in the gas phase at the time of cartridge spiking for each of the $>\mathrm{C}_{10}$ alkanes by comparison to the average RF measured for $\mathrm{C}_{7}-\mathrm{C}_{9}$ alkanes. The measured gas-phase percentages ranged from $\sim 96 \%$ for decane to $\sim 33 \%$ for pentadecane. The adjusted mass amounts were used in the $\mathrm{GC} \times \mathrm{GC}-\mathrm{ToFMS}$ calibration curves.

\subsection{ATD cartridge analyses}

Samples and standards were analyzed using a Pegasus 4-D GC $\times$ GC-ToFMS (Leco Corp., St. Joseph, MI). Each ATD cartridge was desorbed using an ATD 400 system (PerkinElmer, Waltham, MA) connected to the GC $\times$ GC injection port via a fused silica transfer line at $225^{\circ} \mathrm{C}$. The flow direction through the cartridge during desorption was the reverse of that for sampling to prevent lower volatility analytes from contacting the Carbograph sorbent. Each cartridge was desorbed $\left(285^{\circ} \mathrm{C}, 10 \mathrm{~min}, 40 \mathrm{~mL} \mathrm{~min}^{-1}\right)$ onto a Tenax focusing trap $\left(-20^{\circ} \mathrm{C}\right)$. That trap was then desorbed $\left(300^{\circ} \mathrm{C}\right.$, $3 \mathrm{~min}$ ) to transfer the analytes to the $\mathrm{GC} \times \mathrm{GC}$ injection port. The injection split ratio was $10: 1$. The analytical column set included a DB-VRX primary column $(30 \mathrm{~m}, 0.25 \mathrm{~mm}$ I.D., $1.4 \mu \mathrm{m}$ film, Agilent, Santa Clara, CA) and a Stabilwax secondary column $(1.5 \mathrm{~m}, 0.25 \mathrm{~mm}$ I.D., $0.5 \mu \mathrm{m}$ film, Restek, Bellefonte, PA). The GC $\times$ GC-ToFMS conditions are summarized in Table 1.

Samples were processed using the ChromaTOF software package (Leco Corp., St. Joseph, MI). A peak was discarded if its area was < 200000 units or if the mass spectral match similarity relative to the National Institute of Standard Technology (NIST) mass spectral database was $<750$ (out of 1000). The concentration of each compound measured in the corresponding background sample was subtracted from the concentration determined in the smoke sample. For the PP and IP smoke samples, background samples were unavailable; the background measurements for the other four samples were averaged and applied instead. For these two fuels, standard deviations were applied as the uncertainty in the average background concentrations; among the four background samples, concentrations varied $\sim 10-160 \%$ of the average. Compounds were removed from consideration if their concentrations were negative or not significantly different from zero following background subtraction.

Cases of ambiguous isomer assignments (because an authentic standard had not been used) were based whenever possible on published retention indices (e.g., Sojak et al., 1973, 1984; Stein, 2013). Otherwise, peaks were characterized here solely by chemical formula as assigned by the best mass spectral match(es).
Each positively identified compound (i.e., standard available) was quantified using calibration curves. Tentatively identified analytes were quantified using the calibration curve of the most chemically similar standard compound, as determined by comparing functional groups, carbon number, degree of unsaturation/conjugation, and aromaticity. Given the large number $(\sim 275)$ and wide range (Table A1) of standard compounds analyzed in this work, reasonable surrogate standard compounds were available for most of the compounds detected in the BB samples. With a few exceptions (noted below), all components were calibrated using the deconvoluted total ion current. For analytes whose peak areas were low (calibration curves yielded negative concentrations), RFs (area counts ng ${ }^{-1}$ ) were used instead. Error bars were calculated from the standard error in the linear regression of the calibration curve or the standard deviation of the average RF. The uncertainty for positively (tentatively) identified compounds was set to a minimum of $20 \%(50 \%)$. Mixing ratios used in determining emission factors (EFs) (see Sect. 3.2) were calculated using the ambient temperature and pressure measured in the burn chamber. For the benzene and toluene peaks in some cartridge samples, the MS detector was saturated for the major ions in the mass spectra; thus, these compounds were quantified using a minor ion. The same approach was required for camphene in the BS cartridge sample. The reported values for these species likely reflect lower limits due to the limited dynamic range.

\section{Results and discussion}

\subsection{Scope of the GC $\times$ GC data}

The GC $\times$ GC-ToFMS chromatograms of the cartridge samples from the six burns, highlighting the complexity of BB emissions, are shown in Figs. 1-6; the compounds detected are listed in Table A1 (and in spreadsheet format in Table S1 in the Supplement). The data have been organized into major chemical classes (panel b of Figs. 1-6 and Table A1). For reference, an example chromatogram highlighting regions of the major chemical classes is included in the Supplementary Material. Compounds with a wide range of volatilities and functionality were detected, from $\mathrm{C}_{3}$ polar compounds through $\mathrm{C}_{15}$ hydrocarbons (Table A1). The range of detectable compounds was limited by the cartridge sampling and analysis conditions.

Sesquiterpenes ( $p_{\mathrm{L}}^{o} \sim 1 \times 10^{-3} \mathrm{kPa}$ at $25^{\circ} \mathrm{C}$, Helmig et al., 2003) were among the least volatile compounds observed. Less volatile and/or more polar compounds may have adsorbed into the filter used upstream of the sampling cartridge to remove particles and ozone. In addition to potential sampling losses, highly polar gases are not amenable to determination by GC. For instance, analysis of standards demonstrated that hydroxy phenols (e.g., resorcinol) did not elute from the column set used for this work. Further, with 
Table 1. GC $\times$ GC-ToFMS Conditions.

\begin{tabular}{ll}
\hline & Setting \\
\hline GC injector & $225^{\circ} \mathrm{C}, 10: 1 \mathrm{split}$ \\
Column flow & $1.20 \mathrm{~mL} \mathrm{~min}-1$ \\
Primary column & DB-VRX, $30 \mathrm{~m}, 0.25 \mathrm{~mm}$ I.D., $1.4 \mu \mathrm{m}$ film (Agilent, Santa Clara, CA) \\
Primary oven program & $45^{\circ} \mathrm{C}$ for $5 \mathrm{~min}, 4^{\circ} \mathrm{C} \mathrm{min}-1$ to $235^{\circ} \mathrm{C}, 235^{\circ} \mathrm{C}$ for $2.5 \mathrm{~min}$ \\
GC $\times$ GC Modulation & $5 \mathrm{~s}$ period, $1.10 \mathrm{~s}$ hot pulse \\
GC $\times$ GC Modulator & Trapped with cold gas from LN2, then hot pulse at $25^{\circ} \mathrm{C}$ above \\
& primary oven for release to secondary column \\
Secondary column & Stabilwax, $1.5 \mathrm{~m}, 0.25 \mathrm{~mm}$ I.D., $0.5 \mu \mathrm{m}$ film (Restek, Bellefonte, PA) \\
Secondary oven & $15^{\circ} \mathrm{C}$ above primary oven \\
MS source & $200^{\circ} \mathrm{C}$, Electron impact, $70 \mathrm{eV}$ \\
MS detector & $1500 \mathrm{~V}$ \\
MS data acquisition & $227 \mathrm{spectra} \mathrm{s}{ }^{-1}, 34-500 \mathrm{amu}$ \\
\hline
\end{tabular}

the Stabilwax secondary column utilized, several polar compounds (e.g., phenols and furfurals) wrapped around (i.e., did not elute within one modulation period). Such peaks are thus very broad in the second dimension and may also appear in regions of the chromatogram typical of significantly less polar compounds. These features are most pronounced for the RS sample (Fig. 5), which contained the highest fraction of oxygenated compounds. Such wraparound effects should not have influenced the quantification of the positively identified compounds because these effects were captured in the calibration curves. For a limited number of compounds, wraparound may have influenced quantifications of tentatively identified compounds that wrapped around and were quantified with a surrogate standard compound that did not (or vice versa).

On the high end of the volatility range, we have omitted all compounds eluting before 3-methyl-1-butene ( $p_{\mathrm{L}}^{o} 120 \mathrm{kPa}$ at $25^{\circ} \mathrm{C}$, Linstrom and Mallard, 2014), the earliest eluting $\mathrm{C}_{5}$ hydrocarbon (HC). $\mathrm{HCs} \leq \mathrm{C}_{3}$ were not trapped by the Tenax/Carbograph cartridges. Although $\mathrm{C}_{4}$ HCs were detected, they displayed high breakthrough; the lightest standard $\left(\mathrm{C}_{5}\right)$ HC compounds exhibited minimal breakthrough and thus could not be used to quantify the observed $\mathrm{C}_{4}$ compounds. Light $\left(\leq \mathrm{C}_{4}\right) \mathrm{HCs}$ have been previously shown to dominate the overall HC emissions from BB (Schauer et al., 2001; Akagi et al., 2011); however, these components have been generally well characterized by other methods (e.g., canister samples, Simpson et al., 2011) and typically are not significant precursors to atmospheric SOA (Seinfeld and Pankow, 2003).

Although several reported oxygenated compounds displayed high breakthrough as well, appropriate standard compounds allowed reasonable quantification. For such compounds, the corresponding standards showed evidence of breakthrough based on the GC $\times$ GC-FID data; thus, application of the calibration curve somewhat corrects for the low trapping efficiency. However, comparison with co-located measurements (not shown) indicates that our measured con- centrations of acetone and acetonitrile were comparatively low and therefore values reported here should be considered a lower limit. The same may be true of acrolein, although quantified co-located measurements were not available to verify the results. Such compounds are listed in italics in Table A1. Furan also displayed very poor trapping efficiency in the samples and standards. However, tests showed that the breakthrough was quite consistent and application of the calibration curves yielded results in good agreement with colocated measurements; thus, we expect the reported values of furan to be accurate. A full comparison of all FLAME-4 NMOC measurements will be presented in a future publication.

\subsection{Emission factors}

Emission factors ( $\mathrm{g} \mathrm{kg}^{-1}$ of dry fuel burned) were calculated by the carbon mass balance method (Yokelson et al., 1999; Stockwell et al., 2014):

$\mathrm{EF}_{\mathrm{X}}=F_{\mathrm{C}} \times \frac{\mathrm{MM}_{\mathrm{X}}}{\mathrm{MM}_{\mathrm{C}}} \times \frac{\frac{\Delta \mathrm{X}}{\Delta \mathrm{CO}_{2}}}{\sum_{i}^{n}\left(\mathrm{NC}_{i} \times \frac{\Delta \mathrm{Y}_{i}}{\Delta \mathrm{CO}_{2}}\right)}$.

$F_{\mathrm{C}}$ is the mass fraction $\left(\mathrm{g} \mathrm{kg}^{-1}\right)$ of carbon in the dry fuel and was measured for each fuel by an independent laboratory (Table A1). MMX and $\mathrm{MM}_{\mathrm{C}}$ are the molar masses of compound $\mathrm{X}$ and carbon, respectively. $\Delta \mathrm{X}$ is the backgroundsubtracted (excess) mixing ratio of compound $\mathrm{X} ; \Delta \mathrm{X} / \Delta \mathrm{CO}_{2}$ (or $\Delta \mathrm{Y} / \Delta \mathrm{CO}_{2}$ ) is the emission ratio (ER) of compound $\mathrm{X}$ (or $\mathrm{Y}$ ) relative to $\mathrm{CO}_{2}$ (ERs are also commonly referenced to $\mathrm{CO}$ for smoldering compounds). $\mathrm{NC}_{i}$ is the number of carbon atoms in compound $\mathrm{Y}_{i}$. The summation represents the total carbon emitted during combustion, assuming complete volatilization; it includes $\mathrm{CO}_{2}, \mathrm{CO}$, and $\mathrm{C}_{1-3}$ alkanes/alkenes, as measured by OP-FTIR (Stockwell et al., 2014) and averaged over the corresponding cartridge sampling periods. Strictly speaking, the summation should also include minor NMOCs and particulate carbon; however, ig- 
(a)

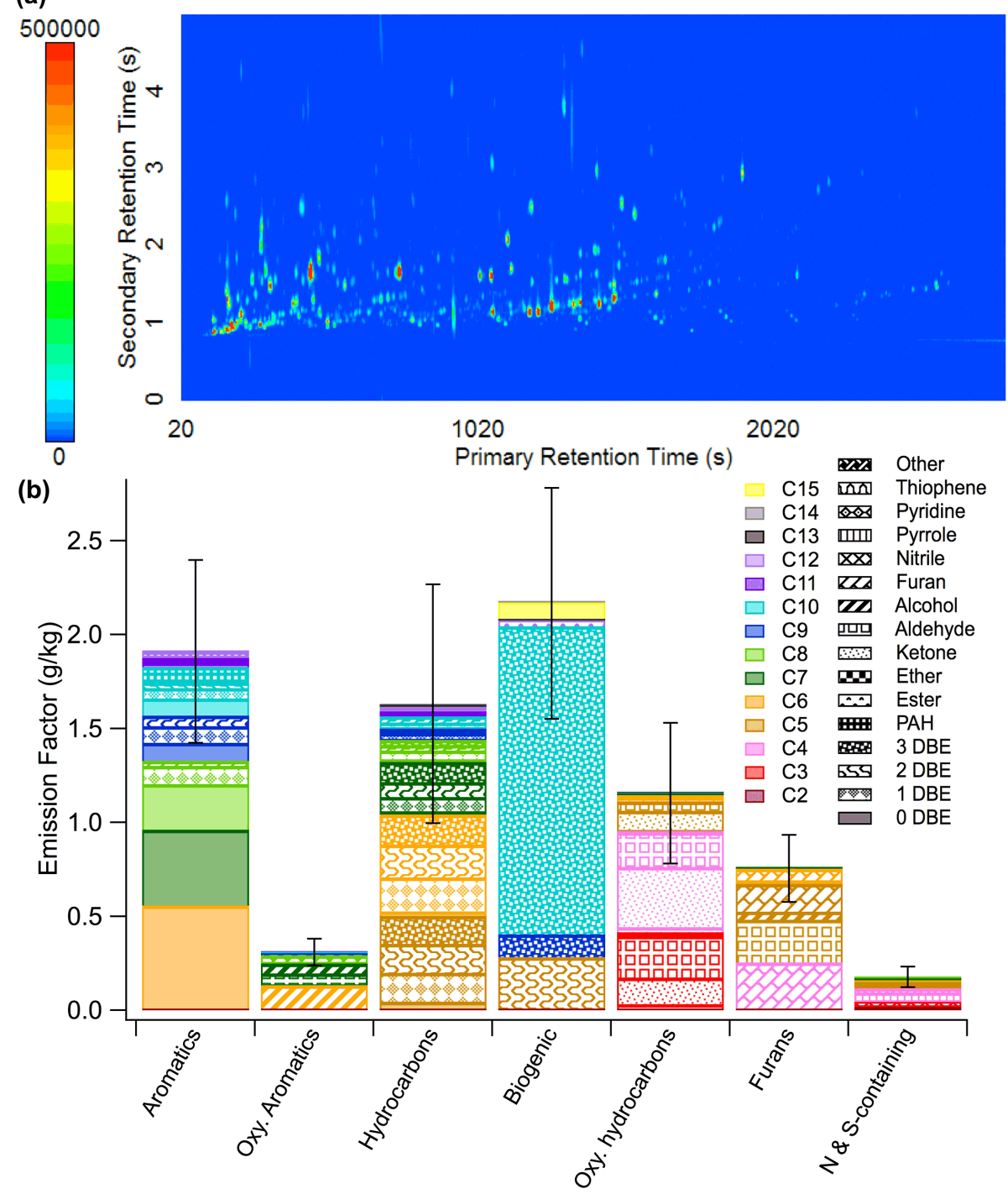

Figure 1. (a) GC $\times$ GC-ToFMS chromatogram of NMOC emissions from a black spruce (BS) fire. The color scale saturates at 500000 area units. (b) Summary of the compounds observed by GC $\times$ GC-ToFMS during the BS fire. Colors indicate carbon number and patterns indicate functionality. (DBE are double bond equivalents, which for aromatic compounds refers to the substituents only.)

noring these components introduces errors on the order of only a few percent (Yokelson et al., 2013), which is well within the reported uncertainties.

The fire-integrated modified combustion efficiencies (MCEs; $\left.\Delta \mathrm{CO}_{2} /\left(\Delta \mathrm{CO}_{2}+\Delta \mathrm{CO}\right)\right)$ for the six burns are included in Table A1. MCE is a measure of the relative contributions of flaming and smoldering combustion (Yokelson et al., 1996). Higher values (approaching 0.99) are indicative of pure flaming combustion, whereas lower values $(\sim 0.8)$ indicate pure smoldering combustion. Intermediate values reflect a mix of flaming and smoldering combustion.

MCEs and EFs for the PP and BS burns were compared to those presented by Yokelson et al. (2013) for coniferous canopy fires. The MCEs in this work (PP, 0.927 and
BS, 0.933) are similar to that reported by Yokelson et al. (2013) $(0.925 \pm 0.036)$. In a correlation plot, the EFs for 48 overlapping compounds (Fig. 7) are scattered about the $1: 1$ line, demonstrating that there was no systematic difference in these laboratory measurements relative to Yokelson et al. (2013). Of the disparate points, several reflect monoterpene isomers, whose emissions can vary significantly among different plant species (see Sect. 3.3.5).

The MCE of the IP burn (0.832) in this work was nearly identical to a laboratory IP burn (0.838) of Christian et al. (2003). However, the calculated EFs for IP smoke (Table A1) are $\sim 2-7$-fold lower than those reported by Christian et al. (2003) for the six overlapping compounds. For comparison, the EFs based on OP-FTIR measurements for 
(a)

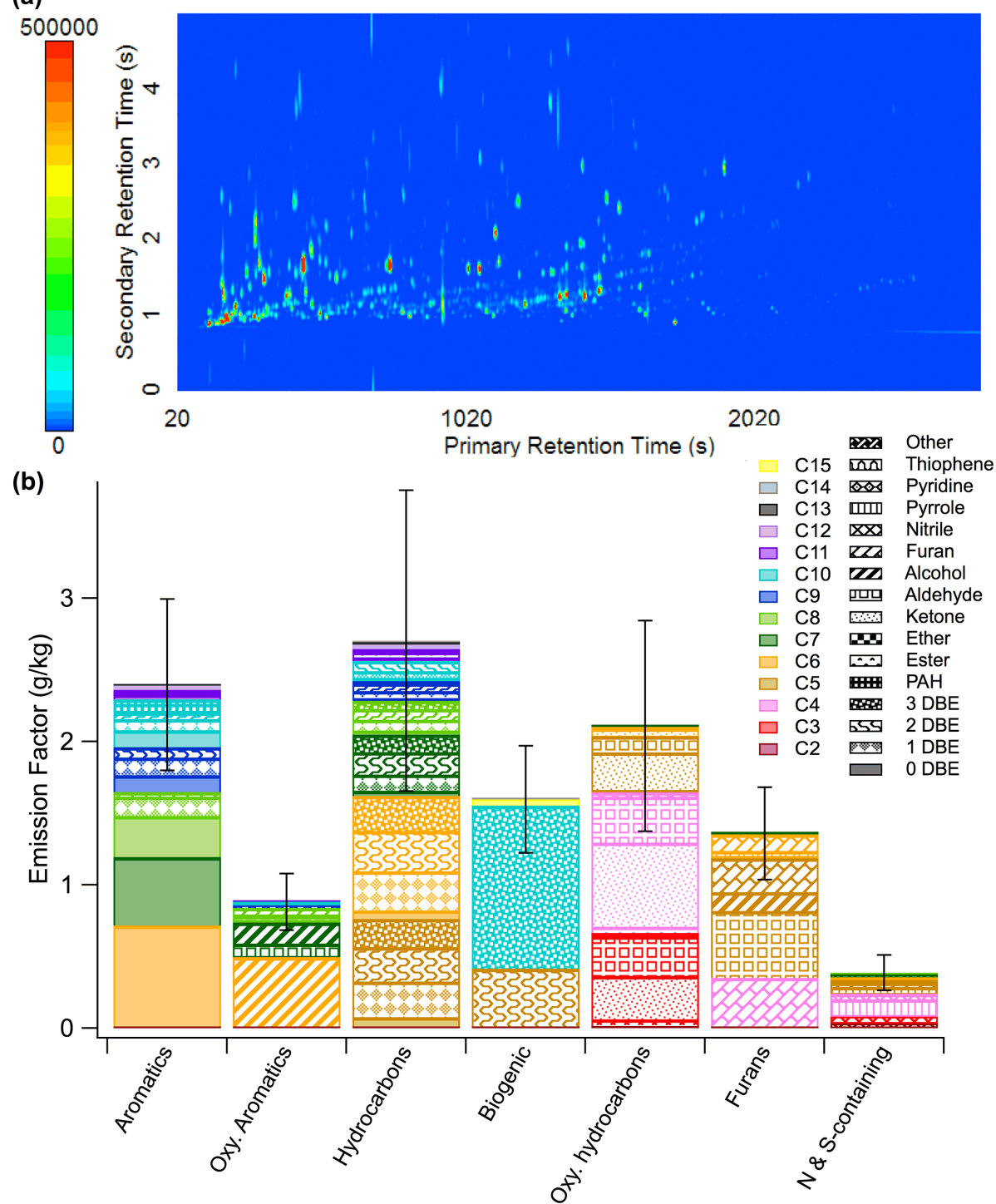

Figure 2. As in Fig. 1, for a ponderosa pine fire.

the FLAME-4 IP burns (Stockwell et al., 2014) averaged $\sim 9$-fold lower to $\sim 3$-fold higher than those by Christian et al. (2003). The differences in measured EFs likely arose from the different peat samples: the FLAME-4 peat sample was obtained from a previously burned/logged peat forest in Kalimantan, whereas the peat burned by Christian et al. (2003) came from Sumatra. Given the wide variability in reported EFs, additional measurements of IP fire emissions should be undertaken to help constrain their EFs. Christian et al. (2003) have also reported emissions from Indonesian RS. The MCE during their burn (0.811) was much lower than that of the Chinese RS fire measured in this study (0.942); thus, the compounds emitted from smoldering combustion were significantly higher in the Christian et al. (2003) study. The different combustion conditions were largely due to the fuel orientations. In the study by Christian et al. (2003), RS was burned in a dense pile, as often occurs in non-mechanized agriculture. The FLAME-4 RS sample was burned as unpiled field residue, for which a similar MCE of $\sim 0.93$ has been measured for RS under ambient burn conditions (Oanh et al., 2011). The relative importance of these two orientations is not well known (Akagi et al., 2011).

For the WG and CG fires, there are no available emission measurements for compounds that can be compared with our data.

\subsection{NMOC observations}

Including NMOC emissions from all six burns, a total of 674 compounds were positively or tentatively identified in the gas-phase cartridge samples (Table A1) and a further 
(a)
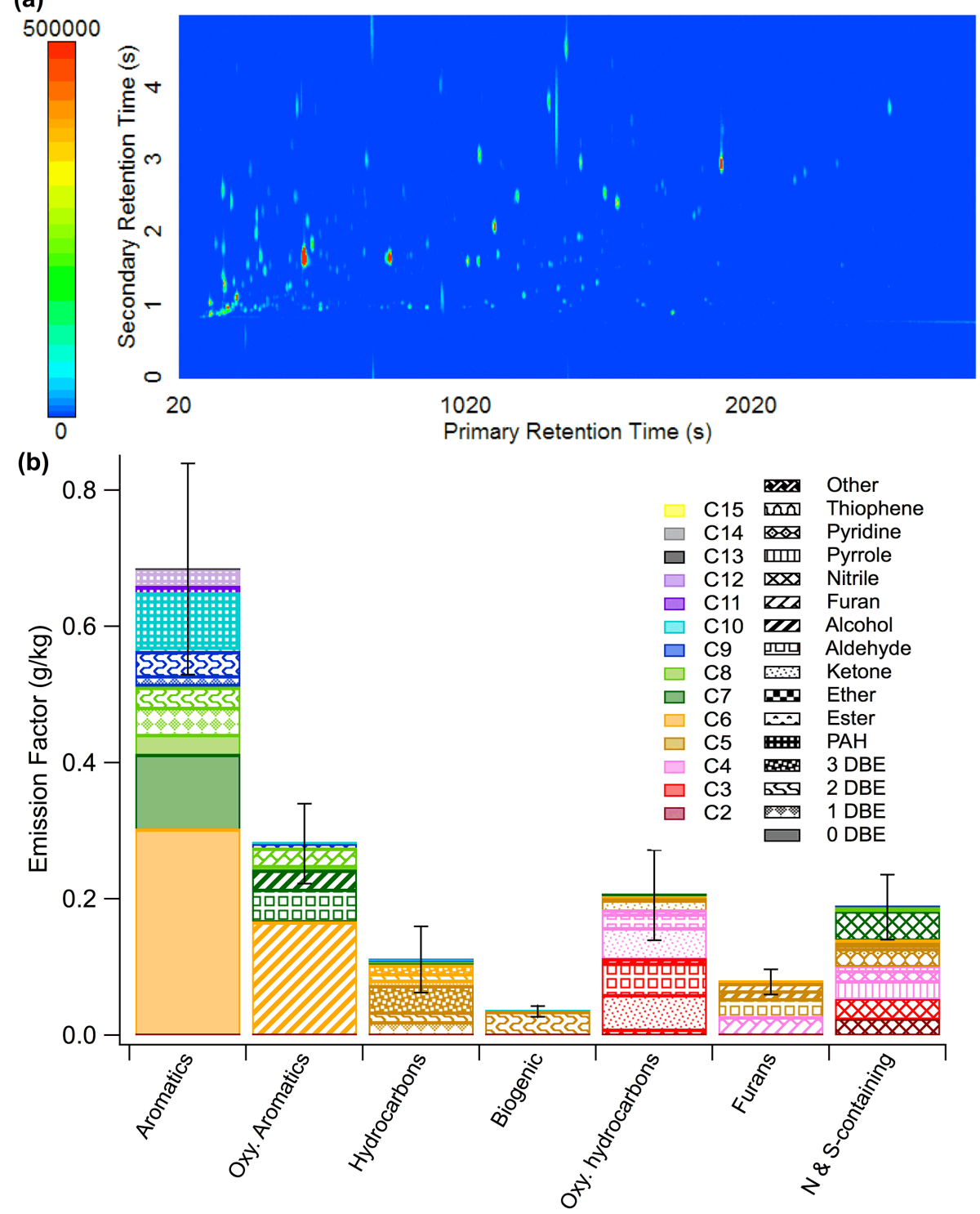

Figure 3. As in Fig. 1, for a giant cutgrass fire.

34 compounds were identified solely in the filter-desorption samples (Table 2). Of the compounds observed in the cartridge samples, $\sim 30-50 \%$ were positively identified across the six burns. There was significant variation in the number of compounds detected in each smoke sample, ranging from 129 (WG) to 474 (PP) (Table A1). The grass fires produced the fewest compounds, as well as the lowest overall NMOC emissions, with total EFs of 1.42 and $1.07 \mathrm{~g} \mathrm{~kg}^{-1}$ for CG and WG, respectively, compared to $3.37-14.6 \mathrm{~g} \mathrm{~kg}^{-1}$ for the other fuels (Table A1). The lower emissions cannot be explained by differences in combustion efficiency because the MCE of the CG fire was similar to those from the coniferous fuels, which displayed $\sim 6-8$-fold higher total EF (Table A1).
Abundant isomers were present in nearly all chemical classes, for example, $17 \mathrm{C}_{10} \mathrm{H}_{14}$ isomers (aromatic $\mathrm{HCs}$ ), $29 \mathrm{C}_{7} \mathrm{H}_{12}$ isomers (aliphatic $\mathrm{HCs}$ ), $38 \mathrm{C}_{10} \mathrm{H}_{16}$ isomers (monoterpenes), and $12 \mathrm{C}_{5} \mathrm{H}_{8} \mathrm{O}$ isomers (aldehydes and ketones) were detected. Because chemical structure significantly influences chemical reactivity (Ziemann and Atkinson, 2012), it is advantageous to speciate the compounds in these groups to better predict BB plume chemistry. Although in many cases, specific structures could not be assigned, future availability of additional standard compounds will enable more thorough chemical identification.

Of the 674 compounds detected, only 78 compounds were present in all six cartridge samples (Fig. 8). Most of these were major compounds, defined as EF $>0.01 \mathrm{~g} \mathrm{~kg}^{-1}$ in any sample (e.g., benzene, toluene, and furan). These major com- 
Table 2. Volatilizable compounds observed in the filter-desorption samples. Compounds in bold were positively identified by comparison with commercial standards. No unique compounds were observed in the wiregrass sample (see Sect. 2.1.3).

\begin{tabular}{|c|c|c|c|c|c|c|c|c|}
\hline Compound & Formula & $\begin{array}{r}\text { Primary } \\
\text { RT (s) }\end{array}$ & $\begin{array}{r}\text { Secondary } \\
\text { RT (s) }\end{array}$ & $\begin{array}{l}\text { Black } \\
\text { spruce }\end{array}$ & $\begin{array}{l}\text { Pond. } \\
\text { pine }\end{array}$ & $\begin{array}{l}\text { Cut- } \\
\text { grass }\end{array}$ & $\begin{array}{l}\text { Rice } \\
\text { straw }\end{array}$ & $\begin{array}{l}\text { Ind. } \\
\text { peat }\end{array}$ \\
\hline Eucalyptol & $\mathrm{C}_{10} \mathrm{H}_{18} \mathrm{O}$ & 1479.53 & 1.36 & $\mathrm{x}$ & - & - & - & - \\
\hline $\mathrm{C}_{10} \mathrm{H}_{18} \mathrm{O}$ isomer & $\mathrm{C}_{10} \mathrm{H}_{18} \mathrm{O}$ & 1784.44 & 2.275 & $\mathrm{x}$ & - & - & - & - \\
\hline 4-Ethyl Phenol & $\mathrm{C}_{8} \mathrm{H}_{10} \mathrm{O}$ & 1794.43 & 2.583 & $\mathrm{x}$ & $\mathrm{x}$ & - & $\mathrm{x}$ & - \\
\hline Borneol & $\mathrm{C}_{10} \mathrm{H}_{18} \mathrm{O}$ & 1819.42 & 2.763 & $\mathrm{x}$ & - & - & - & - \\
\hline 2,3-Dimethyl phenol & $\mathrm{C}_{8} \mathrm{H}_{10} \mathrm{O}$ & 1839.42 & 0.304 & - & - & - & $\mathrm{x}$ & - \\
\hline p-Methylguaiacol & $\mathrm{C}_{8} \mathrm{H}_{10} \mathrm{O}_{2}$ & 1894.4 & 4.937 & $\mathrm{x}$ & $\mathrm{x}$ & - & - & $\mathrm{x}$ \\
\hline $\mathrm{C}_{8} \mathrm{H}_{8} \mathrm{O}$ isomer (?) & $\mathrm{C}_{8} \mathrm{H}_{8} \mathrm{O}$ & 1919.39 & 4.268 & $\mathrm{x}$ & $\mathrm{x}$ & - & $\mathrm{x}$ & - \\
\hline Fenchyl acetate & $\mathrm{C}_{12} \mathrm{H}_{20} \mathrm{O}_{2}$ & 1954.38 & 1.5 & $\mathrm{x}$ & - & - & - & - \\
\hline 4-Ethylguaiacol & $\mathrm{C}_{9} \mathrm{H}_{12} \mathrm{O}_{2}$ & 2084.34 & 4.316 & - & $\mathrm{x}$ & - & - & - \\
\hline 1H-Pyrrole, 1-phenyl- & $\mathrm{C}_{10} \mathrm{H}_{9} \mathrm{~N}$ & 2089.34 & 3.296 & - & $\mathrm{x}$ & - & - & - \\
\hline 4-Vinyl guaiacol & $\mathrm{C}_{9} \mathrm{H}_{10} \mathrm{O}_{2}$ & 2169.31 & 0.845 & $\mathrm{x}$ & $\mathrm{x}$ & - & $\mathrm{x}$ & - \\
\hline p-Propylguaiacol & $\mathrm{C}_{10} \mathrm{H}_{14} \mathrm{O}_{2}$ & 2264.28 & 3.903 & - & $\mathrm{x}$ & - & - & - \\
\hline 1,13-Tetradecadiene & $\mathrm{C}_{14} \mathrm{H}_{26}$ & 2269.28 & 1.17 & - & $\mathrm{x}$ & - & - & - \\
\hline 1-Tetradecene & $\mathrm{C}_{14} \mathrm{H}_{28}$ & 2284.28 & 1.118 & $\mathrm{x}$ & $\mathrm{x}$ & - & $\mathrm{x}$ & $\mathrm{x}$ \\
\hline Tetradecane & $\mathrm{C}_{14} \mathrm{H}_{30}$ & 2299.27 & 1.06 & $\mathrm{x}$ & $\mathrm{x}$ & - & $\mathrm{x}$ & $\mathrm{x}$ \\
\hline Naphthalene, 2-ethenyl- & $\mathrm{C}_{12} \mathrm{H}_{10}$ & 2439.23 & 3.137 & - & $\mathrm{x}$ & - & - & - \\
\hline Isoeugenol & $\mathrm{C}_{10} \mathrm{H}_{12} \mathrm{O}_{2}$ & 2449.22 & 0.119 & - & $\mathrm{x}$ & - & - & - \\
\hline Benzene, octyl- & $\mathrm{C}_{14} \mathrm{H}_{22}$ & 2454.22 & 1.514 & - & - & - & - & $\mathrm{x}$ \\
\hline 1-Pentadecene & $\mathrm{C}_{15} \mathrm{H}_{30}$ & 2479.21 & 1.126 & $\mathrm{x}$ & $\mathrm{x}$ & - & - & $\mathrm{x}$ \\
\hline Pentadecane & $\mathrm{C}_{15} \mathrm{H}_{32}$ & 2489.21 & 1.074 & $\mathrm{x}$ & $\mathrm{x}$ & - & $\mathrm{x}$ & $\mathrm{x}$ \\
\hline $\mathrm{C}_{15} \mathrm{H}_{24}$ Isomer & $\mathrm{C}_{15} \mathrm{H}_{24}$ & 2509.2 & 1.474 & - & $\mathrm{x}$ & - & - & - \\
\hline $\mathrm{C}_{15} \mathrm{H}_{24}$ Isomer & $\mathrm{C}_{15} \mathrm{H}_{24}$ & 2584.18 & 1.434 & $\mathrm{x}$ & - & - & - & - \\
\hline $\mathrm{C}_{14} \mathrm{H}_{20}$ isomer & $\mathrm{C}_{14} \mathrm{H}_{20}$ & 2584.18 & 1.914 & - & - & - & - & $\mathrm{x}$ \\
\hline Dibenzofuran & $\mathrm{C}_{12} \mathrm{H}_{8} \mathrm{O}$ & 2614.17 & 3.599 & - & $\mathrm{x}$ & $\mathrm{x}$ & - & - \\
\hline Benzene, nonyl- & $\mathrm{C}_{15} \mathrm{H}_{24}$ & 2649.16 & 1.509 & - & - & - & - & $\mathrm{x}$ \\
\hline 1-Hexadecene & $\mathrm{C}_{16} \mathrm{H}_{32}$ & 2664.15 & 1.135 & - & - & - & - & $\mathrm{x}$ \\
\hline Hexadecane & $\mathrm{C}_{16} \mathrm{H}_{34}$ & 2674.15 & 1.082 & $\mathrm{x}$ & $\mathrm{x}$ & - & - & $\mathrm{x}$ \\
\hline Naphthalene, trimethyl- & $\mathrm{C}_{13} \mathrm{H}_{14}$ & 2759.12 & 2.776 & - & $\mathrm{x}$ & - & - & $\mathrm{x}$ \\
\hline 1-Heptadecene & $\mathrm{C}_{16} \mathrm{H}_{32}$ & 2834.1 & 1.153 & - & - & - & - & $\mathrm{x}$ \\
\hline Heptadecane & $\mathrm{C}_{16} \mathrm{H}_{34}$ & 2844.1 & 1.096 & - & - & - & - & $\mathrm{x}$ \\
\hline Cadalene & $\mathrm{C}_{15} \mathrm{H}_{18}$ & 2884.08 & 2.31 & - & - & - & - & $\mathrm{x}$ \\
\hline 1-Octadecene & $\mathrm{C}_{18} \mathrm{H}_{36}$ & 2999.05 & 1.166 & - & - & - & - & $\mathrm{x}$ \\
\hline Octadecane & $\mathrm{C}_{18} \mathrm{H}_{38}$ & 3009.04 & 1.113 & - & - & - & - & $\mathrm{x}$ \\
\hline Phenanthrene/Anthracene & $\mathrm{C}_{14} \mathrm{H}_{10}$ & 3094.02 & 4.554 & - & $\mathrm{x}$ & $\mathrm{x}$ & - & - \\
\hline
\end{tabular}

pounds accounted for $57-84 \%$ of the total $\mathrm{EF}$ from the burns. Efforts aimed at improving the representation of BB SOA in atmospheric models might begin with this group. Of the 210 compounds unique to a single burn, most were present at low levels (minor; Fig. 8). Aliphatic HCs constituted approximately half of these compounds, due to the large numbers of potential isomers.

To more clearly show the relative proportions of the identified compounds, the data were sorted into groups based on functionality and carbon number (b panels; Figs. 1-6). Because these figures do not include compounds that were not characterized by our approach (e.g., low molecular weight compounds known to have high emissions), they do not provide a full accounting of the NMOC emissions. A complete synthesis of the NMOC measurements during FLAME-4 is underway and will be presented in a separate study. Interest- ing features of each class elucidated by $\mathrm{GC} \times \mathrm{GC}-\mathrm{ToFMS}$, particularly as relevant for SOA formation, are described in the following sections.

\subsubsection{Aromatic hydrocarbons}

Aromatic HCs represented a major fraction of emissions from all fuels (Figs. 1-6), except WG (only $\sim 10 \%$ by EF; Fig. 4); for CG in particular, aromatic HCs were overwhelmingly dominant ( $\sim 43 \%$ by EF; Fig. 3$)$. The majority of the aromatic emissions were alkyl aromatic HCs, in terms of both EF and number of compounds (Table A1), although significant levels of compounds with unsaturated substituents (e.g., styrene, phenylacetylene and their substituted analogs) were also detected in the BS, PP, and CG burn emissions (b panels; Figs. 1-3). In all cases, the most abundant aro- 
(a)
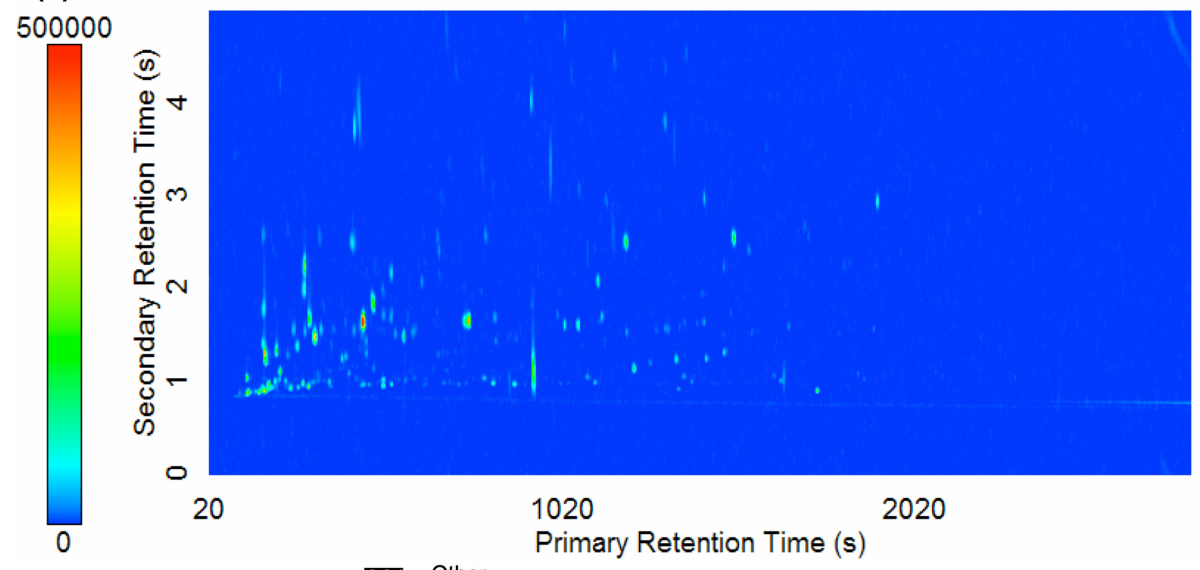

(b)

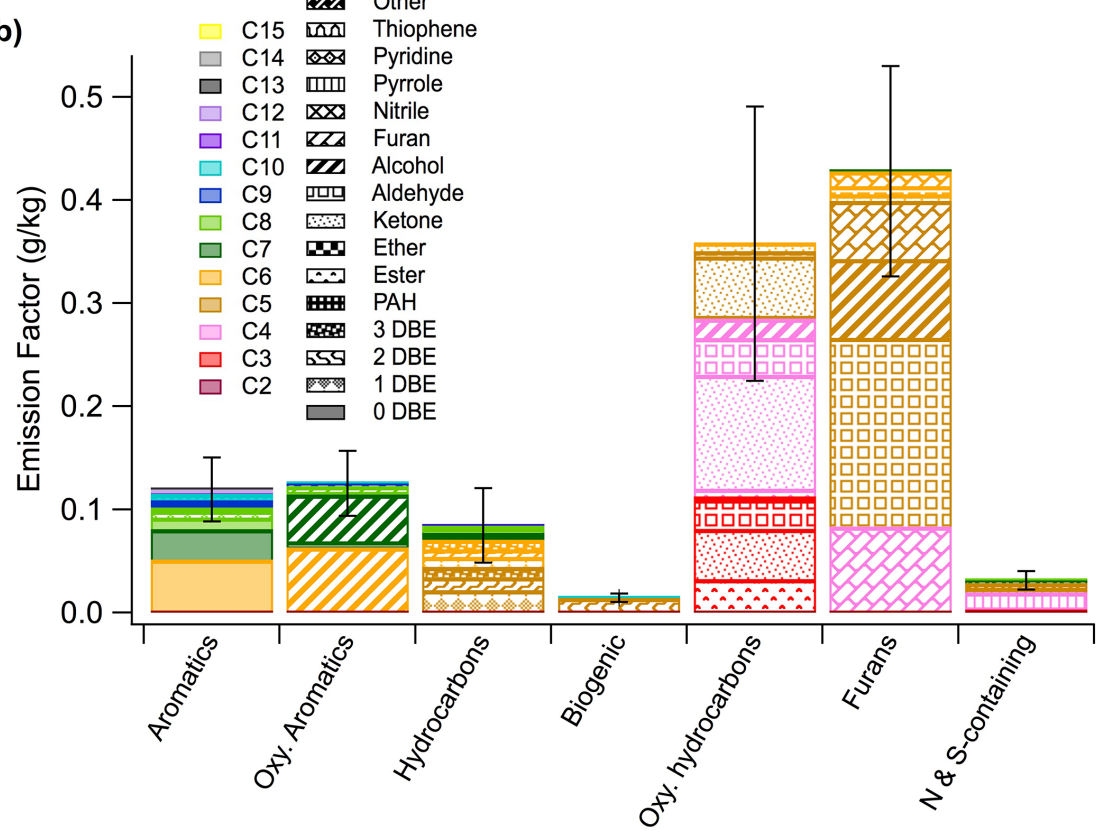

Figure 4. As in Fig. 1, for a wiregrass fire.

matic $\mathrm{HC}$ was benzene, followed by toluene (Table A1), despite being potentially underestimated by our measurements (Sect. 2.3); this is consistent with prior measurements of aromatic HCs in BB emissions (Akagi et al., 2011; Andreae and Merlet, 2001; Yokelson et al., 2013). Further, higher molecular weight (MW) aromatic HCs were detected than are typically reported elsewhere (e.g., $\leq \mathrm{C}_{9}$, Akagi et al., 2011; Andreae and Merlet, 2001; more recently, unspeciated $\mathrm{C}_{11}$ alkyl aromatics, Yokelson et al., 2013). In this work, a number of $\mathrm{C}_{11}$ isomers with substituents of varying double bond equivalents (DBE) (0-2) were detected (Table A1) and in the filter-desorption tests, benzene derivatives as large as nonylbenzene were observed (Table 2). Naphthalene and several methyl naphthalenes as well as related compounds such as biphenyl and acenaphthylene were detected in the emissions from all fuels. Higher MW naphthalene derivatives and poly- cyclic aromatic HCs (PAHs) were tentatively identified in the filter-desorption samples, including a trimethyl-naphthalene isomer and phenanthrene (Table 2).

The chemical structure of aromatic HCs may influence the kinetics and thermodynamics of SOA formation and will vary from plume to plume depending on the isomeric ratios. The atmospheric reactivity of aromatic HCs is dominated by $\mathrm{OH}$ addition, for which the reaction rate increases with the number of alkyl substituents and is further influenced by their position (Ziemann and Atkinson, 2012, and references therein). For example, the rate constant of 1,3,5trimethyl benzene is $\sim 10 \times$ higher than that of $n$-propyl benzene (Finlayson-Pitts and Pitts, 2000). However, similar SOA yields of $\sim 30 \%$ (roughly independent of particle mass concentration) have been measured by $\mathrm{Ng}$ et al. (2007) for benzene, toluene, and $m$-xylene under low- $\mathrm{NO}_{\mathrm{x}}$ conditions (sig- 


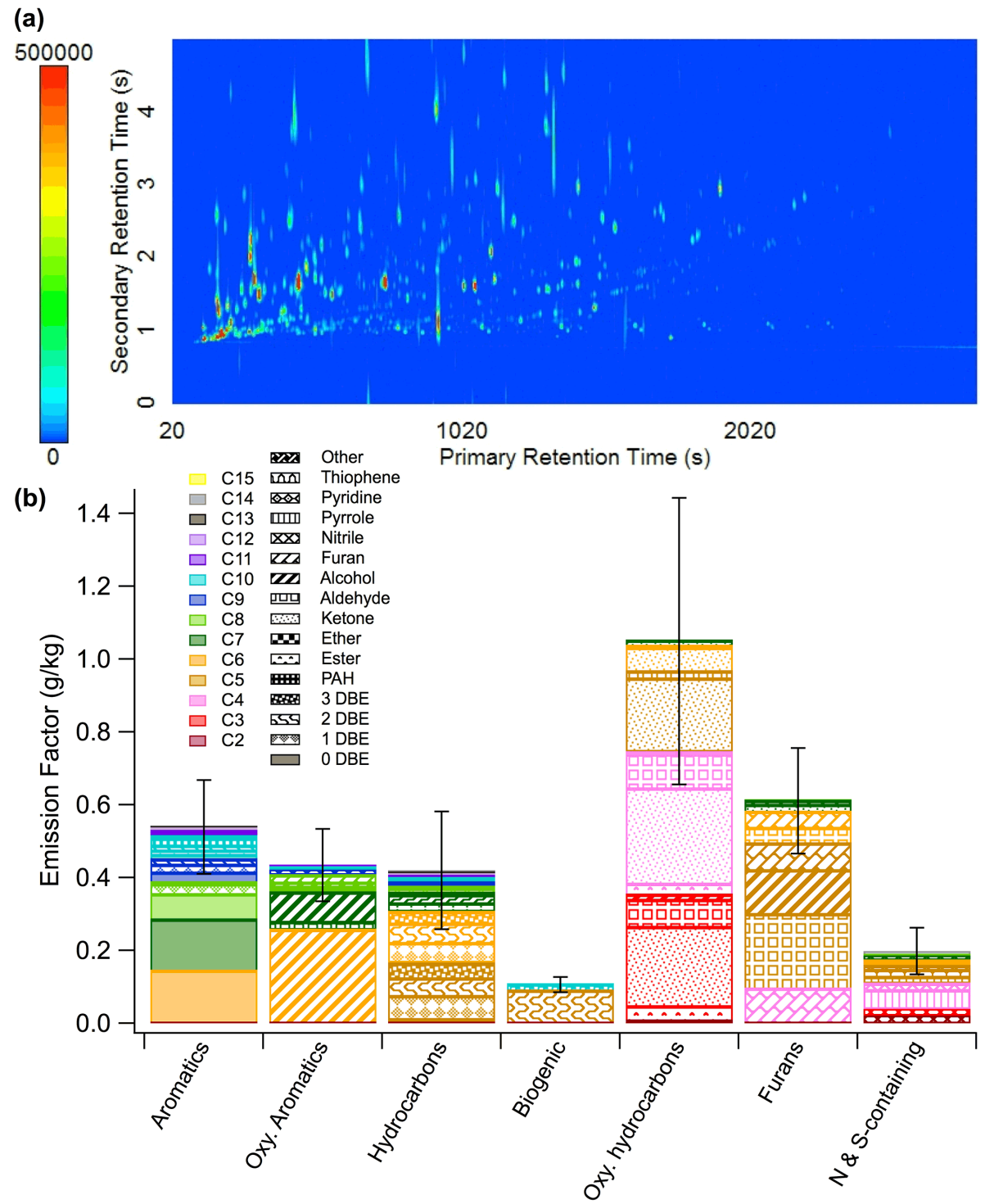

Figure 5. As in Fig. 1, for a Chinese rice straw fire.

nificantly lower yields were observed under high- $\mathrm{NO}_{\mathrm{x}}$ conditions and varied as a function of particle mass concentration). Naphthalene and its derivatives exhibit notably higher SOA yields than the substituted benzenes: up to $\sim 73 \%$ under low$\mathrm{NO}_{\mathrm{x}}$ conditions and $\sim 20-30 \%$ under high- $\mathrm{NO}_{\mathrm{x}}$ conditions (Chan et al., 2009). Because naphthalene and its derivatives composed up to $17 \%$ (CG) of total aromatic HCs, such compounds may be significant contributors to SOA mass in BB plumes (Chan et al., 2009).

\subsubsection{Oxygenated aromatic compounds}

Oxygenated aromatic compounds constituted between $3.8 \%$ (BS) and $17 \%$ (CG) of the total EF measured from each fuel. Phenol was the most abundant oxygenated aromatic species emitted for all of the fuels tested (Table A1). Several sub- stituted phenols were also identified, including methyl and dimethyl phenols. Phenolic compounds arise from the pyrolysis of lignin, an amorphous polyphenolic polymer (Pandey and Kim, 2011). Guaiacol was the only methoxy phenol detected in the cartridge samples (Table A1); however, several guaiacol derivatives were volatilized from the filter samples, primarily from the coniferous fuels (Table 2). Guaiacols are commonly measured in smoke from coniferous fuels (Jiang et al., 2010; Saiz-Jimenez and De Leeuw, 1986), as these softwoods contain lignins composed primarily of guaiacyl units (Shafizadeh, 1982). Several other non-phenolic oxygen-containing aromatic compounds were observed, including furans, aldehydes, ketones, and ethers (Table A1). Little information exists regarding the formation of such compounds in fires, although several have been previously 
(a)

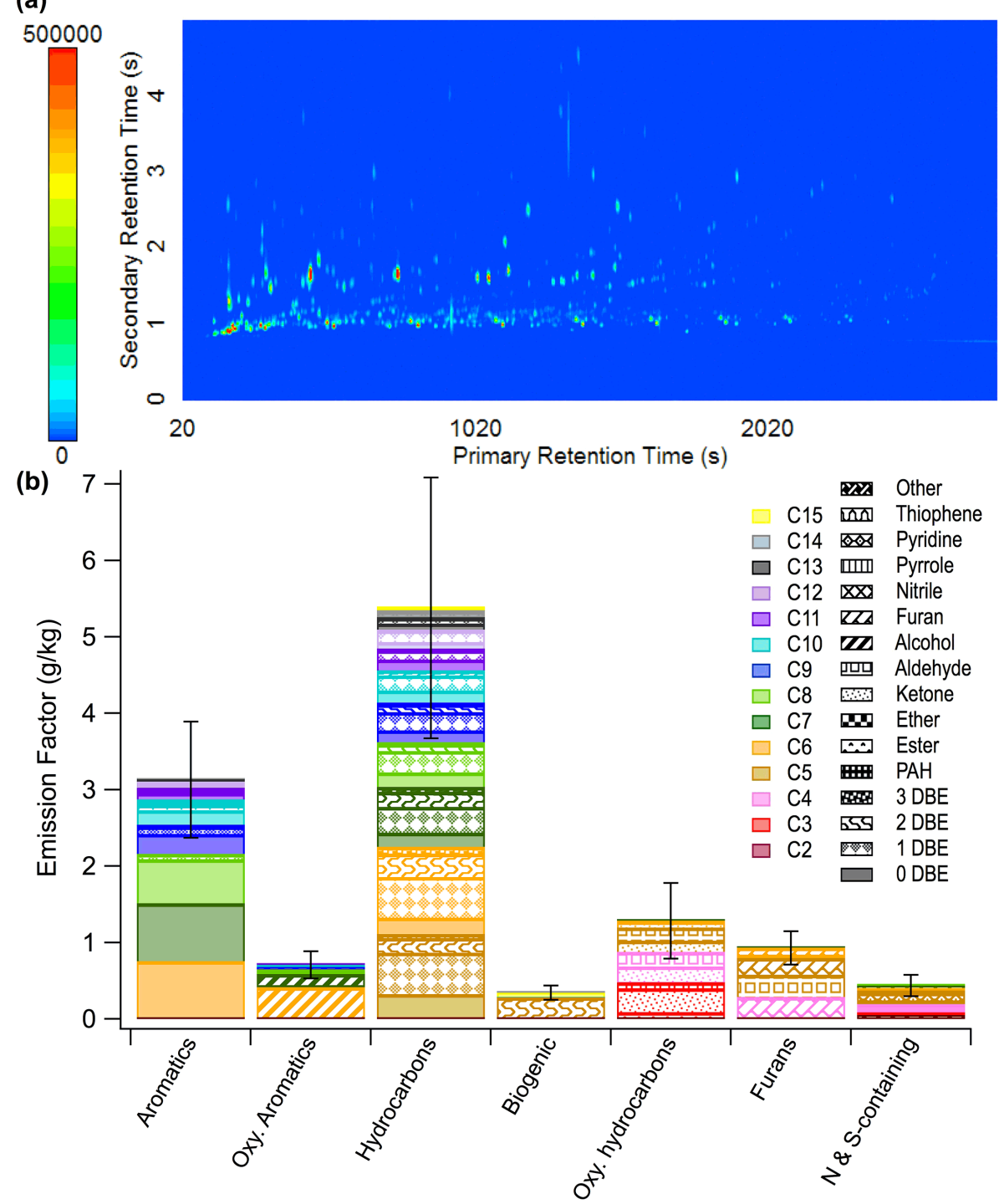

Figure 6. As in Fig. 1, for an Indonesian peat fire.

observed in BB smoke (Yokelson et al., 2013; Andreae and Merlet, 2001).

Phenol, alkyl phenols, and guaiacol have been shown to produce SOA in relatively high yields $(\sim 25-50 \%)$ from $\mathrm{OH}$-initiated gas-phase chemistry (Yee et al., 2013; Nakao et al., 2011). Recent work has also demonstrated nearly $100 \%$ SOA yield from aqueous-phase photochemical reactions of phenols (Smith et al., 2014; Sun et al., 2010). Given the dominance of phenols among the oxygenated aromatic compounds (Figs. 1-6) and their reportedly high-SOA yields, phenols are likely to be the most significant SOA precursors in this category. SOA formation from the less abundant oxygenated aromatic compounds (aldehydes, ketone, furans) has not been well characterized. However, benzaldehyde, acetophenone, and benzofuran (including its methyl derivatives) were present in the smoke from all six burns; these com- pounds may be good subjects for future smog chamber studies.

\subsubsection{Aliphatic hydrocarbons}

Approximately half of all detected compounds were aliphatic HCs, with 0-4 DBE. Up to $33 \%$ (IP) by EF of the aliphatic $\mathrm{HC}$ category is attributed to compounds larger than the $\leq \mathrm{C}_{8}$ compounds typically reported in BB emissions (Akagi et al., 2011; Andreae and Merlet, 2001). Few BB studies have measured $>\mathrm{C}_{9}$ aliphatic HCs. Ciccioli et al. (2001) detected up to $\mathrm{C}_{13}$ alkanes/alkenes from flaming and smoldering pine wood; Schauer et al. (2001) measured $\mathrm{C}_{1-9}$ and $\mathrm{C}_{18-24}$ alkanes in the gaseous emissions from pine wood burning, but they did not report the intermediate species. In four of the six FLAME-4 filter-desorption samples, tetradecane and pen- 


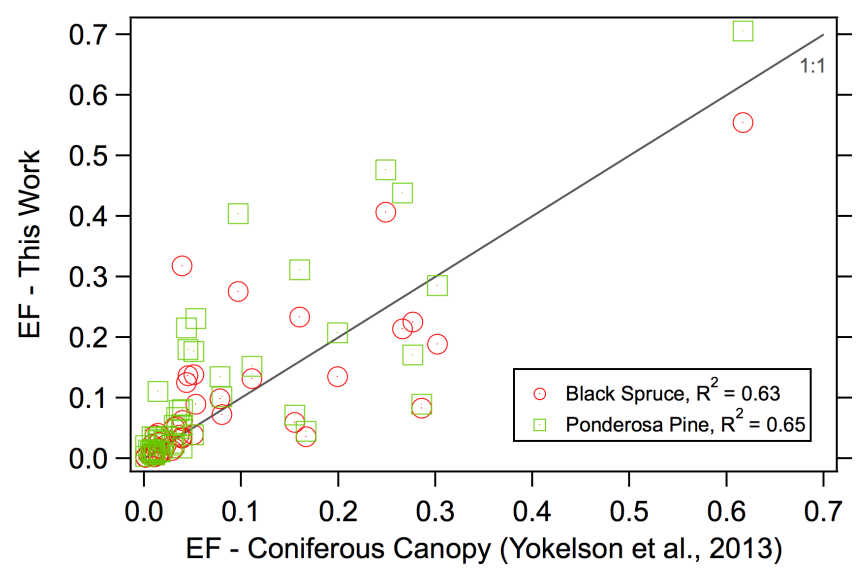

Figure 7. Comparison of the EFs measured for BS and PP, compared to the average of coniferous canopy burns given by Yokelson et al. (2013).

tadecane were observed (Table 2), suggesting that intermediate volatility compounds are often present in BB emissions. IP smoke contained the highest MW HCs of all burns with alkanes and 1-alkenes detected up to $\mathrm{C}_{18}$ (Tables $\mathrm{A} 1$ and 2). This is consistent with the relative MCEs (Table A1) because smoldering combustion tends to generate higher MW compounds (Lobert and Warnatz, 1993).

Aliphatic HCs were well separated according to DBE; thus, the relative contribution of saturated and unsaturated HCs can be readily assessed (Fig. 9). The CG fire emitted the highest fraction of unsaturated compounds, with only one alkane detected; conversely, IP combustion led predominantly to saturated alkanes (Fig. 9; Table A1). Emissions for the other four fuels fell between CG and IP smoke, with three to eight times higher levels of 1-DBE compounds than saturated compounds (Fig. 9). Of the 1-DBE compounds, the most abundant isomers were generally 1-alkenes; at $\geq \mathrm{C}_{13}$, 1 -alkenes were often the only unsaturated compounds detected (Tables A1 and 2).

Whereas the aliphatic $\mathrm{HC}$ emissions from most fuels were composed primarily of 1 - and 2-DBE compounds, 3-DBE compounds constituted the highest fraction of aliphatic HCs in the CG fire emissions (Fig. 9). This class was dominated by 1,3-cyclopentadiene and its methyl derivatives (Table A1). 1,3-cyclopentadiene may form via loss of CO from phenol (a product of lignin pyrolysis, as discussed in Sect. 3.3.2) and is thought to contribute to the formation of PAHs (e.g., naphthalene) and similar compounds (e.g., indene) during combustion (Fitzpatrick et al., 2008; Mulholland et al., 2000). This is consistent with the high relative contributions from phenolic compounds and PAHs in CG emissions (Fig. 3) and suggests that CG has high lignin content (discussed further in Sect. 3.3.6).

Much recent research has probed the SOA-formation potential of aliphatic $\mathrm{HCs}$ as a function of carbon number and structure. The SOA yield of alkanes increases dramat-

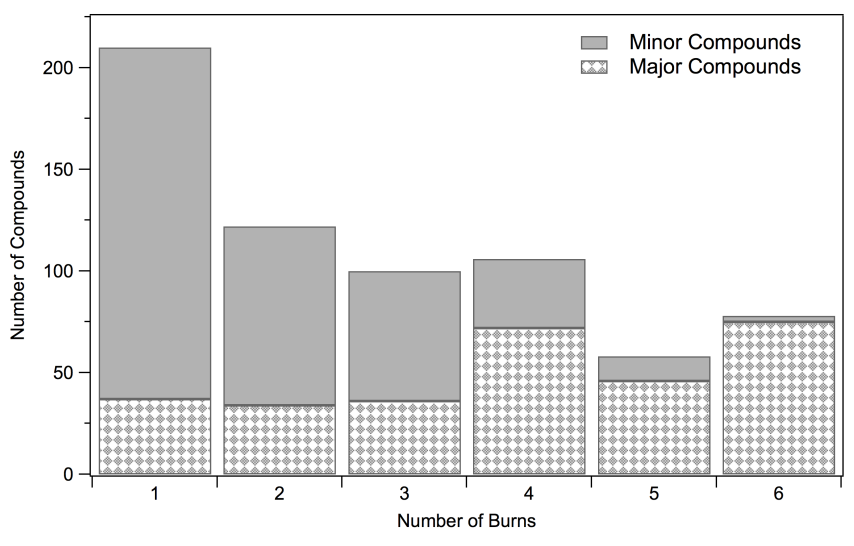

Figure 8. Histogram of the number of compounds present in the indicated number of burns. Compounds were considered major if the $\mathrm{EF}$ was $>0.01 \mathrm{~g} \mathrm{~kg}^{-1}$ in any burn. All other compounds were classified as minor.

ically with increasing carbon number - particularly for $>\mathrm{C}_{10}$ compounds (Lim and Ziemann, 2009); for example, yields of $\sim 50 \%$ (Presto et al., 2010) to $\sim 90 \%$ (Lim and Ziemann, 2009) have been reported for heptadecane in the presence of $\mathrm{NO}_{\mathrm{x}}$. Further, the SOA yields of linear alkanes are greater than branched alkanes (Ziemann, 2011). Unsaturated aliphatic $\mathrm{HCs}$ are more reactive toward $\mathrm{OH}$ and nitrate radical than alkanes, and are susceptible to reaction by ozone (Atkinson and Arey, 2003b). The SOA yields from 1-alkenes are $\sim 17-117 \%$ higher than alkanes up to $C_{13}$, at which point the yields of 1-alkenes plateau (Ziemann, 2011; Lim and Ziemann, 2009). Terminal alkenes exhibit 20-380\% higher SOA yields than internal alkenes, due to a greater propensity for the latter to fragment during oxidation (Ziemann and Atkinson, 2012; Matsunaga et al., 2009). The aliphatic $\mathrm{HC}$ isomers most likely to generate significant SOA (i.e., $n$-alkanes and 1-alkenes) were those predominantly observed in the sampled BB emissions: of the non-grass fuels (the grasses did not contain significant intermediate volatility aliphatic $\mathrm{HCs}$ ), the fraction (by EF) of linear alkanes $\left(\geq \mathrm{C}_{10}\right)$ ranged from $68 \%$ (IP) to $87 \%$ (BS) and the fraction of terminal alkenes $\left(\geq \mathrm{C}_{10}\right)$ varied from $59 \%$ (IP) to $93 \%$ (BS) (Table A1).

\subsubsection{Oxygenated aliphatic compounds}

The relative contributions of oxygenated aliphatic compounds to the measured total EF from each burn varied by fuel, from $\sim 10 \%$ for IP to $\sim 31 \%$ for WG and RS. For the compounds detected here, the dominant oxygenated compounds across all fuels were low-MW ketones and aldehydes (Figs. 1-6). These emissions include acyclic compounds, as well as many cyclopentenone derivatives, and cyclopentenedione isomers (Table A1). Such compounds can arise from the pyrolysis of glucose (Paine et al., 2008b). 


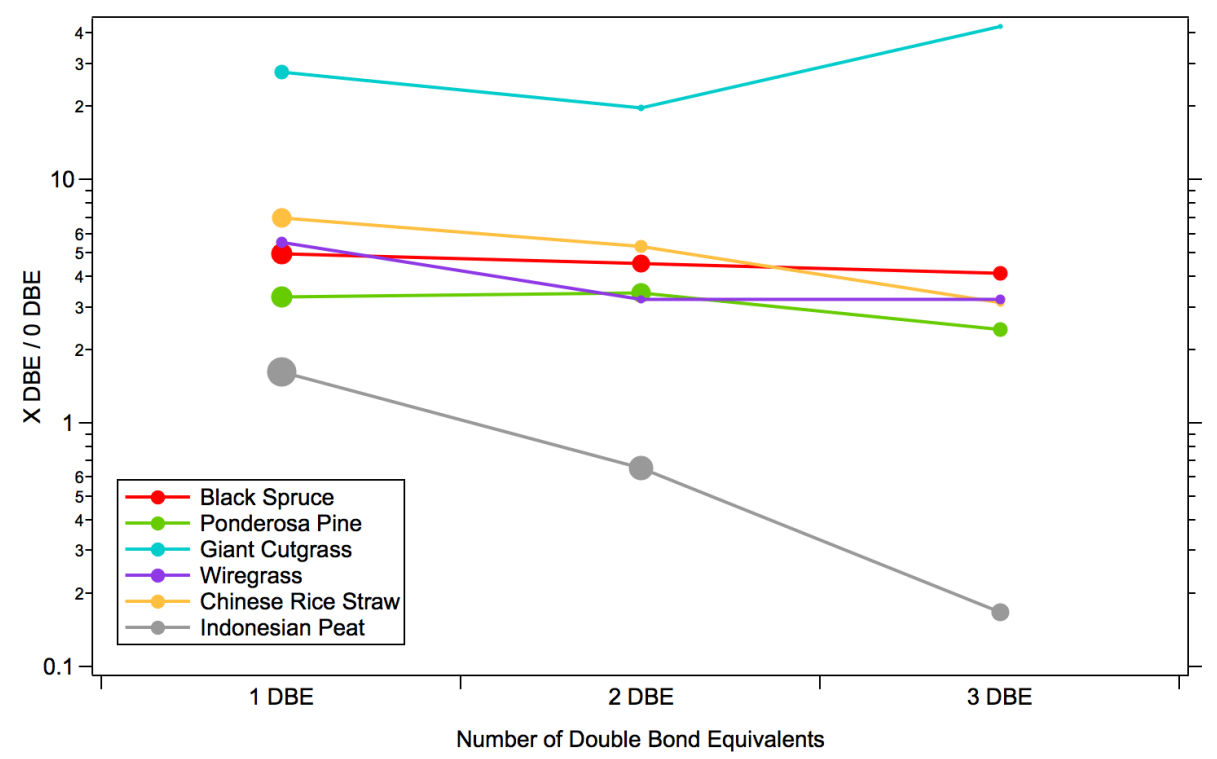

Figure 9. Ratio of the EFs for unsaturated aliphatic hydrocarbons (separated by double bond equivalents, DBE) vs. alkanes. The marker sizes are proportional to the average carbon number (from 5 to 8) at each DBE.

RS emissions were dominated by oxygenated compounds, which can be readily observed in Fig. 5 by the broad smearing of polar compounds along the secondary axis of the chromatogram. Interestingly, the RS sample had the highest ash content of all fuels tested (7.7\% vs. $1.5-3.8 \%$ by weight; Table A1). Pyrolysis experiments have demonstrated that ash can catalyze cellulose degradation leading to greater yields of several light-oxygenated compounds (Patwardhan et al., 2010; Eom et al., 2012, 2013), including hydroxyacetone whose EF is $\sim 10$-fold higher from RS than any other fuel (Table A1). Thus, the high ash content in RS may explain the preponderance of the light-oxygenated compounds in the $\mathrm{BB}$ emissions from this fuel.

Several of the identified ketones and aldehydes are known SOA precursors, such as methyl vinyl ketone (Chan et al., 2013; Liu et al., 2012) and methacrolein (Chan et al., 2010; Surratt et al., 2006). Methacrolein and other unsaturated aldehydes observed in the cartridge samples (e.g., 2-butenal; Table A1) have been shown in laboratory studies to produce SOA through peroxy acyl nitrate (PAN) intermediates, with SOA yields that increase with increasing $\mathrm{NO}_{2} / \mathrm{NO}$ ratios (Chan et al., 2010). At the $\mathrm{NO}_{2} / \mathrm{NO}$ EF ratios of $\sim 3.5-7$ reported for ambient BB (Akagi et al., 2013; Simpson et al., 2011) the SOA yield of methacrolein, for example, is $\sim 19$ $24 \%$ compared to $<3 \%$ under high-NO conditions (Chan et al., 2010). These observations suggest that unsaturated aldehydes have the potential to form significant SOA via the PAN pathway in BB smoke. Although the available SOA yields of oxygenated aliphatic compounds are generally relatively low $(<10 \%)$, the generated SOA mass may not be trivial in smoke plumes with a high fraction of oxygenated aliphatic compounds (e.g., as from RS).

\subsubsection{Terpenoids}

Figures $1 \mathrm{~b}$ and $2 \mathrm{~b}$ illustrate the significant levels of terpenoids detected in smoke from both coniferous fuels (BS, $27 \%$ and PP, $14 \%$ by EF). The relative contributions of terpenoids from the other fuels were small, and were dominated by isoprene. Isoprene was the only terpene detected in the smoke of all plant fuels sampled (Table A1). Detection of isoprene from burning peat and non-isoprene emitting plants such as RS (Kesselmeier and Staudt, 1999) indicates that isoprene is formed during combustion.

Terpenoids constituted the largest EF category in BS smoke, but only the fourth largest in PP (Figs. 1 and 2). The BS sample was cut a few days prior to burning and thus should have been representative of living BS trees. In contrast, the PP branches were cut approximately 1 month before the burn and included a mix of brown and green needles at the time of burning. The PP sample therefore represented a mix of forest floor litter and fresh, live branches. Some losses (e.g., through volatilization) of biogenic compounds likely occurred while storing the PP sample. A more rigorous comparison of the relative magnitudes of terpene emissions should ideally utilize branches of similar freshness. However, both fresh and aged needles (litter) can be important fuel components of fires in coniferous ecosystems (Stockwell et al., 2014; Yokelson et al., 2013); the data reported thus are useful for understanding the smoke from such fires.

In this study, 32 monoterpene (MT) isomers were detected in the smoke from each coniferous fire, of which 13 were positively identified (Table A1). Prior to this work, Ciccioli et al. (2001) presented the most comprehensive list of MTs 
from BB, reporting $14 \mathrm{MTs}$ during a laboratory burn of $\mathrm{Pi}$ nus pinea using GC-MS. In FLAME-4, the 10 most abundant MTs represented $\sim 90 \%$ of the total MT emissions for each coniferous fuel, including many of the compounds measured by Ciccioli et al. (2001). Consistency in the MT emissions from a given plant species is suggested by the similarity in the MT-isomer distribution from the BS fire emissions shown in Fig. 10 and a separate BS fire (see Fig. S2 in the Supplement). The relative proportions of the top $10 \mathrm{MT}$ isomers from each fuel are shown in Fig. 10, compared to those previously measured in the corresponding plant essential oils (Krauze-Baranowska et al., 2002; Anderson et al., 1969; von Rudloff, 1975). Camphene (3-carene) is the dominant MT isomer in BS needles (wood), whereas $\beta$-pinene (3-carene) is the dominant MT isomer in PP needles (wood) (Fig. 10). Although there is quite reasonable agreement between the MT composition of essential oils and the smoke samples from the coniferous fuels, the relative proportions of MTs in the smoke samples are not exact matches to the essential oils. First, the distribution of MTs differs considerably between the needle- and wood-derived essential oils of these conifers; for example, 3-carene is significantly higher in wood than needles (Fig. 10). The relative mass of needles vs. wood burned in these experiments was not measured, but visual observations indicated that needle combustion dominated (most of the needles burned, but much of the wood was only charred). This is consistent with the measured distribution of MT isomers in the needle and twig-derived essential oils (e.g., comparing camphene and 3-carene in BS smoke). Further, it is known that MTs can thermally isomerize during pyrolysis (Stolle et al., 2009 and references therein). In particular, myrcene and limonene are known thermal rearrangement products of $\beta$-pinene (Stolle et al., 2009). This may explain the lower relative concentration of $\beta$-pinene and higher relative proportions of myrcene and limonene in PP smoke compared to the MT distribution of needle and wood essential oils.

The similarities between the MTs in smoke and those in essential oils demonstrate that MT emissions from BB are plant specific. Because terpenes are essentially distilled out of storage reservoirs during fires (Yokelson et al., 1996), essential oils obtained by steam distillation are likely to be good proxies when predicting MT emissions from BB. For example, the BS essential oil data (von Rudloff, 1975) were also useful for confirming the identification of monoterpenoids detected in $\mathrm{BS}$ smoke, including bornyl acetate $\left(\mathrm{C}_{12} \mathrm{H}_{20} \mathrm{O}_{2}\right)$ and santene $\left(\mathrm{C}_{9} \mathrm{H}_{14}\right)$ (Table A1). Although only two coniferous fuels were examined in this work, the major MTs (limonene and $\alpha$-pinene) observed by Ciccioli et al. (2001) are also in agreement with the major constituents of Pinus pinea essential oil (Nasri et al., 2011). Although promising, the reproducibility of such similarities should be confirmed by testing a wider range of plant species and burn conditions.
Given the wide range of atmospheric reactivity and SOA yields among the MT isomers (Lee et al., 2006; Atkinson and Arey, 2003a), the variability in MT isomers emitted from different plant species could significantly impact BB SOA chemistry. The compounds included in Fig. 10 have been arranged in order of increasing SOA yields, based largely on Lee et al. (2006) for reaction with $\mathrm{OH}$. As discussed by Akagi et al. (2013), reaction with $\mathrm{OH}$ is likely the dominant MT oxidation pathway in smoke plumes. The SOA yield for reaction of camphene with $\mathrm{OH}$ has not been characterized; however, its SOA yield with ozone is reportedly negligible (Hatfield and Hartz, 2011). Tricyclene does not contain double bonds; its SOA-formation potential is assumed here to be the lowest of the MT isomers. Although $1.4 \times$ higher total MT EFs were observed for BS (Figs. 1 and 2), BS smoke contained predominantly low-SOA-yield MTs, whereas PPderived smoke contained higher SOA-yield MTs (Fig. 10). For comparison, Fig. 10 also includes the relative MT EFs for coniferous canopy fuels listed in Yokelson et al. (2013). The average coniferous canopy values do not adequately represent the distribution of either BS or PP, particularly the contributions of the high-SOA-yield species, such as limonene. More accurate model predictions of MT-derived SOA likely will be achieved with knowledge of the actual distribution of MT isomers emitted in BB smoke, which will vary among different plant species. At least for MTs, utilizing regional averages may not be sufficient for representing SOA formation in air quality and climate applications. Considering the wide range of reported SOA yields among the MT isomers (<10-60\%; Lee et al., 2006; Griffin et al., 1999), prediction errors may be significant considering the large contribution and distribution of these species in the smoke of coniferous fuels (Figs. 1 and 2). In the absence of speciated MT measurements, we propose that SOA models apply the MT distribution from needle-derived essential oils corresponding to the vegetation mix (if available) to yield more reliable results than assuming a single surrogate MT. In this regard, measured or modeled total MT EF could be distributed over the relative proportions of specific isomers reported for plantspecific steam-distilled essential oils.

Limited information has been reported regarding the speciation of sesquiterpenes (SQTs) in BB smoke. Ciccioli et al. (2001) detected four SQT isomers from burning Pinus pinea, but only aromadendrene was identified. Other reports of SQTs in BB smoke are typically derived from proton-transfer reaction mass spectrometry (PTR-MS) measurements (e.g., Yokelson et al., 2013), and thus do not provide structural information. SQTs have historically been difficult to measure (Pollmann et al., 2005; Bouvier-Brown et al., 2009) due to their relatively low volatilities ( $p_{\mathrm{L}}^{o}$ $\sim 1 \times 10^{-3} \mathrm{kPa}$ at $25^{\circ} \mathrm{C}$, Helmig et al., 2003) and high reactivities (atmospheric lifetimes on the order of minutes to hours, Atkinson and Arey, 2003a). In this work, efforts were made to minimize SQT-related sampling artifacts. Relevant to our sampling configuration, Helmig et al. (2004) found 


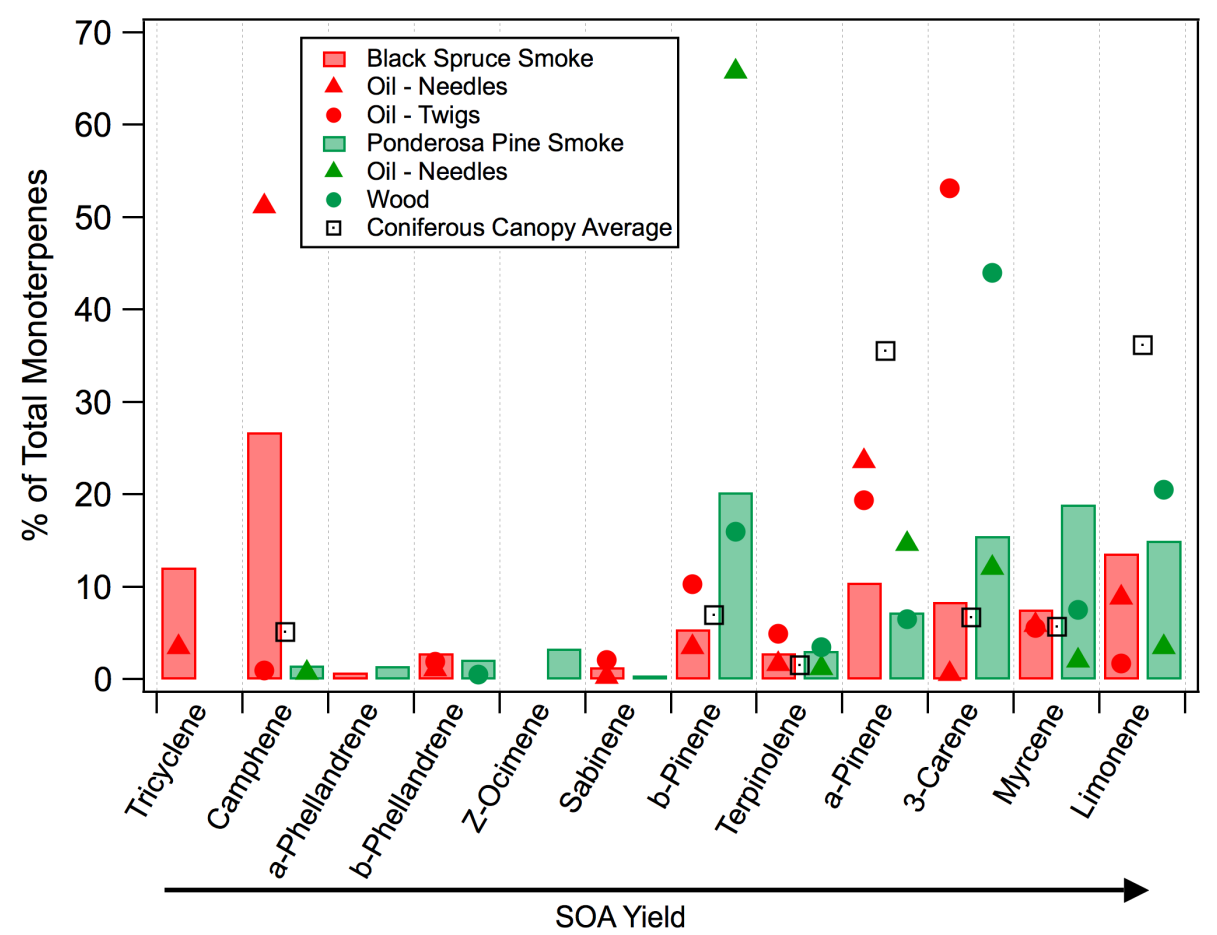

Figure 10. Distribution of the monoterpene isomers observed in smoke from fires of black spruce (BS) and ponderosa pine (PP), as a percentage of the total monoterpene EF. The compounds are sorted in order of increasing SOA yield, largely based on Lee et al. (2006). Colored markers represent the percentage of each monoterpene measured in the essential oils of BS needles and twigs (von Rudloff, 1975) and PP needles (Krauze-Baranowska et al., 2002) and wood (Anderson et al., 1969). Black squares indicate the MT emissions averaged over coniferous canopy fires reported in Yokelson et al. (2013). All literature values were converted to \% of reported monoterpenes.

high $(\sim 90 \%)$ recoveries for sesquiterpenes following nearly $4 \mathrm{~m}$ of Teflon tubing. Further, Pollmann et al. (2005) found no significant adsorption losses of SQTs to a thiosulfateimpregnated filter, as well as high recovery of all isomers from Tenax TA sorbent cartridges. Highly reactive SQTs may have been partially lost if ozone was not completely removed (Pollmann et al., 2005); however, that is unlikely given the near-zero ozone concentrations present in fresh BB smoke (Yokelson et al., 2003; Akagi et al., 2013) and the ozoneremoval efficiency of the sodium thiosulfate-impregnated filters (Sect. 2.1.2).

Eleven SQT isomers were detected in smoke from the coniferous fuels (Table A1). These $\mathrm{GC} \times \mathrm{GC}$ measurements therefore reflect the most comprehensive characterization of SQTs in BB smoke to date. No SQTs were found in smoke from the other fuels; however, the IP fire emitted SQT-like compounds with the formula $\mathrm{C}_{15} \mathrm{H}_{26}$ (Table A1). SQTs constituted a small fraction of the terpenes observed in both BS and PP (Figs. 1 and 2), consistent with the relatively low levels present in these essential oils (KrauzeBaranowska et al., 2002; von Rudloff, 1975). The majority of the observed SQTs are tentatively identified as isomers of cadinene, amorphene, and/or muurolene, which have the same bi-cyclic cadalane skeleton and differ only in the position of the two double bonds and stereochemistry; these compounds are labelled as cadinene isomers in Table A1. Cadinene isomers have been previously detected in the essential oils of BS (von Rudloff, 1975) and PP (KrauzeBaranowska et al., 2002). Other tentatively identified compounds with a cadalane backbone were also observed, including copaene $\left(\mathrm{C}_{15} \mathrm{H}_{24}\right)$, calamenene $\left(\mathrm{C}_{15} \mathrm{H}_{22}\right)$, and calacorene $\left(\mathrm{C}_{15} \mathrm{H}_{20}\right)$ (Table A1). Cadinenes have received comparatively little study in terms of atmospheric reactivity; however, other SQT isomers are known to have high SOA yields (Lee et al., 2006).

\subsubsection{Furans}

Although furans are oxygenated aromatic species, a separate class was created since they constituted a significant fraction $(5-37 \%$ by EF) of the smoke from each fuel tested (Figs. 1-6). Furans arise primarily from the breakdown and dehydration of cellulose (Paine et al., 2008a). Compounds in this group generally contained 4-6 carbons with alkyl and/or oxygenated substituents, most commonly as aldehyde or alcohol moieties (Table A1). Furan emissions were generally dominated by furan and furfural, with significant contributions from 2-methyl furan and 2-furanmethanol (Figs. 1-6; Table A1). 
WG smoke contained the highest relative furan contribution (37\% by EF; Fig. 4). Furfural was the dominant species emitted from this fuel within the range of analyzed compounds (Table A1). In contrast, CG combustion emitted largely benzene and naphthalene derivatives (Fig. 3). The variation in emissions could indicate substantial differences in the structure of these grasses: the high levels of furans detected in WG smoke suggest high levels of cellulose in the plant material, whereas the preponderance of aromatic compounds, including phenols, in CG smoke suggest high lignin content as discussed above (Sect. 3.3.3). Although the biomass composition of these grasses has not been reported, this hypothesis is consistent with the structures of these plants. Giant CG is characterized by tall, wide, and stiff leaves (USDA, 2014) that likely require higher lignin content for support. In comparison, WG is short, wiry, and pliable (USDA, 2014). The MCEs were quite different for these two burns (0.925 for CG vs. 0.97 for WG) and thus combustion conditions may also have influenced the emitted compounds.

Furans are highly reactive, with atmospheric lifetimes on the order of several hours with respect to $\mathrm{OH}$ oxidation (Bierbach et al., 1992). Although the kinetics of furfural oxidation have been characterized (Colmenar et al., 2012; Bierbach et al., 1995), product studies have not yet been conducted, thereby limiting assessment of its SOA-formation potential. Gas-phase photochemistry of alkyl furans has been more extensively studied (Alvarado et al., 1996; Aschmann et al., 2011; Bierbach et al., 1992; Gómez Alvarez et al., 2009) and generally proceeds via $\mathrm{OH}$-radical addition to the aromatic ring with subsequent ring opening (Bierbach et al., 1995). The major identified products are unsaturated 1,4dicarbonyls, with yields that decrease with increasing number of alkyl substituents (Aschmann et al., 2014). Strollo and Ziemann (2013) found that these first-generation reaction products of 3-methyl furan can undergo acid-catalyzed condensed-phase oligomerization reactions, with SOA yields up to $15 \%$. Given that aldehydes are more likely to oligomerize than ketones (Strollo and Ziemann, 2013), furan and 3-methyl furan will likely produce the highest SOA yields by this mechanism since their predominant first generation products are unsaturated dialdehydes (Aschmann et al., 2014). These unsaturated aldehydes may also react through a PAN channel, as discussed in Sect. 3.3.4. Given the high levels of furans detected in these smoke samples, it is important to elucidate the potential SOA-formation pathways of these compounds and their role in SOA production in BB plumes.

\subsubsection{Nitrogen- and sulfur-containing compounds}

Emissions of $\mathrm{N}$ - and S-containing compounds are generally proportional to the nitrogen and sulfur content of the fuel biomass (Ward, 1990). Consistent with the relative nitrogen content in the fuels (Table A1), CG smoke had the highest relative contribution from $\mathrm{N}$-containing species: $11 \%$ vs. $\sim 2-6 \%$ from the other fuels. The predominant emitted $\mathrm{N}$ species from CG combustion were nitriles that arise from the pyrolysis of amino acids (Lobert and Warnatz, 1993). Interestingly, the predominant $\mathrm{N}$-containing species from most other fuels were pyrroles rather than nitriles. However, acetonitrile was likely underestimated by our measurements due to high breakthrough. Extensive N-heterocyclic compounds have also been observed in PM samples from burns of RS (Ma and Hays, 2008) and PP (Laskin et al., 2009), consistent with the observations herein. The SOA-formation potentials of pyrroles and nitriles have not been elucidated. However, due to the small molecular sizes $\left(<\mathrm{C}_{7}\right)$ and relatively low concentrations of the observed compounds $(\sim 2-11 \%$ of the total $\mathrm{EF}$ ), they are not likely to contribute significantly to BB SOA.

Sulfur is an important nutrient for plant function. As discussed by Ward (1990), sulfur in ecosystems can only be replenished through deposition; thus, local losses of sulfur due to fire activity can influence land sustainability and sulfur transport. Dimethyl sulfide (DMS) and dimethyl disulfide are the predominant organosulfur compounds that have been reported in BB smoke to date (Akagi et al., 2011; Simpson et al., 2011; Friedli et al., 2001; Meinardi et al., 2003). Thiophene - the sulfur analog to furan - and its derivatives were detected in five of the fuels tested. Ciccioli et al. (2001) have previously identified thiophene in BB emissions; however, they do not report an EF. In this work, the thiophene $\mathrm{EF}$ has been quantified, along with its methyl derivatives and benzo(a)thiophene (Table A1). The reported thiophene EFs are comparable to the EFs commonly reported for DMS (Akagi et al., 2011; Simpson et al., 2011); therefore, thiophenes may be important organosulfur species in BB emissions. (Dimethyl disulfide was detected at trace levels in the RS burn, but was not quantified due to lack of a suitable standard compound.) Rate constants for reactions of thiophene with atmospheric oxidants have been measured (Atkinson et al., 1983; Cabañas et al., 2005), and are generally lower than for the corresponding furan reactions due to greater aromaticity of the thiophene ring compared to furan (Bierbach et al., 1992); SOA yields are unknown.

\section{Conclusions}

This work represents the first application of $\mathrm{GC} \times \mathrm{GC}-$ ToFMS for the broad characterization of NMOCs from BB. Utilizing the approach described herein, 708 total compounds in the $\mathrm{C}_{2}-\mathrm{C}_{18}$ range were speciated, including the cartridge and filter-desorption samples, demonstrating the extensive capability of GC $\times$ GC-ToFMS to facilitate identification and quantification of $\mathrm{BB}$ emissions. Although the ability to reliably quantify analytes present at very high concentrations (e.g., benzene) was hindered due to limited dynamic range, newer model ATD instruments permit trapping of the unused portion of each sample, thereby enabling multiple analyses of each cartridge sample. In particular, appli- 
Table 3. Calculated SOA mass (as $\mathrm{g} \mathrm{kg}^{-1}$ fuel burned) produced from the measured precursors in each chemical class after $6 \mathrm{~h}$ of oxidation (at $[\mathrm{OH}]=2 \times 10^{6}$ molecules $\mathrm{cm}^{-3}$ ) using representative rate constants. The values in parentheses reflect the estimated SOA mass assuming $100 \%$ reaction of all compounds in each class.

\begin{tabular}{lrrrrrr}
\hline Category & Black spruce & Pond. pine & Cutgrass & Wiregrass & Rice straw & Ind. peat \\
\hline Aromatic HCs $^{\mathrm{a}}$ & $0.18(0.63)$ & $0.21(0.77)$ & $0.08(0.22)$ & $0.01(0.04)$ & $0.05(0.18)$ & $0.31(1.19)$ \\
Phenols $^{\mathrm{b}}$ & $0.03(0.04)$ & $0.11(0.16)$ & $0.03(0.04)$ & $0.02(0.02)$ & $0.06(0.09)$ & $0.11(0.16)$ \\
Aliphatic HCs $^{\mathrm{c}}$ & $0.05(0.05)$ & $0.09(0.11)$ & $0.001(0.001)$ & $0.00(0.00)$ & $0.01(0.01)$ & $0.47(0.61)$ \\
Oxy. aliphatics $^{\mathrm{d}}$ & $0.02(0.06)$ & $0.04(0.11)$ & $0.003(0.009)$ & $0.01(0.02)$ & $0.02(0.05)$ & $0.03(0.08)$ \\
Terpenes $^{\mathrm{e}}$ & $0.47(0.51)$ & $0.42(0.43)$ & $0.001(0.001)$ & $0.001(0.001)$ & $0.01(0.01)$ & $0.009(0.009)$ \\
Furans $^{\mathrm{f}}$ & $0.07(0.08)$ & $0.13(0.14)$ & $0.01(0.01)$ & $0.04(0.04)$ & $0.06(0.06)$ & $0.10(0.11)$ \\
\hline Total potential SOA & $0.81(1.37)$ & $0.99(1.70)$ & $0.12(0.29)$ & $0.08(0.12)$ & $0.21(0.40)$ & $1.01(2.15)$ \\
Typical POA EF & 9.92 & 28.16 & 4.16 & 5.6 & 9.92 & 9.92 \\
OA enhancement ratio $^{\mathrm{g}}$ & $1.08(1.14)$ & $1.04(1.06)$ & $1.03(1.07)$ & $1.01(1.02)$ & $1.02(1.04)$ & $1.10(1.22)$ \\
\hline
\end{tabular}

Assumed rate constants and SOA yields:

${ }^{a}$ Benzene derivatives: $\mathrm{k}(\mathrm{OH})=5.63 \times 10^{-12} \mathrm{~cm}^{3}$ molecule $\mathrm{s}^{-1} \mathrm{~s}^{-1}$ (toluene; Atkinson and Arey, 2003a), SOA yield =0.3 ( $\mathrm{Ng}$ et al., 2007 ); naphthalene derivatives: $\mathrm{k}(\mathrm{OH})=23 \times 10^{-12} \mathrm{~cm}^{3}$ molecule $\mathrm{s}^{-1} \mathrm{~s}^{-1}$ (naphthalene; Atkinson and Arey, 2003a), SOA yield =0.7 (Chan et al., 2009).

${ }^{\mathrm{b}} \mathrm{k}(\mathrm{OH})=27 \times 10^{-12} \mathrm{~cm}^{3}$ molecule $\mathrm{e}^{-1} \mathrm{~s}^{-1}$, SOA yield $=0.25$ (Yee et al., 2013).

c Alkanes: $\mathrm{C}_{\mathrm{n}}$-dependent $\mathrm{k}(\mathrm{OH})$ values and SOA yields from Atkinson and Arey (2003a) and Lim and Ziemann (2009), respectively; alkenes: $\mathrm{C}_{\mathrm{n}}$-dependent values from Atkinson and Arey (2003a) and Matsunaga et al. (2009).

${ }^{\mathrm{d}} \mathrm{k}(\mathrm{OH})=10 \times 10^{-12} \mathrm{~cm}^{3}$ molecule ${ }^{-1} \mathrm{~s}^{-1}$ (average of propanal and acetone; Atkinson and Arey, 2003a), SOA yield $=0.05$ based on methacrolein and methyl vinyl ketone (Liu et al., 2012).

e MTs: Isomer-specific k(OH) values from Atkinson and Arey (2003a); SOA yields from Lee et al. (2006), yields for all other MT isomers assumed to be 0.15 . SQT rate constant and yield estimated at $200 \times 10^{-12} \mathrm{~cm}^{3}$ molecule ${ }^{-1} \mathrm{~s}^{-1}$ (Atkinson and Arey, 2003a) and 0.65 (Lee et al., 2006 ), respectively.

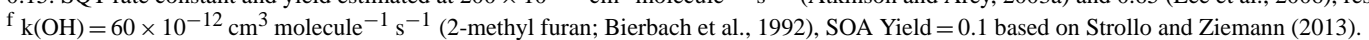

$\mathrm{g}$ Fuel-specific organic carbon EFs reported in McMeeking et al. (2009) for BS, PP, WG, and RS; the average OC EF from savannah and peatland fuels for

CG and IP, respectively (Akagi et al., 2011). The OC EFs were scaled to OA by the factor of 1.6 based on measured BB OM / OC ratios (Aiken et al., 2008).

cation of different $\mathrm{GC} \times \mathrm{GC}$ inlet split ratios would extend the range of quantitation and different column sets could be used to target more or less polar species. Further, alternative sorbent beds could be utilized for ATD cartridge sampling to target different volatility ranges, as desired (Pankow et al., 1998, 2012). This method is highly complementary to the other instrumentation commonly utilized for NMOC determinations. PTR-MS can measure some polar species not amenable to analysis by GC and in real time, but is limited in the area of compound identification due to the sole reliance on mass-to-charge ratio. In contrast, canister sampling with 1-D GC analysis is ideal for compounds that breakthrough ATD cartridges, but 1-D GC cannot separate a large number of compounds. All of these approaches, in addition to OP-FTIR, were utilized during FLAME-4 (Stockwell et al., 2014) and the measurements are being synthesized for publication in a separate manuscript.

The 708 compounds positively/tentatively identified across six laboratory burns have afforded unique insights into gas-phase BB emissions. In particular, the identified compounds can be related to the plant composition in a number of ways. The high levels of aromatic hydrocarbons and cyclopentadienes in giant-CG smoke imply high lignin content in this grass species compared to WG, which appears to be more cellulosic in structure based on the high furan emissions. Additionally, the thorough characterization of terpenoids emitted by burning conifer branches allow direct correlations to be made between $\mathrm{BB}$ emissions and the corresponding essential oils, underscoring that emissions of terpenoid isomers will be specific to individual plant species/fuel types. These measurements have also provided the first comprehensive characterization of intermediate volatility alkanes/alkenes in $\mathrm{BB}$, with compounds up to $\mathrm{C}_{15}$ present in most smoke samples and as high as $\mathrm{C}_{18}$ in the case of the IP fire. Separation of hydrocarbons by DBE further illustrated a high degree of unsaturation among aliphatic compounds, which will be highly reactive toward atmospheric oxidants. Overall, the distribution of emissions among different compound classes was found to vary considerably from fuel to fuel, indicating that the dominant reaction pathways in aging plumes will be highly dependent on the burned fuel types.

These comprehensive measurements have elucidated a large number of potential SOA precursors in BB emissions, including abundant isomers of aliphatic and aromatic hydrocarbons, phenol derivatives, monoterpenes, and sesquiterpenes. To estimate the relative importance of different precursor classes, the potential SOA mass from each category has been calculated using published SOA yields. Regarding the extent of NMOC oxidation, we have assumed two cases: (1) $6 \mathrm{~h}$ of oxidation and representative $\mathrm{OH}$ reactivity for each class and (2) all precursors react completely (Table 3 ). In comparing cases 1 and 2, it is clear that the phenol, aliphatic $\mathrm{HC}$, terpene, and furan classes react to (near) completion after only $6 \mathrm{~h}$ at $[\mathrm{OH}]=2 \times 10^{6}$ molecules $\mathrm{cm}^{-3}$ (Table 3 ). After $6 \mathrm{~h}$, terpenes emitted from coniferous fuels are expected to 
contribute significantly to SOA and account for 42 and $57 \%$ of the calculated SOA mass for PP and BS, respectively. SOA produced from aliphatic hydrocarbons was assumed to result from $\geq \mathrm{C}_{9}$ compounds only; the calculated SOA was significant for IP BB emissions alone due to the higher molecular weight alkanes/alkenes observed in this sample (Sect. 3.3.3). In addition to these common SOA precursors, recent research has demonstrated the potential for furans to contribute to SOA formation (Strollo and Ziemann, 2013), indicating that furans may be a previously unconsidered class of SOA precursors in BB smoke. We have assumed $10 \%$ SOA yields for all furan derivatives, based on the measured SOA yield of 3methyl furan (Strollo and Ziemann, 2013). At this SOA yield, furans may produce non-trivial SOA mass, including $51 \%$ of the SOA calculated from WG emissions after $6 \mathrm{~h}$ (Table 3 ). However, because the SOA-formation potential of furfural (the dominant furan derivative in $\mathrm{BB}$ ) has not been studied, it is unclear if the predicted furan-derived SOA is significantly over or underestimated. At longer oxidation times, SOA derived from aromatic hydrocarbons becomes significant. For all fuels, aromatic hydrocarbons are predicted to produce the largest fraction of SOA, ranging from $31 \%(\mathrm{WG})$ to $78 \%$ (CG) when all NMOC has reacted (Table 3). Overall, the identified SOA precursors produce estimated OA enhancement ratios on the order of 1.01-1.22, depending on the extent of NMOC oxidation. These estimates are in the range of that reported for laboratory experiments (Hennigan et al., 2011; Ortega et al., 2013) and ambient BB plumes (Akagi et al., 2012; Yokelson et al., 2009), though likely reflect a lower limit based on detected compounds. Because BB dominates global fine POA emissions, even modest enhancements can represent significant production of OA mass.
Despite the range of possible SOA precursors, most atmospheric models treat SOA formation through condensation of surrogates representing the gas-phase oxidation products of a very small number of NMOCs, which typically include benzene, toluene, xylenes, and select biogenic compounds (Carlton et al., 2010; Kanakidou et al., 2005; Odum et al., 1996). Such simplified representations cannot adequately capture the diversity in emissions and plume chemistry that is to be expected based on these GC $\times$ GC-ToFMS measurements and other recent efforts (Yokelson et al., 2013). Indeed, recent modeling studies were unable to recreate measured OA levels in BB plumes or BB-influenced regions (Alvarado et al., 2009; Heald et al., 2011), demonstrating that additional precursors and/or formation mechanisms need to be considered. These comprehensive GC $\times$ GC-ToFMS emissions measurements provide a significant step in that direction by identifying and quantifying a large number of potential SOA precursors. The reported EFs can further supplement existing BB emission inventories (van der Werf et al., 2010; Wiedinmyer et al., 2011; Akagi et al., 2011) that provide the input for atmospheric BB models; the data are available in Table S1. Although computational limits will preclude describing the chemistry of $700+$ primary species for the foreseeable future, a subset of the major, ubiquitous species determined herein can serve to focus future modeling efforts. 


\section{Appendix A}

Table A1. EF for all compounds detected in the cartridge samples. Compounds in bold were positively identified. Values in italics reflect measurements that are likely underestimated.

\begin{tabular}{|c|c|c|c|c|c|c|c|c|c|}
\hline \multirow[t]{2}{*}{ Compound } & \multirow[t]{2}{*}{ Formula } & \multirow{2}{*}{$\begin{array}{l}\text { Prim. } \\
\text { RT (s) }\end{array}$} & \multirow{2}{*}{$\begin{array}{r}\text { Sec. } \\
\text { RT (s) }\end{array}$} & \multicolumn{6}{|c|}{ Emission factors $\left(\mathrm{g} \mathrm{kg}^{-1}\right)$} \\
\hline & & & & Black spruce & Ponderosa pine & Giant cutgrass & Wire grass & Rice straw & Indonesian peat \\
\hline \multicolumn{10}{|l|}{ Burn and fuel characteristics } \\
\hline Burn number & & & & 156 & 144 & 148 & 151 & 153 & 154 \\
\hline MCE & & & & 0.933 & 0.927 & 0.925 & 0.970 & 0.942 & 0.832 \\
\hline Carbon (wt. \%) & & & & 50.5 & 51.11 & 44.84 & 46.7 & 42.07 & 59.71 \\
\hline Hydrogen (wt. \%) & & & & 6.37 & 6.64 & 6.1 & 6.32 & 5.68 & 5.01 \\
\hline Nitrogen (wt. \%) & & & & 0.66 & 1.09 & 2.03 & 0.61 & 1.3 & 2.28 \\
\hline Sulfur (wt. \%) & & & & 0.054 & NA & 0.207 & NA & 0.212 & 0.119 \\
\hline Ash (wt. \%) & & & & 3.8 & 1.5 & 2.3 & NA & 7.7 & 3.8 \\
\hline \multicolumn{10}{|l|}{ Aromatic hydrocarbons } \\
\hline \multicolumn{10}{|l|}{0 DBE (of substituents) } \\
\hline Benzene & $\mathrm{C}_{6} \mathrm{H}_{6}$ & 454.861 & 1.672 & $0.55 \pm 0.11$ & $0.71 \pm 0.14$ & $0.27 \pm 0.05$ & $0.031 \pm 0.008$ & $0.14 \pm 0.03$ & $0.88 \pm 0.18$ \\
\hline Toluene & $\mathrm{C}_{7} \mathrm{H}_{8}$ & 754.765 & 1.672 & $0.41 \pm 0.08$ & $0.48 \pm 0.1$ & $0.098 \pm 0.02$ & $0.028 \pm 0.006$ & $0.14 \pm 0.03$ & $0.90 \pm 0.18$ \\
\hline Ethylbenzene & $\mathrm{C}_{8} \mathrm{H}_{10}$ & 1024.68 & 1.628 & $0.063 \pm 0.031$ & $0.080 \pm 0.016$ & $0.011 \pm 0.002$ & $(3.9 \pm 1.7) \times 10^{-3}$ & $0.019 \pm 0.004$ & $0.15 \pm 0.03$ \\
\hline m- and p-Xylene & $\mathrm{C}_{8} \mathrm{H}_{10}$ & 1064.67 & 1.619 & $0.13 \pm 0.03$ & $0.15 \pm 0.03$ & $0.012 \pm 0.003$ & $(6.6 \pm 3.6) \times 10^{-3}$ & $0.035 \pm 0.007$ & $0.35 \pm 0.07$ \\
\hline o-Xylene & $\mathrm{C}_{8} \mathrm{H}_{10}$ & 1129.64 & 1.72 & $0.051 \pm 0.01$ & $0.055 \pm 0.011$ & $(3.1 \pm 1.5) \times 10^{-3}$ & - & $0.015 \pm 0.003$ & $0.18 \pm 0.04$ \\
\hline Benzene, isopropyl- & $\mathrm{C}_{9} \mathrm{H}_{12}$ & 1199.62 & 1.544 & $(9.1 \pm 1.8) \times 10^{-3}$ & $(8.4 \pm 1.7) \times 10^{-3}$ & $(5.9 \pm 1.4) \times 10^{-4}$ & - & $(7.9 \pm 1.6) \times 10^{-4}$ & $(4.9 \pm 1.3) \times 10^{-3}$ \\
\hline Benzene, propyl- & $\mathrm{C}_{9} \mathrm{H}_{12}$ & 1284.6 & 1.566 & $(9.3 \pm 2.2) \times 10^{-3}$ & $0.012 \pm 0.002$ & - & - & $(2.1 \pm 0.6) \times 10^{-3}$ & $0.044 \pm 0.009$ \\
\hline Benzene, 1-ethyl-(3+4)-methyl- & $\mathrm{C}_{9} \mathrm{H}_{12}$ & 1309.59 & 1.588 & $0.034 \pm 0.007$ & $0.040 \pm 0.008$ & $(1.9 \pm 0.6) \times 10^{-3}$ & $(1.1 \pm 0.9) \times 10^{-3}$ & $(9.0 \pm 1.8) \times 10^{-3}$ & $0.063 \pm 0.013$ \\
\hline Benzene, 1,3,5-trimethyl- & $\mathrm{C}_{9} \mathrm{H}_{12}$ & 1349.57 & 1.602 & $(4.8 \pm 1.7) \times 10^{-3}$ & $(7.8 \pm 2.0) \times 10^{-3}$ & - & - & $(2.3 \pm 0.6) \times 10^{-3}$ & $0.017 \pm 0.006$ \\
\hline Benzene, 1-ethyl-2-methyl- & $\mathrm{C}_{9} \mathrm{H}_{12}$ & 1364.57 & 1.65 & $0.012 \pm 0.002$ & $0.015 \pm 0.003$ & $(6.7 \pm 2.1) \times 10^{-4}$ & - & $(2.9 \pm 0.6) \times 10^{-3}$ & $0.048 \pm 0.01$ \\
\hline Benzene, 1,2,4-trimethyl- & $\mathrm{C}_{9} \mathrm{H}_{12}$ & 1419.55 & 1.65 & $0.012 \pm 0.002$ & $0.018 \pm 0.004$ & $(8.4 \pm 2.5) \times 10^{-4}$ & $(7.0 \pm 3.7) \times 10^{-4}$ & $(5.9 \pm 1.2) \times 10^{-3}$ & $0.076 \pm 0.015$ \\
\hline Benzene, 1,2,3-trimethyl- & $\mathrm{C}_{9} \mathrm{H}_{12}$ & 1494.53 & 1.76 & $0.017 \pm 0.003$ & $0.024 \pm 0.005$ & - & - & $(3.1 \pm 0.6) \times 10^{-3}$ & $0.060 \pm 0.012$ \\
\hline Isobutylbenzene & $\mathrm{C}_{10} \mathrm{H}_{14}$ & 1429.55 & 1.487 & $(2.3 \pm 0.5) \times 10^{-3}$ & - & - & - & - & $(6.5 \pm 1.3) \times 10^{-3}$ \\
\hline m-Cymene & $\mathrm{C}_{10} \mathrm{H}_{14}$ & 1464.54 & 1.509 & $(7.7 \pm 1.5) \times 10^{-3}$ & $0.012 \pm 0.002$ & - & - & $(6.1 \pm 1.2) \times 10^{-4}$ & $(6.1 \pm 1.2) \times 10^{-3}$ \\
\hline p-Cymene & $\mathrm{C}_{10} \mathrm{H}_{14}$ & 1474.53 & 1.514 & $0.039 \pm 0.008$ & $0.039 \pm 0.008$ & - & - & $(8.4 \pm 3.6) \times 10^{-4}$ & $0.023 \pm 0.005$ \\
\hline o-Cymene & $\mathrm{C}_{10} \mathrm{H}_{14}$ & 1509.52 & 1.566 & $(1.4 \pm 0.3) \times 10^{-3}$ & - & - & - & $(0.7 \pm 0.0) \times 10$ & 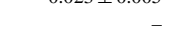 \\
\hline Benzene, 1,4-diethyl- & $\mathrm{C}_{10} \mathrm{H}_{14}$ & 1534.52 & 1.527 & $(1.8 \pm 0.9) \times 10^{-3}$ & $(2.7 \pm 1.3) \times 10^{-3}$ & - & - & $(5.8 \pm 2.9) \times 10^{-4}$ & - \\
\hline Benzene, 1-methyl-3-propyl- & $\mathrm{C}_{10} \mathrm{H}_{14}$ & 1544.51 & 1.527 & $(3.0 \pm 0.6) \times 10^{-3}$ & $(4.3 \pm 0.9) \times 10^{-3}$ & - & - & $(1.0 \pm 0.2) \times 10^{-3}$ & $0.015 \pm 0.003$ \\
\hline Benzene, 1-methyl-4-propyl- & $\mathrm{C}_{10} \mathrm{H}_{14}$ & 1554.51 & 1.536 & $(2.4 \pm 0.5) \times 10^{-3}$ & $(3.1 \pm 0.6) \times 10^{-3}$ & - & - & $(6.7 \pm 1.3) \times 10^{-4}$ & $0.011 \pm 0.002$ \\
\hline Benzene, butyl- & $\mathrm{C}_{10} \mathrm{H}_{14}$ & 1554.51 & 1.549 & $(6.6 \pm 1.3) \times 10^{-3}$ & $(9.2 \pm 1.8) \times 10^{-3}$ & - & - & $(1.2 \pm 0.2) \times 10^{-3}$ & $0.029 \pm 0.006$ \\
\hline Benzene, 5-ethyl-1,3-dimethyl- & $\mathrm{C}_{10} \mathrm{H}_{14}$ & 1569.5 & 1.558 & $(3.2 \pm 0.6) \times 10^{-3}$ & $(3.7 \pm 0.7) \times 10^{-3}$ & - & - & $(1.1 \pm 0.2) \times 10^{-3}$ & $(9.7 \pm 2.1) \times 10^{-3}$ \\
\hline Benzene, 1-methyl-2-propyl- & $\mathrm{C}_{10} \mathrm{H}_{14}$ & 1589.5 & 1.584 & $(3.0 \pm 0.7) \times 10^{-3}$ & $(4.6 \pm 0.9) \times 10^{-3}$ & - & - & $(6.9 \pm 1.9) \times 10^{-4}$ & $0.021 \pm 0.004$ \\
\hline Benzene, 2-ethyl-1,4-dimethyl- & $\mathrm{C}_{10} \mathrm{H}_{14}$ & 1619.49 & 1.593 & $(2.2 \pm 0.8) \times 10^{-3}$ & $(3.1 \pm 1.0) \times 10^{-3}$ & - & - & $(7.9 \pm 2.1) \times 10^{-3}$ & $0.010 \pm 0.003$ \\
\hline 1,3-Dimethyl-4-ethylbenzene & $\mathrm{C}_{10} \mathrm{H}_{14}$ & 1629.48 & 1.606 & $(3.4 \pm 0.7) \times 10^{-3}$ & $(4.8 \pm 1.0) \times 10^{-3}$ & - & - & $(1.3 \pm 0.3) \times 10^{-3}$ & $0.016 \pm 0.003$ \\
\hline Benzene, 4-ethyl-1,2-dimethyl- & $\mathrm{C}_{10} \mathrm{H}_{14}$ & 1639.48 & 1.619 & $(2.4 \pm 0.9) \times 10^{-3}$ & $(3.9 \pm 1.1) \times 10^{-3}$ & - & - & $(1.1 \pm 0.2) \times 10^{-3}$ & $0.013 \pm 0.003$ \\
\hline Benzene, 2-ethyl-1,3-dimethyl- & $\mathrm{C}_{10} \mathrm{H}_{14}$ & 1659.48 & 1.668 & - & $(2.4 \pm 0.6) \times 10^{-3}$ & - & - & $(1.1+0.2) \times 10$ & $(6.5 \pm 1.6) \times 10^{-3}$ \\
\hline 1,2-Dimethyl-3-ethylbenzene & $\mathrm{C}_{10} \mathrm{H}_{14}$ & 1694.46 & 1.698 & $(2.2 \pm 0.9) \times 10^{-3}$ & $(2.9 \pm 1.1) \times 10^{-3}$ & - & - & $(6.5 \pm 2.4) \times 10^{-4}$ & - \\
\hline $1,2,3,5$-tetramethylbenzene & $\mathrm{C}_{10} \mathrm{H}_{14}$ & 1749.45 & 1.703 & $(7.1 \pm 3.5) \times 10^{-3}$ & $(7.6 \pm 3.8) \times 10^{-3}$ & - & - & $(1.7 \pm 0.9) \times 10^{-3}$ & $0.022 \pm 0.011$ \\
\hline Benzene, 1,2,3,4-tetramethyl- & $\mathrm{C}_{10} \mathrm{H}_{14}$ & 1824.42 & 1.786 & - & - & - & - & - & $0.036 \pm 0.007$ \\
\hline $\mathrm{C}_{11} \mathrm{H}_{16}$ isomer & $\mathrm{C}_{11} \mathrm{H}_{16}$ & 1664.47 & 1.456 & $(4.4 \pm 2.3) \times 10^{-3}$ & $(5.5 \pm 2.8) \times 10^{-3}$ & - & - & - & $0.016 \pm 0.008$ \\
\hline $\mathrm{C}_{11} \mathrm{H}_{16}$ isomer & $\mathrm{C}_{11} \mathrm{H}_{16}$ & 1684.47 & 1.487 & - & $(3.9 \pm 2.7) \times 10^{-3}$ & - & - & - & - \\
\hline $\mathrm{C}_{11} \mathrm{H}_{16}$ isomer & $\mathrm{C}_{11} \mathrm{H}_{16}$ & 1754.44 & 1.544 & - & - & - & - & - & $0.012 \pm 0.008$ \\
\hline $\mathrm{C}_{11} \mathrm{H}_{16}$ isomer & $\mathrm{C}_{11} \mathrm{H}_{16}$ & 1769.44 & 1.54 & - & - & - & - & - & $0.015 \pm 0.008$ \\
\hline $\mathrm{C}_{11} \mathrm{H}_{16}$ isomer & $\mathrm{C}_{11} \mathrm{H}_{16}$ & 1774.44 & 1.531 & $(3.6 \pm 2.3) \times 10^{-3}$ & $(4.3 \pm 2.7) \times 10^{-3}$ & - & - & - & $0.012 \pm 0.008$ \\
\hline Benzene, pentyl- & $\mathrm{C}_{11} \mathrm{H}_{16}$ & 1799.43 & 1.531 & $0.011 \pm 0.003$ & $0.011 \pm 0.003$ & - & - & $(1.2 \pm 0.6) \times 10^{-3}$ & $0.026 \pm 0.008$ \\
\hline $\mathrm{C}_{11} \mathrm{H}_{16}$ isomer & $\mathrm{C}_{11} \mathrm{H}_{16}$ & 1829.42 & 1.566 & $(4.9 \pm 2.5) \times 10^{-3}$ & $(6.3 \pm 3.2) \times 10^{-3}$ & - & - & $(3.7 \pm 1.9) \times 10^{-4}$ & $\begin{array}{r}0.020 \pm 0.01 \\
0.020\end{array}$ \\
\hline Benzene, hexyl- & $\mathrm{C}_{12} \mathrm{H}_{18}$ & 2029.36 & 1.518 & $(2.7 \pm 1.4) \times 10^{-3}$ & $(3.6 \pm 1.8) \times 10^{-3}$ & - & - & $(6.0 \pm 3.7) \times 10^{-4}$ & $0.019 \pm 0.005$ \\
\hline Benzene, (1,3-dimethylbutyl)- & $\mathrm{C}_{12} \mathrm{H}_{18}$ & 2054.35 & 1.553 & - & $(2.9 \pm 1.7) \times 10^{-3}$ & - & - & - & $0.011 \pm 0.005$ \\
\hline Benzene, heptyl- & $\mathrm{C}_{13} \mathrm{H}_{20}$ & 2249.29 & 1.509 & - & - & - & - & - & $(9.3 \pm 5.0) \times 10^{-3}$ \\
\hline 1 DBE (of substituents) & & & & & & & & & \\
\hline Styrene & $\mathrm{C}_{8} \mathrm{H}_{8}$ & 1119.65 & 2.094 & $0.098 \pm 0.02$ & $0.14 \pm 0.03$ & $0.036 \pm 0.007$ & $(6.3 \pm 1.3) \times 10^{-3}$ & $0.028 \pm 0.006$ & $0.084 \pm 0.017$ \\
\hline Benzene, 2-propenyl- & $\mathrm{C}_{9} \mathrm{H}_{10}$ & 1259.6 & 1.826 & $(5.1 \pm 2.5) \times 10^{-3}$ & $(6.4 \pm 3.2) \times 10^{-3}$ & - & - & $(1.3 \pm 0.6) \times 10^{-3}$ & $0.012 \pm 0.006$ \\
\hline$\alpha$-Methylstyrene & $\mathrm{C}_{9} \mathrm{H}_{10}$ & 1364.57 & 1.914 & $0.013 \pm 0.003$ & $0.016 \pm 0.003$ & $(1.2 \pm 0.3) \times 10^{-3}$ & - & $(2.3 \pm 0.5) \times 10^{-3}$ & $(6.5 \pm 2.7) \times 10^{-3}$ \\
\hline cis-1-Propenylbenzene & $\mathrm{C}_{9} \mathrm{H}_{10}$ & 1384.56 & 1.892 & $(3.7 \pm 0.8) \times 10^{-3}$ & $(5.0 \pm 1.0) \times 10^{-3}$ & - & - & $(1.2 \pm 0.2) \times 10^{-3}$ & $(8.2 \pm 2.6) \times 10^{-3}$ \\
\hline Benzene, 1-ethenyl-3-methyl- & $\mathrm{C}_{9} \mathrm{H}_{10}$ & 1414.55 & 1.954 & $0.045 \pm 0.022$ & $0.063 \pm 0.031$ & $(6.0 \pm 3.0) \times 10^{-3}$ & $(1.9 \pm 1.0) \times 10^{-3}$ & $(9.9 \pm 5.0) \times 10^{-3}$ & $0.044 \pm 0.022$ \\
\hline 4-Methyl styrene & $\mathrm{C}_{9} \mathrm{H}_{10}$ & 1424.55 & 1.949 & $0.011 \pm 0.005$ & $0.011 \pm 0.006$ & $(1.6 \pm 0.8) \times 10^{-3}$ & - & $(2.4 \pm 1.2) \times 10^{-3}$ & - \\
\hline Benzene, 1-propenyl, trans & $\mathrm{C}_{9} \mathrm{H}_{10}$ & 1494.53 & 2.02 & $(7.5 \pm 1.5) \times 10^{-3}$ & $0.011 \pm 0.002$ & $(1.3 \pm 0.3) \times 10^{-3}$ & - & $(2.4 \pm 0.5) \times 10^{-3}$ & $0.020 \pm 0.004$ \\
\hline Indane & $\mathrm{C}_{9} \mathrm{H}_{10}$ & 1509.52 & 1.91 & $(6.0 \pm 3.0) \times 10^{-3}$ & $0.011 \pm 0.006$ & $(9.1 \pm 4.6) \times 10^{-4}$ & - & $(2.3 \pm 1.2) \times 10^{-3}$ & $0.026 \pm 0.013$ \\
\hline o-Isopropenyltoluene & $\mathrm{C}_{10} \mathrm{H}_{12}$ & 1439.55 & 1.628 & $(2.2 \pm 0.4) \times 10^{-3}$ & $(3.9 \pm 0.8) \times 10^{-3}$ & - & - & - & - \\
\hline $\mathrm{C}_{10} \mathrm{H}_{12}$ isomer & $\mathrm{C}_{10} \mathrm{H}_{12}$ & 1519.52 & 1.769 & $(2.8 \pm 1.4) \times 10^{-3}$ & $(4.2 \pm 2.1) \times 10^{-3}$ & - & - & $(8.9 \pm 4.5) \times 10^{-4}$ & $(7.7 \pm 3.9) \times 10^{-3}$ \\
\hline $\mathrm{C}_{10} \mathrm{H}_{12}$ isomer & $\mathrm{C}_{10} \mathrm{H}_{12}$ & 1554.51 & 1.791 & $(2.8 \pm 1.4) \times 10^{-3}$ & - & - & - & $(6.5 \pm 3.2) \times 10^{-4}$ & - \\
\hline $\mathrm{C}_{10} \mathrm{H}_{12}$ isomer & $\mathrm{C}_{10} \mathrm{H}_{12}$ & 1609.49 & 1.822 & $(2.3 \pm 1.1) \times 10^{-3}$ & - & - & - & $(6.5 \pm 3.2) \times 10^{-4}$ & $(7.3 \pm 3.7) \times 10^{-3}$ \\
\hline $\mathrm{C}_{10} \mathrm{H}_{12}$ isomer & $\mathrm{C}_{10} \mathrm{H}_{12}$ & 1614.49 & 1.782 & - & $(4.0 \pm 2.0) \times 10^{-3}$ & - & - & - & - \\
\hline $\mathrm{C}_{10} \mathrm{H}_{12}$ isomer & $\mathrm{C}_{10} \mathrm{H}_{12}$ & 1624.49 & 1.822 & $(6.5 \pm 3.2) \times 10^{-3}$ & $0.012 \pm 0.006$ & - & - & $(1.2 \pm 0.6) \times 10^{-3}$ & - \\
\hline $\mathrm{C}_{10} \mathrm{H}_{12}$ isomer & $\mathrm{C}_{10} \mathrm{H}_{12}$ & 1634.48 & 1.857 & $(4.5 \pm 2.2) \times 10^{-3}$ & $(7.9 \pm 3.9) \times 10^{-3}$ & - & - & (1.2 & - \\
\hline $\mathrm{C}_{10} \mathrm{H}_{12}$ isomer & $\mathrm{C}_{10} \mathrm{H}_{12}$ & 1639.48 & 1.764 & 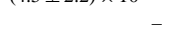 & - & - & - & $(1.7 \pm 0.8) \times 10^{-3}$ & $0.011 \pm 0.005$ \\
\hline $\mathrm{C}_{10} \mathrm{H}_{12}$ isomer & $\mathrm{C}_{10} \mathrm{H}_{12}$ & 1649.48 & 1.826 & $0.024 \pm 0.012$ & $0.024 \pm 0.012$ & - & - & $(1.5 \pm 0.8) \times 10^{-3}$ & $0.019 \pm 0.01$ \\
\hline $\mathrm{C}_{10} \mathrm{H}_{12}$ isomer & $\mathrm{C}_{10} \mathrm{H}_{12}$ & 1659.48 & 1.866 & $(2.4 \pm 1.2) \times 10^{-3}$ & $(3.3 \pm 1.7) \times 10^{-3}$ & - & - & $(7.3 \pm 3.7) \times 10^{-4}$ & 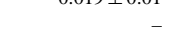 \\
\hline $\mathrm{C}_{10} \mathrm{H}_{12}$ isomer & $\mathrm{C}_{10} \mathrm{H}_{12}$ & 1679.47 & 1.874 & - & - & - & - & $(7.4 \pm 3.7) \times 10^{-4}$ & - \\
\hline $\mathrm{C}_{10} \mathrm{H}_{12}$ isomer & $\mathrm{C}_{10} \mathrm{H}_{12}$ & 1689.47 & 1.866 & - & - & - & - & $(6.5 \pm 3.2) \times 10^{-4}$ & - \\
\hline $\mathrm{C}_{10} \mathrm{H}_{12}$ isomer & $\mathrm{C}_{10} \mathrm{H}_{12}$ & 1734.45 & 1.901 & $(3.0 \pm 1.5) \times 10^{-3}$ & $(3.4 \pm 1.7) \times 10^{-3}$ & - & - & - & - \\
\hline
\end{tabular}


Table A1. Continued.

\begin{tabular}{|c|c|c|c|c|c|c|c|c|c|}
\hline $\mathrm{C}_{10} \mathrm{H}_{12}$ isomer & $\mathrm{C}_{10} \mathrm{H}_{12}$ & 1759.44 & 1.923 & $(3.3 \pm 1.6) \times 10^{-3}$ & $(4.6 \pm 2.3) \times 10^{-3}$ & - & - & $(1.4 \pm 0.7) \times 10^{-3}$ & $(7.9 \pm 3.9) \times 10^{-3}$ \\
\hline $\mathrm{C}_{10} \mathrm{H}_{12}$ isomer & $\mathrm{C}_{10} \mathrm{H}_{12}$ & 1779.44 & 1.835 & $(2.1 \pm 1.0) \times 10^{-3}$ & $(3.6 \pm 1.8) \times 10^{-3}$ & - & - & $(8.7 \pm 4.3) \times 10^{-4}$ & $0.011 \pm 0.005$ \\
\hline $\mathrm{C}_{10} \mathrm{H}_{12}$ isomer & $\mathrm{C}_{10} \mathrm{H}_{12}$ & 1804.43 & 1.896 & - & $(3.9 \pm 2.0) \times 10^{-3}$ & - & - & $(8.8 \pm 4.4) \times 10^{-4}$ & $0.014 \pm 0.007$ \\
\hline $\mathrm{C}_{10} \mathrm{H}_{12}$ isomer & $\mathrm{C}_{10} \mathrm{H}_{12}$ & 1829.42 & 1.98 & - & $(3.0 \pm 1.5) \times 10^{-3}$ & - & - & - & $(8.5 \pm 4.3) \times 10^{-3}$ \\
\hline $\mathrm{C}_{11} \mathrm{H}_{14}$ isomer & $\mathrm{C}_{11} \mathrm{H}_{14}$ & 1769.44 & 1.729 & $(4.3 \pm 2.1) \times 10^{-3}$ & $(4.1 \pm 2.1) \times 10^{-3}$ & - & - & - & - \\
\hline $\mathrm{C}_{11} \mathrm{H}_{14}$ isomer & $\mathrm{C}_{11} \mathrm{H}_{14}$ & 1909.4 & 1.769 & - & - & - & - & - & $0.011 \pm 0.008$ \\
\hline $\mathrm{C}_{14} \mathrm{H}_{20}$ isomer & $\mathrm{C}_{14} \mathrm{H}_{20}$ & 2584.18 & 1.91 & - & - & - & - & - & $0.018 \pm 0.009$ \\
\hline \multicolumn{10}{|l|}{2 DBE (of substituents) } \\
\hline Phenylacetylene & $\mathrm{C}_{8} \mathrm{H}_{6}$ & 1064.67 & 3.089 & $0.027 \pm 0.005$ & $0.032 \pm 0.006$ & $0.026 \pm 0.005$ & $(2.9 \pm 0.7) \times 10^{-3}$ & $(5.5 \pm 1.1) \times 10^{-3}$ & - \\
\hline Benzene, 1-ethynyl-2-methyl- & $\mathrm{C}_{9} \mathrm{H}_{8}$ & 1369.57 & 2.715 & $(4.1 \pm 2.0) \times 10^{-3}$ & $(5.0 \pm 2.5) \times 10^{-3}$ & $(1.4 \pm 0.7) \times 10^{-3}$ & - & $(4.0 \pm 2.0) \times 10^{-4}$ & - \\
\hline Indene & $\mathrm{C}_{9} \mathrm{H}_{8}$ & 1544.51 & 2.429 & $0.052 \pm 0.026$ & $0.068 \pm 0.034$ & $0.030 \pm 0.015$ & $(2.8 \pm 1.4) \times 10^{-3}$ & $0.014 \pm 0.007$ & $0.028 \pm 0.014$ \\
\hline $\mathrm{C}_{10} \mathrm{H}_{10}$ isomer & $\mathrm{C}_{10} \mathrm{H}_{10}$ & 1634.48 & 2.103 & $(2.2 \pm 1.1) \times 10^{-3}$ & $(2.8 \pm 1.4) \times 10^{-3}$ & - & - & $(6.3 \pm 3.1) \times 10^{-4}$ & - \\
\hline $\mathrm{C}_{10} \mathrm{H}_{10}$ isomer & $\mathrm{C}_{10} \mathrm{H}_{10}$ & 1714.46 & 2.288 & $(2.8 \pm 1.4) \times 10^{-3}$ & $(3.4 \pm 1.7) \times 10^{-3}$ & - & - & $(5.0 \pm 2.5) \times 10^{-4}$ & - \\
\hline $\mathrm{C}_{10} \mathrm{H}_{10}$ isomer & $\mathrm{C}_{10} \mathrm{H}_{10}$ & 1814.43 & 2.248 & $0.013 \pm 0.006$ & $0.020 \pm 0.01$ & $(3.4 \pm 1.7) \times 10^{-3}$ & $(1.2 \pm 0.6) \times 10^{-3}$ & $(5.9 \pm 3.0) \times 10^{-3}$ & $0.020 \pm 0.01$ \\
\hline $\mathrm{C}_{10} \mathrm{H}_{10}$ isomer & $\mathrm{C}_{10} \mathrm{H}_{10}$ & 1829.42 & 2.319 & $(8.7 \pm 4.3) \times 10^{-3}$ & $0.016 \pm 0.008$ & $(2.0 \pm 1.0) \times 10^{-3}$ & - & $(4.9 \pm 2.4) \times 10^{-3}$ & $0.020 \pm 0.01$ \\
\hline $\mathrm{C}_{10} \mathrm{H}_{10}$ isomer & $\mathrm{C}_{10} \mathrm{H}_{10}$ & 1839.42 & 2.341 & $(4.0 \pm 2.0) \times 10^{-3}$ & $(5.0 \pm 2.5) \times 10^{-3}$ & $(6.2 \pm 3.1) \times 10^{-4}$ & - & $(1.2 \pm 0.6) \times 10^{-3}$ & - \\
\hline $\mathrm{C}_{11} \mathrm{H}_{12}$ isomer & $\mathrm{C}_{11} \mathrm{H}_{12}$ & 1869.41 & 1.993 & - & - & - & - & $(4.5 \pm 2.2) \times 10^{-4}$ & - \\
\hline $\mathrm{C}_{11} \mathrm{H}_{12}$ isomer & $\mathrm{C}_{11} \mathrm{H}_{12}$ & 2024.36 & 2.178 & - & - & - & - & $(5.8 \pm 2.9) \times 10^{-4}$ & - \\
\hline $\mathrm{C}_{11} \mathrm{H}_{12}$ isomer & $\mathrm{C}_{11} \mathrm{H}_{12}$ & 2064.35 & 2.13 & $(1.7 \pm 0.9) \times 10^{-3}$ & $(2.5 \pm 1.3) \times 10^{-3}$ & - & - & $(9.2 \pm 4.6) \times 10^{-4}$ & $(6.7 \pm 3.3) \times 10^{-3}$ \\
\hline $\mathrm{C}_{11} \mathrm{H}_{12}$ isomer & $\mathrm{C}_{11} \mathrm{H}_{12}$ & 2079.34 & 2.196 & $(2.6 \pm 1.3) \times 10^{-3}$ & $(4.5 \pm 2.2) \times 10^{-3}$ & - & - & $(1.6 \pm 0.8) \times 10^{-3}$ & $0.010 \pm 0.005$ \\
\hline $\mathrm{C}_{11} \mathrm{H}_{12}$ isomer & $\mathrm{C}_{11} \mathrm{H}_{12}$ & 2089.34 & 2.248 & $(2.9 \pm 1.4) \times 10^{-3}$ & $(5.0 \pm 2.5) \times 10^{-3}$ & - & - & $(1.7 \pm 0.9) \times 10^{-3}$ & - \\
\hline $\mathrm{C}_{11} \mathrm{H}_{12}$ Isomer & $\mathrm{C}_{11} \mathrm{H}_{12}$ & 2094.34 & 2.226 & - & - & - & - & - & $0.010 \pm 0.005$ \\
\hline \multicolumn{10}{|l|}{ PAHs (and related) } \\
\hline Naphthalene & $\mathrm{C}_{10} \mathrm{H}_{8}$ & 1909.4 & 2.952 & $0.083 \pm 0.017$ & $0.089 \pm 0.018$ & $0.070 \pm 0.014$ & $(4.8 \pm 1.0) \times 10^{-3}$ & $0.026 \pm 0.005$ & $0.046 \pm 0.009$ \\
\hline Naphthalene, 2-methyl- & $\mathrm{C}_{11} \mathrm{H}_{10}$ & 2164.31 & 2.741 & $0.014 \pm 0.003$ & $0.016 \pm 0.003$ & $(5.5 \pm 1.1) \times 10^{-3}$ & $(2.4 \pm 0.7) \times 10^{-3}$ & $(6.9 \pm 1.4) \times 10^{-3}$ & $0.035 \pm 0.007$ \\
\hline Naphthalene, 1-methyl- & $\mathrm{C}_{11} \mathrm{H}_{10}$ & 2199.3 & 2.847 & $0.013 \pm 0.003$ & $0.016 \pm 0.003$ & $(5.0 \pm 1.0) \times 10^{-3}$ & - & $(5.5 \pm 1.1) \times 10^{-3}$ & $0.034 \pm 0.007$ \\
\hline Biphenyl & $\mathrm{C}_{12} \mathrm{H}_{10}$ & 2314.27 & 2.952 & $(6.4 \pm 2.3) \times 10^{-3}$ & $(5.9 \pm 2.8) \times 10^{-3}$ & $(3.3 \pm 0.8) \times 10^{-3}$ & - & $(2.3 \pm 0.6) \times 10^{-3}$ & $0.021 \pm 0.008$ \\
\hline Naphthalene, 1-ethyl- & $\mathrm{C}_{12} \mathrm{H}_{12}$ & 2364.25 & 2.596 & $(5.6 \pm 5.5) \times 10^{-3}$ & - & - & - & $(1.5 \pm 1.4) \times 10^{-3}$ & - \\
\hline Naphthalene, 1,6-dimethyl- & $\mathrm{C}_{12} \mathrm{H}_{12}$ & 2429.23 & 2.662 & - & - & - & - & $(1.5 \pm 1.4) \times 10^{-3}$ & - \\
\hline Naphthalene, 1,3-dimethyl- & $\mathrm{C}_{12} \mathrm{H}_{12}$ & 2439.23 & 2.666 & $(5.6 \pm 5.5) \times 10^{-3}$ & $(6.5 \pm 6.6) \times 10^{-3}$ & - & - & $(2.0 \pm 1.4) \times 10^{-3}$ & $0.047 \pm 0.023$ \\
\hline Acenaphthylene & $\mathrm{C}_{12} \mathrm{H}_{8}$ & 2494.21 & 3.744 & $0.011 \pm 0.002$ & $0.012 \pm 0.002$ & $0.017 \pm 0.003$ & $(3.2 \pm 0.9) \times 10^{-3}$ & $(3.6 \pm 0.7) \times 10^{-3}$ & - \\
\hline \multicolumn{10}{|l|}{ Other } \\
\hline 4-Phenylbut-3-ene-1-yne & $\mathrm{C}_{10} \mathrm{H}_{8}$ & 1844.42 & 2.886 & $(3.4 \pm 1.7) \times 10^{-3}$ & $(5.3 \pm 2.7) \times 10^{-3}$ & $(1.1 \pm 0.6) \times 10^{-3}$ & - & $(1.3 \pm 0.6) \times 10^{-3}$ & - \\
\hline \multicolumn{10}{|l|}{ Oxygenated aromatic compounds } \\
\hline \multicolumn{10}{|l|}{ Alcohols } \\
\hline Phenol & $\mathrm{C}_{6} \mathrm{H}_{6} \mathrm{O}$ & 1334.58 & 3.538 & $0.13 \pm 0.03$ & $0.48 \pm 0.1$ & $0.15 \pm 0.03$ & $0.057 \pm 0.011$ & $0.26 \pm 0.05$ & $0.47 \pm 0.09$ \\
\hline Phenol, 2-methyl & $\mathrm{C}_{7} \mathrm{H}_{8} \mathrm{O}$ & 1524.52 & 3.56 & $0.021 \pm 0.006$ & $0.050 \pm 0.01$ & $0.015 \pm 0.003$ & $0.011 \pm 0.003$ & $0.043 \pm 0.009$ & $0.095 \pm 0.02$ \\
\hline Phenol, 3+4-methyl & $\mathrm{C}_{7} \mathrm{H}_{8} \mathrm{O}$ & 1579.5 & 0.959 & $0.019 \pm 0.004$ & $0.043 \pm 0.009$ & $0.010 \pm 0.002$ & $0.012 \pm 0.002$ & $0.027 \pm 0.005$ & - \\
\hline o-Guaiacol & $\mathrm{C}_{7} \mathrm{H}_{8} \mathrm{O}_{2}$ & 1644.48 & 1.065 & $0.013 \pm 0.003$ & $0.055 \pm 0.011$ & - & $0.020 \pm 0.004$ & $0.011 \pm 0.002$ & $0.079 \pm 0.016$ \\
\hline Phenol, 2,6-dimethyl- & $\mathrm{C}_{8} \mathrm{H}_{10} \mathrm{O}$ & 1679.47 & 1.584 & - & - & - & - & $(3.8 \pm 1.9) \times 10^{-3}$ & - \\
\hline Phenol, 2,5-dimethyl- & $\mathrm{C}_{8} \mathrm{H}_{10} \mathrm{O}$ & 1764.44 & 4.704 & - & $0.011 \pm 0.002$ & - & - & $(7.9 \pm 2.8) \times 10^{-3}$ & - \\
\hline \multicolumn{10}{|l|}{ Aldehydes } \\
\hline Benzaldehyde & $\mathrm{C}_{7} \mathrm{H}_{6} \mathrm{O}$ & 1309.59 & 3.802 & $0.060 \pm 0.012$ & $0.071 \pm 0.014$ & $0.034 \pm 0.007$ & $(4.4 \pm 3.4) \times 10^{-3}$ & $0.020 \pm 0.004$ & $0.030 \pm 0.016$ \\
\hline Salicyladehyde & $\mathrm{C}_{7} \mathrm{H}_{6} \mathrm{O}_{2}$ & 1529.52 & 4.343 & - & $0.015 \pm 0.003$ & $(7.3 \pm 1.5) \times 10^{-3}$ & - & $(6.4 \pm 1.3) \times 10^{-3}$ & - \\
\hline Benzeneacetaldehyde & $\mathrm{C}_{8} \mathrm{H}_{8} \mathrm{O}$ & 1519.52 & 3.85 & $(1.3 \pm 0.6) \times 10^{-3}$ & $(3.2 \pm 5.5) \times 10^{-3}$ & - & - & $(7.9 \pm 11.8) \times 10^{-4}$ & - \\
\hline Benzaldehyde, 2+3-methyl- & $\mathrm{C}_{8} \mathrm{H}_{8} \mathrm{O}$ & 1604.49 & 3.247 & $0.020 \pm 0.004$ & $0.025 \pm 0.005$ & $(4.8 \pm 1.0) \times 10^{-3}$ & - & $(7.3 \pm 1.5) \times 10^{-3}$ & - \\
\hline \multicolumn{10}{|l|}{ Ketones } \\
\hline Acetophenone & $\mathrm{C}_{8} \mathrm{H}_{8} \mathrm{O}$ & 1594.5 & 3.533 & $(4.0 \pm 0.8) \times 10^{-3}$ & $(6.7 \pm 1.3) \times 10^{-3}$ & $(1.4 \pm 0.3) \times 10^{-3}$ & $(5.5 \pm 5.0) \times 10^{-4}$ & $(4.8 \pm 1.0) \times 10^{-3}$ & $0.011 \pm 0.002$ \\
\hline Acetophenone, $3^{\prime}$ - meth $y l-$ & $\mathrm{C}_{9} \mathrm{H}_{10} \mathrm{O}$ & 1864.41 & 3.115 & - & - & - & - & $(1.7 \pm 0.3) \times 10^{-3}$ & - \\
\hline 1,2-Naphthalenedione & $\mathrm{C}_{10} \mathrm{H}_{6} \mathrm{O}_{2}$ & 1904.4 & 4.299 & - & - & $(6.7 \pm 3.3) \times 10^{-4}$ & - & - & - \\
\hline 3,3-Dimethyl-1-indanone & $\mathrm{C}_{11} \mathrm{H}_{12} \mathrm{O}$ & 2179.31 & 2.262 & - & - & - & - & $(1.7 \pm 0.8) \times 10^{-3}$ & - \\
\hline \multicolumn{10}{|l|}{ Furans } \\
\hline Benzofuran & $\mathrm{C}_{8} \mathrm{H}_{6} \mathrm{O}$ & 1419.55 & 2.979 & $0.036 \pm 0.007$ & $0.045 \pm 0.009$ & $0.023 \pm 0.005$ & $(5.4 \pm 1.1) \times 10^{-3}$ & $0.019 \pm 0.004$ & $0.048 \pm 0.01$ \\
\hline Benzofuran, 2,3-dihydro- & $\mathrm{C}_{8} \mathrm{H}_{8} \mathrm{O}$ & 1624.49 & 2.913 & - & - & - & - & $(1.1 \pm 0.6) \times 10^{-3}$ & - \\
\hline Methyl-benzofuran isomer & $\mathrm{C}_{9} \mathrm{H}_{8} \mathrm{O}$ & 1684.47 & 2.627 & $(4.1 \pm 2.1) \times 10^{-3}$ & $(6.0 \pm 3.0) \times 10^{-3}$ & $(1.7 \pm 0.9) \times 10^{-3}$ & - & $(3.0 \pm 1.5) \times 10^{-3}$ & $0.011 \pm 0.006$ \\
\hline Methyl-benzofuran isomer & $\mathrm{C}_{9} \mathrm{H}_{8} \mathrm{O}$ & 1704.46 & 2.675 & $(8.1 \pm 4.0) \times 10^{-3}$ & $0.012 \pm 0.006$ & $(2.8 \pm 1.4) \times 10^{-3}$ & $(2.2 \pm 1.1) \times 10^{-3}$ & $(6.2 \pm 3.1) \times 10^{-3}$ & $0.023 \pm 0.012$ \\
\hline Methyl-benzofuran isomer & $\mathrm{C}_{9} \mathrm{H}_{8} \mathrm{O}$ & 1714.46 & 2.565 & $(6.8 \pm 3.4) \times 10^{-3}$ & $0.013 \pm 0.007$ & $(2.2 \pm 1.1) \times 10^{-3}$ & $(2.1 \pm 1.0) \times 10^{-3}$ & $(5.3 \pm 2.6) \times 10^{-3}$ & $0.027 \pm 0.014$ \\
\hline Ethyl-benzofuran isomer & $\mathrm{C}_{10} \mathrm{H}_{10} \mathrm{O}$ & 1924.39 & 2.504 & - & - & - & 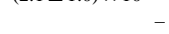 & $(1.4 \pm 0.7) \times 10^{-3}$ & - \\
\hline Ethyl-benzofuran isomer & $\mathrm{C}_{10} \mathrm{H}_{10} \mathrm{O}$ & 1939.39 & 2.341 & - & - & - & - & $(8.3 \pm 4.2) \times 10^{-4}$ & - \\
\hline Benzofuran, -dimethyl- (isomer) & $\mathrm{C}_{10} \mathrm{H}_{10} \mathrm{O}$ & 1944.38 & 2.336 & - & $(4.0 \pm 2.0) \times 10^{-3}$ & - & - & $(1.7 \pm 0.9) \times 10^{-3}$ & $0.013 \pm 0.007$ \\
\hline Benzofuran, dimethyl- (isomer) & $\mathrm{C}_{10} \mathrm{H}_{10} \mathrm{O}$ & 1974.37 & 2.385 & $(3.2 \pm 1.6) \times 10^{-3}$ & $(6.2 \pm 3.1) \times 10^{-3}$ & - & - & $(3.0 \pm 1.5) \times 10^{-3}$ & $0.016 \pm 0.008$ \\
\hline Ethyl-benzofuran isomer & $\mathrm{C}_{10} \mathrm{H}_{10} \mathrm{O}$ & 1989.37 & 2.394 & - & - & - & - & $(1.0 \pm 0.5) \times 10^{-3}$ & - \\
\hline Benzofuran, 2-ethenyl- & $\mathrm{C}_{10} \mathrm{H}_{8} \mathrm{O}$ & 2004.36 & 3.164 & - & - & - & - & $(10.0 \pm 5.0) \times 10^{-4}$ & - \\
\hline
\end{tabular}


Table A1. Continued.

\begin{tabular}{|c|c|c|c|c|c|c|c|c|c|}
\hline Ethers and esters & & & & & & & & & \\
\hline Anisole & $\mathrm{C}_{7} \mathrm{H}_{8} \mathrm{O}$ & 1189.63 & 2.468 & $(4.2 \pm 0.9) \times 10^{-3}$ & $(8.2 \pm 1.6) \times 10^{-3}$ & $(1.6 \pm 0.3) \times 10^{-3}$ & $(8.7 \pm 4.9) \times 10^{-4}$ & $(1.5 \pm 0.3) \times 10^{-3}$ & - \\
\hline 4-Methyl anisole & $\mathrm{C}_{8} \mathrm{H}_{10} \mathrm{O}$ & 1474.53 & 2.244 & $(4.4 \pm 2.2) \times 10^{-3}$ & $0.011 \pm 0.005$ & 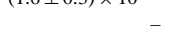 & $(1.9 \pm 0.9) \times 10^{-3}$ & $(1.7 \pm 0.8) \times 10^{-3}$ & $0.010 \pm 0.005$ \\
\hline Acetic acid, phenyl ester & $\mathrm{C}_{8} \mathrm{H}_{8} \mathrm{O}_{2}$ & 1564.51 & 3.252 & (1.7. & 0.010 & - & (1.) & $(7.9 \pm 3.9) \times 10^{-4}$ & $0.010+0.000$ \\
\hline 2,3-Dimethylanisole & $\mathrm{C}_{9} \mathrm{H}_{12} \mathrm{O}$ & 1694.46 & 2.011 & - & - & - & - & - & $(6.0 \pm 3.2) \times 10^{-3}$ \\
\hline 4-ethyl anisole & $\mathrm{C}_{9} \mathrm{H}_{12} \mathrm{O}$ & 1704.46 & 2.13 & - & - & - & - & $(5.3 \pm 2.7) \times 10^{-4}$ & $(0.0+0.5) \times 10$ \\
\hline Benzoic acid, methyl ester & $\mathrm{C}_{8} \mathrm{H}_{8} \mathrm{O}_{2}$ & 1664.47 & 2.904 & - & $0.016 \pm 0.008$ & - & - & - & $(5.1 \pm 2.5) \times 10^{-3}$ \\
\hline Benzene, 1-ethenyl-4-methoxy- & $\mathrm{C}_{9} \mathrm{H}_{10} \mathrm{O}$ & 1804.43 & 2.706 & - & $0.010+0.000$ & - & - & $(5.5 \pm 2.8) \times 10^{-4}$ & $(J .1+2.5) \times 10$ \\
\hline Estragole & $\mathrm{C}_{10} \mathrm{H}_{12} \mathrm{O}$ & 1899.4 & 2.341 & - & $0.013 \pm 0.003$ & - & - & - & - \\
\hline \multicolumn{10}{|l|}{ Other } \\
\hline 1,3-Benzodioxole & $\mathrm{C}_{7} \mathrm{H}_{6} \mathrm{O}_{2}$ & 1419.55 & 3.238 & $(3.7 \pm 1.8) \times 10^{-3}$ & - & $(2.1 \pm 1.0) \times 10^{-3}$ & - & $(1.3 \pm 0.6) \times 10^{-3}$ & - \\
\hline \multicolumn{10}{|l|}{ Aliphatic hydrocarbons } \\
\hline \multicolumn{10}{|l|}{$0 \mathrm{DBE}$} \\
\hline Butane, 2-methyl- & $\mathrm{C}_{5} \mathrm{H}_{12}$ & 159.955 & 0.898 & $(4.9 \pm 1.0) \times 10^{-3}$ & - & - & - & $(1.2 \pm 0.4) \times 10^{-3}$ & $0.036 \pm 0.014$ \\
\hline Pentane & $\mathrm{C}_{5} \mathrm{H}_{12}$ & 174.95 & $\begin{array}{l}0.090 \\
0.906\end{array}$ & $0.032 \pm 0.012$ & $0.064 \pm 0.015$ & - & - & $(8.6 \pm 3.4) \times 10^{-3}$ & $0.33 \pm 0.07$ \\
\hline Pentane, 2-methyl- & $\mathrm{C}_{6} \mathrm{H}_{14}$ & 249.926 & 0.937 & $(2.7 \pm 1.6) \times 10^{-3}$ & $(7.5 \pm 2.5) \times 10^{-3}$ & - & - & $(1.2 \pm 0.5) \times 10^{-3}$ & $0.049 \pm 0.01$ \\
\hline Pentane, 3-methyl- & $\mathrm{C}_{6} \mathrm{H}_{14}$ & 269.92 & 0.95 & $(2.6+1.0)$ त 10 & $(4.5 \pm 1.9) \times 10^{-3}$ & - & - & - & $(8.1 \pm 5.1) \times 10^{-3}$ \\
\hline Hexane & $\mathrm{C}_{6} \mathrm{H}_{14}$ & 299.91 & 0.959 & $0.020 \pm 0.004$ & $0.048 \pm 0.01$ & - & - & $(3.7 \pm 1.1) \times 10^{-3}$ & $0.20 \pm 0.04$ \\
\hline Pentane, 2,4-dimethyl- & $\mathrm{C}_{7} \mathrm{H}_{16}$ & 359.891 & 0.959 & $\begin{array}{r}0.020 \pm 0.004 \\
-\end{array}$ & $(4.4 \pm 2.7) \times 10^{-4}$ & - & - & $(3.1+1.1) \times 10$ & $\begin{array}{r}0.2010 .04 \\
-\end{array}$ \\
\hline Hexane, 2-methyl- & $\mathrm{C}_{7} \mathrm{H}_{16}$ & 449.862 & 0.972 & $(2.8 \pm 0.6) \times 10^{-4}$ & $(7.1 \pm 2.8) \times 10^{-4}$ & - & $(1.5 \pm 0.3) \times 10^{-4}$ & $(0.8 \pm 0.2) \times 10^{-4}$ & $(7.8 \pm 1.6) \times 10^{-3}$ \\
\hline Pentane, 2,3-dimethyl- & $\mathrm{C}_{7} \mathrm{H}_{16}$ & 454.861 & 0.986 & $(8.6 \pm 2.3) \times 10^{-4}$ & $(1.7 \pm 0.9) \times 10^{-3}$ & - & (1.0 & $(0.0+0.2) \times 10$ & $(7.5 \pm 2.2) \times 10^{-3}$ \\
\hline Hexane, 3-methyl- & $\mathrm{C}_{7} \mathrm{H}_{16}$ & 469.856 & 0.981 & - & - & - & - & - & $0.010 \pm 0.003$ \\
\hline Heptane & $\mathrm{C}_{7} \mathrm{H}_{16}$ & 534.835 & 0.986 & $0.016 \pm 0.003$ & $0.032 \pm 0.006$ & - & $(1.4 \pm 0.3) \times 10^{-3}$ & $(2.8 \pm 0.6) \times 10^{-3}$ & $0.19 \pm 0.04$ \\
\hline Pentane, 2,2,4-trimethyl- & $\mathrm{C}_{8} \mathrm{H}_{18}$ & 509.843 & 0.968 & $(4.7 \pm 2.3) \times 10^{-3}$ & - & $(1.1 \pm 0.5) \times 10^{-3}$ & $(4.2 \pm 2.1) \times 10^{-3}$ & - & - \\
\hline Hexane, 2,5-dimethyl- & $\mathrm{C}_{8} \mathrm{H}_{18}$ & 624.806 & 0.977 & - & - & (12. & $(2.7 \pm 1.9) \times 10^{-4}$ & - & - \\
\hline Hexane, 2,3-dimethyl- & $\mathrm{C}_{8} \mathrm{H}_{18}$ & 709.779 & 0.994 & - & - & - & - & $(1.3 \pm 0.3) \times 10^{-4}$ & - \\
\hline Pentane, 2,3,3-trimethyl & $\mathrm{C}_{8} \mathrm{H}_{18}$ & 714.778 & 0.999 & $(1.6 \pm 12.4) \times 10^{-4}$ & - & - & - & - & $(5.2 \pm 2.6) \times 10^{-3}$ \\
\hline Heptane, 2-methyl- & $\mathrm{C}_{8} \mathrm{H}_{18}$ & 724.774 & 0.986 & - & - & - & - & - & $0.034 \pm 0.009$ \\
\hline Heptane, 3-methyl- & $\mathrm{C}_{8} \mathrm{H}_{18}$ & 744.768 & 0.99 & - & - & - & - & - & $(1.7 \pm 3.8) \times 10^{-3}$ \\
\hline Octane & $\mathrm{C}_{8} \mathrm{H}_{18}$ & 824.742 & 0.994 & $(9.5 \pm 2.3) \times 10^{-3}$ & $0.027 \pm 0.015$ & - & - & $(1.5 \pm 0.8) \times 10^{-3}$ & $0.18 \pm 0.04$ \\
\hline Heptane, 2,6-dimethyl- & $\mathrm{C}_{9} \mathrm{H}_{20}$ & 909.715 & 0.981 & - & $(1.6 \pm 0.8) \times 10^{-3}$ & - & - & - & $0.013 \pm 0.007$ \\
\hline Heptane, 2,3-dimethyl- & $\mathrm{C}_{9} \mathrm{H}_{20}$ & 989.69 & 0.999 & - & $(1.0+0.0) \times 10$ & - & - & - & $(6.3 \pm 1.6) \times 10^{-3}$ \\
\hline Octane, 2-methyl- & $\mathrm{C}_{9} \mathrm{H}_{20}$ & 1014.68 & 0.99 & - & - & - & - & - & $(5.9 \pm 3.9) \times 10^{-3}$ \\
\hline Octane, 3-methyl- & $\mathrm{C}_{9} \mathrm{H}_{20}$ & 1034.68 & 0.994 & - & - & - & - & - & $(5.7 \pm 3.4) \times 10^{-3}$ \\
\hline Nonane & $\mathrm{C}_{9} \mathrm{H}_{20}$ & $\begin{array}{l}1109.00 \\
1109.65\end{array}$ & $\begin{array}{l}0.994 \\
1.003\end{array}$ & $(6.2 \pm 1.9) \times 10^{-3}$ & $0.019 \pm 0.004$ & - & - & $(1.5 \pm 0.7) \times 10^{-3}$ & $0.15 \pm 0.03$ \\
\hline $\mathrm{C}_{10} \mathrm{H}_{22}$ isomer & $\mathrm{C}_{10} \mathrm{H}_{22}$ & 1209.62 & 0.994 & - & $(1.7 \pm 1.0) \times 10^{-3}$ & - & - & $(3.5 \pm 2.1) \times 10^{-4}$ & $0.021 \pm 0.01$ \\
\hline $\mathrm{C}_{10} \mathrm{H}_{22}$ isomer & $\mathrm{C}_{10} \mathrm{H}_{22}$ & 1229.61 & $\begin{array}{l}0.774 \\
1.008\end{array}$ & - & $(3.6 \pm 1.8) \times 10^{-3}$ & - & - & - & $0.017 \pm 0.008$ \\
\hline $\mathrm{C}_{10} \mathrm{H}_{22}$ isomer & $\mathrm{C}_{10} \mathrm{H}_{22}$ & 1234.61 & $\begin{array}{l}1.000 \\
1.003\end{array}$ & $(1.9 \pm 1.0) \times 10^{-3}$ & - & - & - & $(3.5 \pm 2.1) \times 10^{-4}$ & $\begin{array}{r}0.017+0.000 \\
-\end{array}$ \\
\hline Nonane, 2-methyl- & $\mathrm{C}_{10} \mathrm{H}_{22}$ & 1289.59 & 0.99 & - & $(1.1 \pm 0.2) \times 10^{-3}$ & - & - & - & $0.012 \pm 0.002$ \\
\hline Decane & $\mathrm{C}_{10} \mathrm{H}_{22}$ & 1384.56 & 1.012 & $(5.4 \pm 1.1) \times 10^{-3}$ & $0.014 \pm 0.003$ & - & - & $(1.3 \pm 0.3) \times 10^{-3}$ & $0.14 \pm 0.03$ \\
\hline $\mathrm{C}_{10} \mathrm{H}_{22}$ isomer & $\mathrm{C}_{10} \mathrm{H}_{22}$ & 1449.54 & 0.994 & 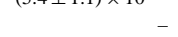 & $(2.2 \pm 1.1) \times 10^{-3}$ & - & - & $(3.5 \pm 2.1) \times 10^{-4}$ & $\begin{array}{r}0.14+0.00 \\
-\end{array}$ \\
\hline $\mathrm{C}_{11} \mathrm{H}_{24}$ isomer & $\mathrm{C}_{11} \mathrm{H}_{24}$ & 1449.54 & 0.999 & - & $(2.2+1.1) \times 10$ & - & - & - & $0.031 \pm 0.016$ \\
\hline $\mathrm{C}_{11} \mathrm{H}_{24}$ isomer & $\mathrm{C}_{11} \mathrm{H}_{24}$ & 1534.52 & 1.008 & - & - & - & - & - & $0.014 \pm 0.008$ \\
\hline $\mathrm{C}_{11} \mathrm{H}_{24}$ isomer & $\mathrm{C}_{11} \mathrm{H}_{24}$ & 1549.51 & 1.008 & - & - & - & - & - & $0.017 \pm 0.008$ \\
\hline Undecane & $\mathrm{C}_{11} \mathrm{H}_{24}$ & 1634.48 & 1.025 & $(4.6 \pm 3.1) \times 10^{-3}$ & $0.025 \pm 0.005$ & - & - & $(1.0 \pm 0.8) \times 10^{-3}$ & $0.11 \pm 0.02$ \\
\hline $\mathrm{C}_{12} \mathrm{H}_{26}$ isomer & $\mathrm{C}_{12} \mathrm{H}_{26}$ & 1789.43 & 1.021 & - & - & - & - & - & $0.011 \pm 0.01$ \\
\hline Dodecane & $\mathrm{C}_{12} \mathrm{H}_{26}$ & 1869.41 & 1.038 & - & $(4.5 \pm 3.7) \times 10^{-3}$ & - & - & - & $0.088 \pm 0.018$ \\
\hline $\mathrm{C}_{13} \mathrm{H}_{28}$ isomer & $\mathrm{C}_{13} \mathrm{H}_{28}$ & $\begin{array}{r}1909.4 \\
\end{array}$ & 1.021 & - & $(1.8 \pm 2.0) \times 10^{-3}$ & - & - & $(3.8 \pm 4.3) \times 10^{-4}$ & $0.035 \pm 0.018$ \\
\hline Tridecane & $\mathrm{C}_{13} \mathrm{H}_{28}$ & 2089.34 & 1.052 & $(2.8 \pm 2.2) \times 10^{-3}$ & $(3.9 \pm 2.0) \times 10^{-3}$ & - & - & $(8.4 \pm 4.3) \times 10^{-4}$ & $0.058 \pm 0.012$ \\
\hline Tetradecane & $\mathrm{C}_{14} \mathrm{H}_{30}$ & 2299.27 & 1.06 & $(2.0+2.2) \times 10$ & - & - & - & $(4.5 \pm 2.2) \times 10^{-4}$ & $0.026 \pm 0.005$ \\
\hline $\mathrm{C}_{15} \mathrm{H}_{32}$ isomer & $\mathrm{C}_{15} \mathrm{H}_{32}$ & 2259.28 & 1.03 & - & - & - & - & (7.0 +2.2$) \wedge 10$ & $0.019 \pm 0.01$ \\
\hline $\mathrm{C}_{15} \mathrm{H}_{32}$ isomer & $\mathrm{C}_{15} \mathrm{H}_{32}$ & 2424.23 & 1.038 & - & - & - & - & - & $0.016 \pm 0.008$ \\
\hline Pentadecane & $\mathrm{C}_{15} \mathrm{H}_{32}$ & 2489.21 & 1.074 & - & - & - & - & - & $(9.1 \pm 2.0) \times 10^{-3}$ \\
\hline \multicolumn{10}{|l|}{$1 \mathrm{DBE}$} \\
\hline 1-Butene, 3-methyl- & $\mathrm{C}_{5} \mathrm{H}_{10}$ & 149.958 & 0.906 & $0.032 \pm 0.006$ & $0.037 \pm 0.007$ & $(2.5 \pm 0.5) \times 10^{-3}$ & $(1.8 \pm 0.4) \times 10^{-3}$ & $(8.7 \pm 1.7) \times 10^{-3}$ & $0.056 \pm 0.011$ \\
\hline 1-Pentene & $\mathrm{C}_{5} \mathrm{H}_{10}$ & 169.952 & 0.924 & $0.030 \pm 0.006$ & $0.038 \pm 0.008$ & - & $(7.6 \pm 1.5) \times 10^{-3}$ & $(8.0 \pm 1.6) \times 10^{-3}$ & $0.10 \pm 0.02$ \\
\hline 2-Methyl-1-butene & $\mathrm{C}_{5} \mathrm{H}_{10}$ & 174.95 & 0.933 & $\begin{array}{r}0.050+0.000 \\
-\end{array}$ & $0.041 \pm 0.008$ & $(5.5 \pm 1.1) \times 10^{-3}$ & 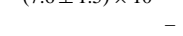 & $0.013 \pm 0.003$ & $0.13 \pm 0.03$ \\
\hline 2-Pentene, (E)- & $\mathrm{C}_{5} \mathrm{H}_{10}$ & 184.947 & 0.937 & $0.022 \pm 0.004$ & $0.053 \pm 0.011$ & $(3.2 \pm 0.6) \times 10^{-3}$ & $(4.5 \pm 0.9) \times 10^{-3}$ & $0.015 \pm 0.003$ & $0.12 \pm 0.02$ \\
\hline 2-Pentene, (Z)- & $\mathrm{C}_{5} \mathrm{H}_{10}$ & 194.944 & 0.95 & $0.072 \pm 0.014$ & $0.076 \pm 0.015$ & $(5.1 \pm 1.0) \times 10^{-3}$ & $(4.0 \pm 0.8) \times 10^{-3}$ & $0.018 \pm 0.004$ & $0.23 \pm 0.05$ \\
\hline Cyclopentane & $\begin{array}{l}\mathrm{C}_{5} \mathrm{H}_{10} \\
\mathrm{C}_{10}\end{array}$ & 244.928 & 0.977 & $\begin{array}{r}0.072 \pm 0.014 \\
-\end{array}$ & $(2.7 \pm 2.2) \times 10^{-3}$ & $(3.1 \pm 1.0) \times 10$ & $(5.3 \pm 9.4) \times 10^{-4}$ & $(3.2 \pm 4.6) \times 10^{-4}$ & $(4.6 \pm 0.9) \times 10^{-3}$ \\
\hline 1-Pentene, 4-methyl- & $\mathrm{C}_{6} \mathrm{H}_{12}$ & 234.931 & 0.959 & $(4.7 \pm 0.9) \times 10^{-3}$ & $(7.5 \pm 1.5) \times 10^{-3}$ & $(4.8 \pm 1.0) \times 10^{-4}$ & $(4.7 \pm 0.9) \times 10^{-4}$ & $(2.6 \pm 0.5) \times 10^{-3}$ & $0.032 \pm 0.006$ \\
\hline 1-Butene, 2,3-dimethyl- & $\mathrm{C}_{6} \mathrm{H}_{12}$ & 249.926 & 0.968 & $0.014 \pm 0.003$ & $0.023 \pm 0.005$ & $(7.6 \pm 9.3) \times 10^{-4}$ & $(1.3 \pm 13.9) \times 10^{-4}$ & $(6.1 \pm 1.2) \times 10^{-3}$ & $0.053 \pm 0.011$ \\
\hline 1-Hexene & $\mathrm{C}_{6} \mathrm{H}_{12}$ & 284.915 & 0.994 & $0.12 \pm 0.02$ & $0.16 \pm 0.03$ & $(3.2 \pm 1.2) \times 10^{-3}$ & $(5.4 \pm 1.8) \times 10^{-3}$ & $0.024 \pm 0.005$ & $0.36 \pm 0.07$ \\
\hline 2-Hexene, (E)- & $\mathrm{C}_{6} \mathrm{H}_{12}$ & 309.907 & 1.003 & $(6.5 \pm 1.3) \times 10^{-3}$ & $0.012 \pm 0.002$ & $(6.9 \pm 1.4) \times 10^{-4}$ & $(8.7 \pm 1.7) \times 10^{-4}$ & $(3.4 \pm 0.7) \times 10^{-3}$ & $0.059 \pm 0.012$ \\
\hline 2-Pentene, 2-methyl- & $\mathrm{C}_{6} \mathrm{H}_{12}$ & 314.906 & 1.012 & $0.025 \pm 0.005$ & $0.033 \pm 0.007$ & $(8.9 \pm 1.8) \times 10^{-4}$ & $(5.6 \pm 1.1) \times 10^{-4}$ & $(7.4 \pm 1.5) \times 10^{-3}$ & $0.049 \pm 0.01$ \\
\hline 2-Pentene, 3-methyl-, (Z)- & $\mathrm{C}_{6} \mathrm{H}_{12}$ & 324.902 & 1.021 & $\begin{array}{r}0.025+0.003 \\
-\end{array}$ & $0.012 \pm 0.006$ & $(5.7 \pm 2.8) \times 10^{-4}$ & $(3.0+1.1) \times 10$ & $(4.1 \pm 2.0) \times 10^{-3}$ & - \\
\hline 2-Hexene, (Z)- & $\mathrm{C}_{6} \mathrm{H}_{12}$ & 329.901 & 1.016 & - & $0.012+0.000$ & (5.) & $(6.3 \pm 1.7) \times 10^{-4}$ & $(+.1+2.0) \times 10$ & $0.026 \pm 0.005$ \\
\hline 2-Pentene, 3-methyl-, (E)- & $\mathrm{C}_{6} \mathrm{H}_{12}$ & 344.896 & 1.025 & $(6.3 \pm 3.1) \times 10^{-3}$ & $0.013 \pm 0.006$ & $(4.7 \pm 2.4) \times 10^{-4}$ & $(4.4 \pm 2.2) \times 10^{-4}$ & $(3.6 \pm 1.8) \times 10^{-3}$ & $0.017 \pm 0.008$ \\
\hline Cyclopentane, methyl- & $\mathrm{C}_{6} \mathrm{H}_{12}$ & 359.891 & 1.012 & $(2.9 \pm 0.6) \times 10^{-3}$ & $(7.8 \pm 1.6) \times 10^{-3}$ & $(1.7+2.7) \times 10$ & $(3.0 \pm 2.4) \times 10^{-4}$ & $(7.0 \pm 1.4) \times 10^{-4}$ & $0.024 \pm 0.005$ \\
\hline 2-Pentene, 4-methyl- & $\mathrm{C}_{6} \mathrm{H}_{12}$ & 369.888 & 1.038 & $(8.0 \pm 4.0) \times 10^{-4}$ & $(1.2 \pm 0.6) \times 10^{-3}$ & - & - & $(2.6 \pm 1.3) \times 10^{-4}$ & $(7.1 \pm 3.6) \times 10^{-3}$ \\
\hline Cyclohexane & $\mathrm{C}_{6} \mathrm{H}_{12}$ & 434.867 & 1.043 & $(0.0+40)=10$ & $(1.2+0.0) \times 10$ & $(1.4 \pm 0.3) \times 10^{-4}$ & $(1.5 \pm 0.3) \times 10^{-4}$ & - & $(6.3 \pm 3.8) \times 10^{-3}$ \\
\hline 1-Hexene, 3-methyl- & $\mathrm{C}_{7} \mathrm{H}_{14}$ & 414.874 & 1.008 & - & $(1.6 \pm 0.8) \times 10^{-3}$ & (1.) & (10) & $(3.5 \pm 1.7) \times 10^{-4}$ & $(7.1 \pm 3.6) \times 10^{-3}$ \\
\hline 1-Hexene, 5-methyl- & $\mathrm{C}_{7} \mathrm{H}_{14}$ & 429.869 & 1.016 & - & $(2.2 \pm 1.1) \times 10^{-3}$ & - & - & $(3.7 \pm 1.8) \times 10^{-4}$ & $(6.5 \pm 3.2) \times 10^{-3}$ \\
\hline 1-Pentene, 2,3-dimethyl- & $\mathrm{C}_{7} \mathrm{H}_{14}$ & 434.867 & 1.025 & - & - & - & - & $(3.7 \pm 1.8) \times 10^{-4}$ & - \\
\hline
\end{tabular}


Table A1. Continued.

\begin{tabular}{|c|c|c|c|c|c|c|c|c|c|}
\hline 1-Butene, 2-ethyl, 3-methyl & $\mathrm{C}_{7} \mathrm{H}_{14}$ & 449.862 & 1.021 & $(3.6 \pm 1.8) \times 10^{-3}$ & $(5.6 \pm 2.8) \times 10^{-3}$ & - & & $-\quad(2.1 \pm 1.1) \times 10^{-3}$ & $0.016 \pm 0.008$ \\
\hline 2-Hexene, 5-methyl-, (E)- & $\mathrm{C}_{7} \mathrm{H}_{14}$ & 484.851 & 1.03 & - & - & - & & - & $(4.5 \pm 2.3) \times 10^{-3}$ \\
\hline 1-Heptene & $\mathrm{C}_{7} \mathrm{H}_{14}$ & 509.843 & 1.034 & $0.062 \pm 0.012$ & $0.069 \pm 0.014$ & $(1.3 \pm 0.3) \times 10^{-3}$ & $(2.3 \pm 0.5) \times 10^{-3}$ & $0.013 \pm 0.003$ & $0.22 \pm 0.04$ \\
\hline 3-Heptene, (E)- & $\mathrm{C}_{7} \mathrm{H}_{14}$ & 529.837 & 1.025 & $(5.9 \pm 8.3) \times 10^{-4}$ & $(1.9 \pm 1.0) \times 10^{-3}$ & - & & $(1.4 \pm 2.2) \times 10^{-4}$ & $0.016 \pm 0.003$ \\
\hline (Z)-3-Methyl-2-hexene & $\mathrm{C}_{7} \mathrm{H}_{14}$ & 544.832 & 1.038 & $(2.4 \pm 1.2) \times 10^{-3}$ & $(2.6 \pm 1.3) \times 10^{-3}$ & - & & $-\quad(1.5 \pm 0.8) \times 10^{-3}$ & - \\
\hline 2-Heptene, (E)- & $\mathrm{C}_{7} \mathrm{H}_{14}$ & 554.829 & 1.038 & $(4.3 \pm 0.9) \times 10^{-3}$ & $0.016 \pm 0.003$ & - & & - & $0.054 \pm 0.011$ \\
\hline 3-Methyl-2-hexene (E) & $\mathrm{C}_{7} \mathrm{H}_{14}$ & 564.826 & 1.047 & $(1.0 \pm 0.5) \times 10^{-3}$ & $(1.6 \pm 0.8) \times 10^{-3}$ & - & & $-\quad(7.3 \pm 3.6) \times 10^{-4}$ & $(4.5 \pm 2.3) \times 10^{-3}$ \\
\hline 2-Heptene, (Z) & $\mathrm{C}_{7} \mathrm{H}_{14}$ & 574.822 & 1.047 & $(2.9 \pm 0.6) \times 10^{-3}$ & $(4.8 \pm 1.0) \times 10^{-3}$ & - & & $-\quad(3.4 \pm 1.2) \times 10^{-4}$ & $0.028 \pm 0.006$ \\
\hline $\mathrm{C}_{7} \mathrm{H}_{14}$ isomer & $\mathrm{C}_{7} \mathrm{H}_{14}$ & 579.821 & 1.052 & - & - & - & & $-\quad(3.5 \pm 1.8) \times 10^{-4}$ & - \\
\hline Cyclohexane, methyl- & $\mathrm{C}_{7} \mathrm{H}_{14}$ & 599.814 & 1.052 & - & $(3.3 \pm 1.3) \times 10^{-3}$ & - & & - & $0.017 \pm 0.004$ \\
\hline Cyclopentane, ethyl- & $\mathrm{C}_{7} \mathrm{H}_{14}$ & 629.805 & 1.052 & - & $(4.9 \pm 1.0) \times 10^{-3}$ & - & & - $\quad(3.6 \pm 0.7) \times 10^{-4}$ & $0.021 \pm 0.004$ \\
\hline $\mathrm{C}_{8} \mathrm{H}_{16}$ isomer & $\mathrm{C}_{8} \mathrm{H}_{16}$ & 634.803 & 1.034 & - & - & - & & - & $(5.6 \pm 2.8) \times 10^{-3}$ \\
\hline 3-Heptene, 2-methyl-(Z) & $\mathrm{C}_{8} \mathrm{H}_{16}$ & 684.787 & 1.012 & - & - & - & & - & $(5.1 \pm 2.6) \times 10^{-3}$ \\
\hline 1-Hexene, 2,5-dimethyl- & $\mathrm{C}_{8} \mathrm{H}_{16}$ & 699.782 & 1.025 & $(1.2 \pm 0.6) \times 10^{-3}$ & $(1.6 \pm 0.8) \times 10^{-3}$ & - & & $-\quad(3.1 \pm 1.8) \times 10^{-4}$ & $0.014 \pm 0.007$ \\
\hline 3-Heptene, 2-methyl-, (E)- & $\mathrm{C}_{8} \mathrm{H}_{16}$ & 719.776 & 1.038 & $(1.4 \pm 0.7) \times 10^{-3}$ & - & - & & - & $(3.9 \pm 2.0) \times 10^{-3}$ \\
\hline 2-Heptene, 6-methyl- (E) & $\mathrm{C}_{8} \mathrm{H}_{16}$ & 744.768 & 1.043 & - & - & - & & $-\quad(5.0 \pm 2.5) \times 10^{-4}$ & $(8.1 \pm 4.1) \times 10^{-3}$ \\
\hline Cyclohexane, 1,4-dimethyl- & $\mathrm{C}_{8} \mathrm{H}_{16}$ & 764.762 & 1.047 & $(1.2 \pm 0.2) \times 10^{-3}$ & $(2.5 \pm 0.5) \times 10^{-3}$ & - & & $-\quad(4.6 \pm 0.9) \times 10^{-4}$ & $(9.8 \pm 4.9) \times 10^{-3}$ \\
\hline 1-Heptene, 2-methyl- & $\mathrm{C}_{8} \mathrm{H}_{16}$ & 784.755 & 1.052 & - & $(1.8 \pm 0.9) \times 10^{-3}$ & - & & $-\quad(1.8 \pm 1.8) \times 10^{-4}$ & $(7.9 \pm 4.0) \times 10^{-3}$ \\
\hline 1-Octene & $\mathrm{C}_{8} \mathrm{H}_{16}$ & 799.75 & 1.047 & $0.033 \pm 0.007$ & $0.054 \pm 0.011$ & $(1.1 \pm 0.3) \times 10^{-3}$ & $(2.1 \pm 0.5) \times 10^{-3}$ & 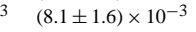 & $0.19 \pm 0.04$ \\
\hline 3-Octene, (E)- & $\mathrm{C}_{8} \mathrm{H}_{16}$ & 819.744 & 1.043 & $(1.7 \pm 0.8) \times 10^{-3}$ & $(2.0 \pm 1.0) \times 10^{-3}$ & - & & - & $0.010 \pm 0.005$ \\
\hline 2-Methyl-2-heptene & $\mathrm{C}_{8} \mathrm{H}_{16}$ & 824.742 & 1.056 & $(1.6 \pm 0.8) \times 10^{-3}$ & $(1.8 \pm 0.9) \times 10^{-3}$ & - & & $-\quad(4.3 \pm 2.2) \times 10^{-4}$ & $0.012 \pm 0.006$ \\
\hline 2-Octene, (E)- & $\mathrm{C}_{8} \mathrm{H}_{16}$ & 839.738 & 1.052 & $(3.4 \pm 0.7) \times 10^{-3}$ & $(6.5 \pm 1.3) \times 10^{-3}$ & - & & $-\quad(4.7 \pm 0.9) \times 10^{-4}$ & $0.025 \pm 0.005$ \\
\hline Cyclohexane, 1,3-dimethyl-, trans- & $\mathrm{C}_{8} \mathrm{H}_{16}$ & 844.736 & 1.065 & - & - & - & & - & $(3.0 \pm 1.5) \times 10^{-3}$ \\
\hline 2-Octene, (Z)- & $\mathrm{C}_{8} \mathrm{H}_{16}$ & 864.73 & 1.06 & $(1.9 \pm 0.4) \times 10^{-3}$ & $(3.2 \pm 0.6) \times 10^{-3}$ & - & & $-\quad(2.0 \pm 0.6) \times 10^{-4}$ & $0.016 \pm 0.003$ \\
\hline Cyclopentane, 1-ethyl-2-methyl-, cis- & $\mathrm{C}_{8} \mathrm{H}_{16}$ & 889.722 & 1.069 & - & - & - & & - & $(2.5 \pm 1.3) \times 10^{-3}$ \\
\hline 1-Pentene, 3-ethyl-3-methyl- & $\mathrm{C}_{8} \mathrm{H}_{16}$ & 914.714 & 1.021 & - & - & - & & - & $(3.6 \pm 1.8) \times 10^{-3}$ \\
\hline Cyclopentane, propyl- & $\mathrm{C}_{8} \mathrm{H}_{16}$ & 919.712 & 1.069 & $(6.6 \pm 2.2) \times 10^{-4}$ & $(2.2 \pm 0.4) \times 10^{-3}$ & - & & - & $(9.0 \pm 1.8) \times 10^{-3}$ \\
\hline Cyclohexane, ethyl- & $\mathrm{C}_{8} \mathrm{H}_{16}$ & 924.71 & 1.082 & $(5.9 \pm 3.0) \times 10^{-4}$ & $(1.4 \pm 0.7) \times 10^{-3}$ & - & & - & $0.010 \pm 0.005$ \\
\hline $\mathrm{C}_{8} \mathrm{H}_{16}$ isomer & $\mathrm{C}_{8} \mathrm{H}_{16}$ & 1034.68 & 1.065 & - & - & - & & - & $(4.6 \pm 2.3) \times 10^{-3}$ \\
\hline Cyclohexane, 1,1,3-trimethyl- & $\mathrm{C}_{9} \mathrm{H}_{18}$ & 944.704 & 1.047 & - & - & - & & - & $0.013 \pm 0.006$ \\
\hline $\mathrm{C}_{9} \mathrm{H}_{18}$ isomer & $\mathrm{C}_{9} \mathrm{H}_{18}$ & 974.694 & 1.043 & $(1.2 \pm 0.6) \times 10^{-3}$ & - & - & & $-\quad(1.2 \pm 0.6) \times 10^{-3}$ & $0.023 \pm 0.011$ \\
\hline $\mathrm{C}_{9} \mathrm{H}_{18}$ isomer & $\mathrm{C}_{9} \mathrm{H}_{18}$ & 1009.68 & 1.052 & $(1.1 \pm 0.6) \times 10^{-3}$ & - & - & & - & $0.021 \pm 0.01$ \\
\hline 4-Nonene, (E) & $\mathrm{C}_{9} \mathrm{H}_{18}$ & 1074.66 & 1.056 & - & $(1.9 \pm 1.0) \times 10^{-3}$ & - & & - & $(9.6 \pm 4.8) \times 10^{-3}$ \\
\hline 1-Nonene & $\mathrm{C}_{9} \mathrm{H}_{18}$ & 1089.66 & 1.06 & $0.023 \pm 0.005$ & $0.035 \pm 0.007$ & $(1.1 \pm 0.5) \times 10^{-3}$ & $(9.3 \pm 7.6) \times 10^{-4}$ & $(6.4 \pm 1.3) \times 10^{-3}$ & $0.14 \pm 0.03$ \\
\hline cis-4-Nonene & $\mathrm{C}_{9} \mathrm{H}_{18}$ & 1099.65 & 1.052 & $(1.0 \pm 0.5) \times 10^{-3}$ & $(2.5 \pm 1.2) \times 10^{-3}$ & - & & - & $0.015 \pm 0.007$ \\
\hline 2-Nonene, (E)- & $\mathrm{C}_{9} \mathrm{H}_{18}$ & 1124.65 & 1.065 & $(1.7 \pm 0.3) \times 10^{-3}$ & $(3.2 \pm 0.6) \times 10^{-3}$ & - & & - & $0.021 \pm 0.004$ \\
\hline cis-2-Nonene & $\mathrm{C}_{9} \mathrm{H}_{18}$ & 1149.64 & 1.074 & - & $(2.3 \pm 0.5) \times 10^{-3}$ & - & & - & $0.011 \pm 0.002$ \\
\hline Cyclopentane, butyl- & $\mathrm{C}_{9} \mathrm{H}_{18}$ & 1209.62 & 1.078 & $(1.7 \pm 1.2) \times 10^{-3}$ & $(2.8 \pm 0.6) \times 10^{-3}$ & - & & - & $0.015 \pm 0.003$ \\
\hline $\mathrm{C}_{9} \mathrm{H}_{18}$ isomer & $\mathrm{C}_{9} \mathrm{H}_{18}$ & 1249.61 & 1.056 & $(9.3 \pm 4.7) \times 10^{-4}$ & $(1.4 \pm 0.7) \times 10^{-3}$ & - & & - & $(8.7 \pm 4.3) \times 10^{-3}$ \\
\hline $\mathrm{C}_{9} \mathrm{H}_{18}$ isomer & $\mathrm{C}_{9} \mathrm{H}_{18}$ & 1279.6 & 1.074 & - & - & - & & - & $(4.9 \pm 2.5) \times 10^{-3}$ \\
\hline $\mathrm{C}_{10} \mathrm{H}_{20}$ isomer & $\mathrm{C}_{10} \mathrm{H}_{20}$ & 1144.64 & 1.03 & - & - & - & & $-\quad(3.1 \pm 4.6) \times 10^{-4}$ & $0.019 \pm 0.01$ \\
\hline $\mathrm{C}_{10} \mathrm{H}_{20}$ isomer & $\mathrm{C}_{10} \mathrm{H}_{20}$ & 1269.6 & 1.056 & - & - & - & & - & $0.013 \pm 0.007$ \\
\hline $\mathrm{C}_{10} \mathrm{H}_{20}$ isomer & $\mathrm{C}_{10} \mathrm{H}_{20}$ & 1299.59 & 1.06 & - & - & - & & - & $0.012 \pm 0.006$ \\
\hline $\mathrm{C}_{10} \mathrm{H}_{20}$ isomer & $\mathrm{C}_{10} \mathrm{H}_{20}$ & 1349.57 & 1.065 & - & $(1.6 \pm 0.8) \times 10^{-3}$ & - & & - & $0.013 \pm 0.006$ \\
\hline 1-Decene & $\mathrm{C}_{10} \mathrm{H}_{20}$ & 1359.57 & 1.074 & $0.023 \pm 0.005$ & $0.037 \pm 0.007$ & $(2.2 \pm 0.6) \times 10^{-3}$ & & $-\quad(7.2 \pm 1.4) \times 10^{-3}$ & $0.13 \pm 0.03$ \\
\hline $\mathrm{C}_{10} \mathrm{H}_{20}$ isomer & $\mathrm{C}_{10} \mathrm{H}_{20}$ & 1394.56 & 1.074 & $(2.4 \pm 1.2) \times 10^{-3}$ & $(3.5 \pm 2.2) \times 10^{-3}$ & - & & $-\quad(1.6 \pm 4.6) \times 10^{-4}$ & $0.023 \pm 0.012$ \\
\hline $\mathrm{C}_{10} \mathrm{H}_{20}$ isomer & $\mathrm{C}_{10} \mathrm{H}_{20}$ & 1419.55 & 1.082 & - & $(2.2 \pm 1.1) \times 10^{-3}$ & - & & - & $0.020 \pm 0.01$ \\
\hline $\mathrm{C}_{10} \mathrm{H}_{20}$ isomer & $\mathrm{C}_{10} \mathrm{H}_{20}$ & 1479.53 & 1.109 & - & $(3.2 \pm 1.6) \times 10^{-3}$ & - & & - & $0.010 \pm 0.006$ \\
\hline $\mathrm{C}_{10} \mathrm{H}_{20}$ isomer & $\mathrm{C}_{10} \mathrm{H}_{20}$ & 1499.53 & 1.06 & - & - & - & & - & $(6.9 \pm 3.5) \times 10^{-3}$ \\
\hline $\mathrm{C}_{10} \mathrm{H}_{20}$ isomer & $\mathrm{C}_{10} \mathrm{H}_{20}$ & 1589.5 & 1.052 & - & - & - & & - & $(6.4 \pm 3.2) \times 10^{-3}$ \\
\hline $\mathrm{C}_{11} \mathrm{H}_{22}$ isomer & $\mathrm{C}_{11} \mathrm{H}_{22}$ & 1429.55 & 1.047 & - & - & - & & $-\quad(1.6 \pm 0.8) \times 10^{-3}$ & $(6.4 \pm 6.1) \times 10^{-3}$ \\
\hline $\mathrm{C}_{11} \mathrm{H}_{22}$ Isomer & $\mathrm{C}_{11} \mathrm{H}_{22}$ & 1529.52 & 1.065 & - & - & - & & - & $(7.9 \pm 3.9) \times 10^{-3}$ \\
\hline $\mathrm{C}_{11} \mathrm{H}_{22}$ isomer & $\mathrm{C}_{11} \mathrm{H}_{22}$ & 1609.49 & 1.074 & - & $(1.7 \pm 0.9) \times 10^{-3}$ & - & & - & $(8.9 \pm 4.5) \times 10^{-3}$ \\
\hline 1-Undecene & $\mathrm{C}_{11} \mathrm{H}_{22}$ & 1614.49 & 1.087 & $0.013 \pm 0.007$ & $0.029 \pm 0.014$ & $(7.5 \pm 6.3) \times 10^{-4}$ & $(7.4 \pm 9.4) \times 10^{-4}$ & $4 \quad(4.4 \pm 2.2) \times 10^{-3}$ & $0.094 \pm 0.047$ \\
\hline $\mathrm{C}_{11} \mathrm{H}_{22}$ Isomer & $\mathrm{C}_{11} \mathrm{H}_{22}$ & 1629.48 & 1.082 & - & - & - & & - & $(4.4 \pm 2.2) \times 10^{-3}$ \\
\hline $\mathrm{C}_{11} \mathrm{H}_{22}$ isomer & $\mathrm{C}_{11} \mathrm{H}_{22}$ & 1644.48 & 1.091 & $(1.8 \pm 1.8) \times 10^{-3}$ & $(4.8 \pm 2.4) \times 10^{-3}$ & - & & - & $0.016 \pm 0.008$ \\
\hline $\mathrm{C}_{11} \mathrm{H}_{22}$ isomer & $\mathrm{C}_{11} \mathrm{H}_{22}$ & 1669.47 & 1.1 & - & $(2.2 \pm 1.1) \times 10^{-3}$ & - & & - & $(8.1 \pm 6.1) \times 10^{-3}$ \\
\hline $\mathrm{C}_{11} \mathrm{H}_{22}$ isomer & $\mathrm{C}_{11} \mathrm{H}_{22}$ & 1739.45 & 1.113 & - & $(1.9 \pm 0.9) \times 10^{-3}$ & - & & - & - \\
\hline $\mathrm{C}_{12} \mathrm{H}_{24}$ isomer & $\mathrm{C}_{12} \mathrm{H}_{24}$ & 1844.42 & 1.087 & - & - & - & & - & $0.012 \pm 0.007$ \\
\hline 1-Dodecene & $\mathrm{C}_{12} \mathrm{H}_{24}$ & 1854.41 & 1.096 & $0.013 \pm 0.003$ & $0.014 \pm 0.003$ & - & & $-\quad(4.3 \pm 0.9) \times 10^{-3}$ & $0.098 \pm 0.02$ \\
\hline $\mathrm{C}_{12} \mathrm{H}_{24}$ isomer & $\mathrm{C}_{12} \mathrm{H}_{24}$ & 1879.4 & 1.1 & - & $(3.3 \pm 2.3) \times 10^{-3}$ & - & & - & $0.021 \pm 0.01$ \\
\hline $\mathrm{C}_{12} \mathrm{H}_{24}$ isomer & $\mathrm{C}_{12} \mathrm{H}_{24}$ & 1884.4 & 1.109 & - & - & - & & - & $0.013 \pm 0.007$ \\
\hline $\mathrm{C}_{12} \mathrm{H}_{24}$ isomer & $\mathrm{C}_{12} \mathrm{H}_{24}$ & 1904.4 & 1.109 & - & - & - & & - & $0.017 \pm 0.008$ \\
\hline $\mathrm{C}_{12} \mathrm{H}_{24}$ isomer & $\mathrm{C}_{12} \mathrm{H}_{24}$ & 1919.39 & 1.074 & - & - & - & & - & $0.011 \pm 0.007$ \\
\hline $\mathrm{C}_{12} \mathrm{H}_{24}$ isomer & $\mathrm{C}_{12} \mathrm{H}_{24}$ & 1974.37 & 1.135 & - & - & - & & - & $0.010 \pm 0.007$ \\
\hline $\mathrm{C}_{13} \mathrm{H}_{26}$ isomer & $\mathrm{C}_{13} \mathrm{H}_{26}$ & 2069.34 & 1.096 & - & - & - & & - & $0.015 \pm 0.007$ \\
\hline 1-Tridecene & $\mathrm{C}_{13} \mathrm{H}_{26}$ & 2074.34 & 1.104 & $(6.7 \pm 3.4) \times 10^{-3}$ & $(8.9 \pm 4.4) \times 10^{-3}$ & - & & $-\quad(2.8 \pm 1.4) \times 10^{-3}$ & $0.053 \pm 0.027$ \\
\hline $\mathrm{C}_{13} \mathrm{H}_{26}$ isomer & $\mathrm{C}_{13} \mathrm{H}_{26}$ & 2099.33 & 1.109 & - & - & - & & - & $0.011 \pm 0.007$ \\
\hline $\mathrm{C}_{13} \mathrm{H}_{26}$ isomer & $\mathrm{C}_{13} \mathrm{H}_{26}$ & 2124.33 & 1.122 & - & - & - & & - & $(9.6 \pm 6.6) \times 10^{-3}$ \\
\hline $\mathrm{C}_{13} \mathrm{H}_{26}$ isomer & $\mathrm{C}_{13} \mathrm{H}_{26}$ & 2209.3 & 1.069 & - & - & - & & $-\quad(1.6 \pm 0.8) \times 10^{-3}$ & - \\
\hline $\mathrm{C}_{14} \mathrm{H}_{28}$ isomer & $\mathrm{C}_{14} \mathrm{H}_{28}$ & 2109.33 & 1.082 & - & - & - & & - & $0.019 \pm 0.01$ \\
\hline 1-Tetradecene & $\mathrm{C}_{14} \mathrm{H}_{28}$ & 2284.28 & 1.118 & $(5.4 \pm 1.6) \times 10^{-3}$ & - & - & & $-\quad(2.4 \pm 0.5) \times 10^{-3}$ & $0.039 \pm 0.008$ \\
\hline 1-Pentadecene & $\mathrm{C}_{15} \mathrm{H}_{30}$ & 2479.21 & 1.126 & - & - & - & & - & $0.016 \pm 0.008$ \\
\hline
\end{tabular}


Table A1. Continued.

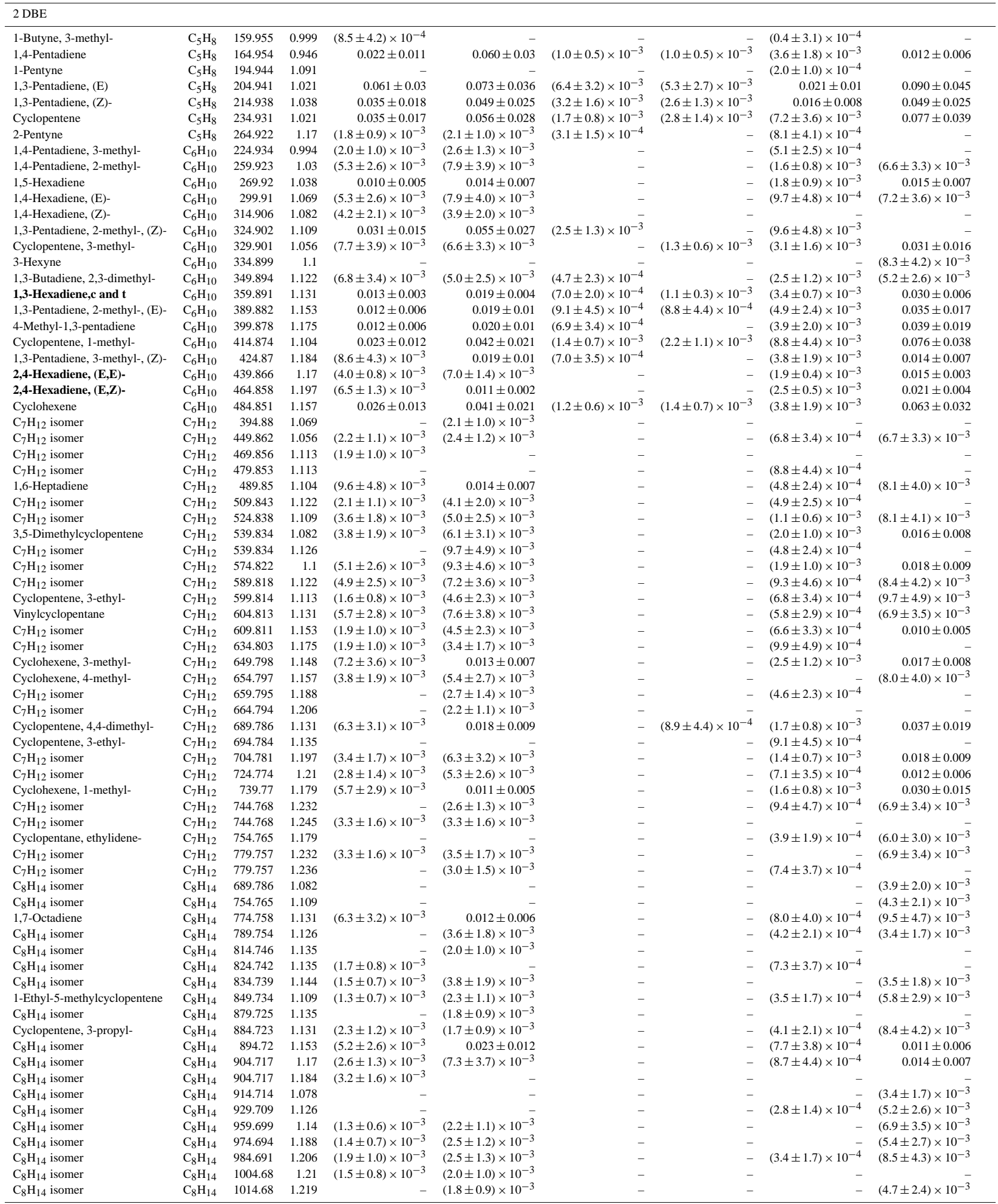


Table A1. Continued.

\begin{tabular}{|c|c|c|c|c|c|c|c|c|c|}
\hline Cyclohexane, ethylidene- & $\mathrm{C}_{8} \mathrm{H}_{14}$ & 1024.68 & 1.197 & - & $(2.7 \pm 1.3) \times 10^{-3}$ & - & - & - & $(7.6 \pm 3.8) \times 10^{-3}$ \\
\hline $\mathrm{C}_{8} \mathrm{H}_{14}$ isomer & $\mathrm{C}_{8} \mathrm{H}_{14}$ & 1039.67 & 1.219 & - & - & - & - & - & $(3.8 \pm 1.9) \times 10^{-3}$ \\
\hline $\mathrm{C}_{8} \mathrm{H}_{14}$ isomer & $\mathrm{C}_{8} \mathrm{H}_{14}$ & 1099.65 & 1.153 & - & $(3.5 \pm 1.7) \times 10^{-3}$ & - & - & - & - \\
\hline $\mathrm{C}_{9} \mathrm{H}_{16}$ isomer & $\mathrm{C}_{9} \mathrm{H}_{16}$ & 999.686 & 1.109 & $(3.6 \pm 10.0) \times 10^{-4}$ & $(2.5 \pm 1.3) \times 10^{-3}$ & - & - & - & - \\
\hline $\mathrm{C}_{9} \mathrm{H}_{16}$ isomer & $\mathrm{C}_{9} \mathrm{H}_{16}$ & 1009.68 & 1.122 & - & $(1.3 \pm 0.6) \times 10^{-3}$ & - & - & - & - \\
\hline $\mathrm{C}_{9} \mathrm{H}_{16}$ isomer & $\mathrm{C}_{9} \mathrm{H}_{16}$ & 1019.68 & 1.122 & - & - & - & - & - & $(9.5 \pm 4.8) \times 10^{-3}$ \\
\hline $\mathrm{C}_{9} \mathrm{H}_{16}$ isomer & $\mathrm{C}_{9} \mathrm{H}_{16}$ & 1054.67 & 1.126 & $(2.2 \pm 1.1) \times 10^{-3}$ & $(5.2 \pm 2.6) \times 10^{-3}$ & - & - & $(3.1 \pm 2.6) \times 10^{-4}$ & - \\
\hline 1,8-Nonadiene & $\mathrm{C}_{9} \mathrm{H}_{16}$ & 1064.67 & 1.144 & $(7.4 \pm 3.7) \times 10^{-3}$ & $0.013 \pm 0.007$ & - & - & $(7.4 \pm 3.7) \times 10^{-4}$ & $(8.1 \pm 4.0) \times 10^{-3}$ \\
\hline $\mathrm{C}_{9} \mathrm{H}_{16}$ isomer & $\mathrm{C}_{9} \mathrm{H}_{16}$ & 1079.66 & 1.126 & - & $(1.7 \pm 1.2) \times 10^{-3}$ & - & - & $(5.2 \pm 2.6) \times 10^{-4}$ & $(4.7 \pm 2.3) \times 10^{-3}$ \\
\hline $\mathrm{C}_{9} \mathrm{H}_{16}$ isomer & $\mathrm{C}_{9} \mathrm{H}_{16}$ & 1089.66 & 1.148 & - & $(2.5 \pm 1.3) \times 10^{-3}$ & - & - & - & - \\
\hline $\mathrm{C}_{9} \mathrm{H}_{16}$ isomer & $\mathrm{C}_{9} \mathrm{H}_{16}$ & 1099.65 & 1.148 & - & - & - & - & - & $(4.8 \pm 2.4) \times 10^{-3}$ \\
\hline $\mathrm{C}_{9} \mathrm{H}_{16}$ isomer & $\mathrm{C}_{9} \mathrm{H}_{16}$ & 1124.65 & 1.157 & - & $(2.6 \pm 1.3) \times 10^{-3}$ & - & - & - & $(6.4 \pm 3.2) \times 10^{-3}$ \\
\hline $\mathrm{C}_{9} \mathrm{H}_{16}$ isomer & $\mathrm{C}_{9} \mathrm{H}_{16}$ & 1139.64 & 1.157 & - & $(1.9 \pm 0.9) \times 10^{-3}$ & - & - & - & - \\
\hline $\mathrm{C}_{9} \mathrm{H}_{16}$ isomer & $\mathrm{C}_{9} \mathrm{H}_{16}$ & 1144.64 & 1.166 & $(1.8 \pm 1.0) \times 10^{-3}$ & $(3.3 \pm 1.6) \times 10^{-3}$ & - & - & $(4.5 \pm 2.6) \times 10^{-4}$ & $0.014 \pm 0.007$ \\
\hline $\mathrm{C}_{9} \mathrm{H}_{16}$ isomer & $\mathrm{C}_{9} \mathrm{H}_{16}$ & 1164.63 & 1.166 & - & $(2.0 \pm 1.0) \times 10^{-3}$ & - & - & - & - \\
\hline $\mathrm{C}_{9} \mathrm{H}_{16}$ isomer & $\mathrm{C}_{9} \mathrm{H}_{16}$ & 1169.63 & 1.175 & - & $(2.3 \pm 1.2) \times 10^{-3}$ & - & - & - & $(8.5 \pm 4.2) \times 10^{-3}$ \\
\hline $\mathrm{C}_{9} \mathrm{H}_{16}$ isomer & $\mathrm{C}_{9} \mathrm{H}_{16}$ & 1189.63 & 1.184 & - & $(6.0 \pm 3.0) \times 10^{-3}$ & - & - & $(3.2 \pm 2.6) \times 10^{-4}$ & $(8.0 \pm 4.0) \times 10^{-3}$ \\
\hline $\mathrm{C}_{9} \mathrm{H}_{16}$ isomer & $\mathrm{C}_{9} \mathrm{H}_{16}$ & 1239.61 & 1.192 & - & $(6.3 \pm 3.1) \times 10^{-3}$ & - & - & - & - \\
\hline $\mathrm{C}_{9} \mathrm{H}_{16}$ isomer & $\mathrm{C}_{9} \mathrm{H}_{16}$ & 1244.61 & 1.153 & - & - & - & - & - & $(8.8 \pm 4.4) \times 10^{-3}$ \\
\hline $\mathrm{C}_{9} \mathrm{H}_{16}$ isomer & $\mathrm{C}_{9} \mathrm{H}_{16}$ & 1254.6 & 1.197 & - & - & - & - & - & $(6.0 \pm 3.0) \times 10^{-3}$ \\
\hline $\mathrm{C}_{9} \mathrm{H}_{16}$ isomer & $\mathrm{C}_{9} \mathrm{H}_{16}$ & 1274.6 & 1.197 & - & - & - & - & - & $(6.5 \pm 3.3) \times 10^{-3}$ \\
\hline $\mathrm{C}_{9} \mathrm{H}_{16}$ isomer & $\mathrm{C}_{9} \mathrm{H}_{16}$ & 1274.6 & 1.219 & - & $(2.5 \pm 1.3) \times 10^{-3}$ & - & - & - & - \\
\hline $\mathrm{C}_{10} \mathrm{H}_{18}$ isomer & $\mathrm{C}_{10} \mathrm{H}_{18}$ & 1199.62 & 1.109 & - & $(2.6 \pm 2.1) \times 10^{-3}$ & - & - & - & - \\
\hline $\mathrm{C}_{10} \mathrm{H}_{18}$ isomer & $\mathrm{C}_{10} \mathrm{H}_{18}$ & 1239.61 & 1.122 & $(1.3 \pm 0.7) \times 10^{-3}$ & - & - & - & - & - \\
\hline $\mathrm{C}_{10} \mathrm{H}_{18}$ isomer & $\mathrm{C}_{10} \mathrm{H}_{18}$ & 1299.59 & 1.14 & $(1.5 \pm 0.8) \times 10^{-3}$ & $(4.9 \pm 2.5) \times 10^{-3}$ & - & - & - & - \\
\hline $\mathrm{C}_{10} \mathrm{H}_{18}$ isomer & $\mathrm{C}_{10} \mathrm{H}_{18}$ & 1304.59 & 1.148 & $(2.2 \pm 1.1) \times 10^{-3}$ & - & - & - & - & $(8.1 \pm 4.1) \times 10^{-3}$ \\
\hline $\mathrm{C}_{10} \mathrm{H}_{18}$ isomer & $\mathrm{C}_{10} \mathrm{H}_{18}$ & 1329.58 & 1.144 & - & $(1.7 \pm 2.1) \times 10^{-3}$ & - & - & - & $0.012 \pm 0.006$ \\
\hline 1,9-Decadiene & $\mathrm{C}_{10} \mathrm{H}_{18}$ & 1339.58 & 1.153 & $(4.8 \pm 2.4) \times 10^{-3}$ & $0.012 \pm 0.006$ & - & $(7.5 \pm 4.6) \times 10^{-4}$ & $0.012 \pm 0.006$ & - \\
\hline $\mathrm{C}_{10} \mathrm{H}_{18}$ isomer & $\mathrm{C}_{10} \mathrm{H}_{18}$ & 1349.57 & 1.153 & $(2.4 \pm 1.8) \times 10^{-3}$ & $(5.7 \pm 2.8) \times 10^{-3}$ & - & - & - & $(8.2 \pm 4.1) \times 10^{-3}$ \\
\hline $\mathrm{C}_{10} \mathrm{H}_{18}$ isomer & $\mathrm{C}_{10} \mathrm{H}_{18}$ & 1364.57 & 1.166 & $(2.1 \pm 1.8) \times 10^{-3}$ & $(6.5 \pm 3.2) \times 10^{-3}$ & - & - & $(2.7 \pm 4.6) \times 10^{-4}$ & - \\
\hline $\mathrm{C}_{10} \mathrm{H}_{18}$ isomer & $\mathrm{C}_{10} \mathrm{H}_{18}$ & 1369.57 & 1.153 & - & - & - & - & - & $(4.8 \pm 2.4) \times 10^{-3}$ \\
\hline $\mathrm{C}_{10} \mathrm{H}_{18}$ isomer & $\mathrm{C}_{10} \mathrm{H}_{18}$ & 1374.57 & 1.166 & $(1.3 \pm 0.6) \times 10^{-3}$ & $(2.5 \pm 1.2) \times 10^{-3}$ & - & - & - & $0.014 \pm 0.007$ \\
\hline $\mathrm{C}_{10} \mathrm{H}_{18}$ isomer & $\mathrm{C}_{10} \mathrm{H}_{18}$ & 1384.56 & 1.162 & $(3.1 \pm 1.8) \times 10^{-3}$ & $(7.9 \pm 4.0) \times 10^{-3}$ & - & - & $(2.5 \pm 4.6) \times 10^{-4}$ & - \\
\hline $\mathrm{C}_{10} \mathrm{H}_{18}$ isomer & $\mathrm{C}_{10} \mathrm{H}_{18}$ & 1394.56 & 1.17 & $(2.4 \pm 1.2) \times 10^{-3}$ & $(2.7 \pm 1.4) \times 10^{-3}$ & - & - & - & - \\
\hline $\mathrm{C}_{10} \mathrm{H}_{18}$ isomer & $\mathrm{C}_{10} \mathrm{H}_{18}$ & 1419.55 & 1.179 & - & $(2.7 \pm 2.1) \times 10^{-3}$ & - & - & - & - \\
\hline $\mathrm{C}_{10} \mathrm{H}_{18}$ isomer & $\mathrm{C}_{10} \mathrm{H}_{18}$ & 1434.55 & 1.175 & - & $(2.3 \pm 1.1) \times 10^{-3}$ & - & - & - & - \\
\hline $\mathrm{C}_{10} \mathrm{H}_{18}$ isomer & $\mathrm{C}_{10} \mathrm{H}_{18}$ & 1454.54 & 1.197 & $(2.2 \pm 1.1) \times 10^{-3}$ & $(3.4 \pm 1.7) \times 10^{-3}$ & - & - & - & $0.010 \pm 0.006$ \\
\hline $\mathrm{C}_{10} \mathrm{H}_{18}$ isomer & $\mathrm{C}_{10} \mathrm{H}_{18}$ & 1459.54 & 1.21 & $(9.3 \pm 4.7) \times 10^{-3}$ & $0.016 \pm 0.008$ & - & - & $(7.4 \pm 4.6) \times 10^{-4}$ & - \\
\hline $\mathrm{C}_{10} \mathrm{H}_{18}$ isomer & $\mathrm{C}_{10} \mathrm{H}_{18}$ & 1509.52 & 1.17 & - & $(2.1 \pm 1.0) \times 10^{-3}$ & - & - & - & $(5.4 \pm 2.7) \times 10^{-3}$ \\
\hline $\mathrm{C}_{10} \mathrm{H}_{18}$ isomer & $\mathrm{C}_{10} \mathrm{H}_{18}$ & 1539.51 & 1.21 & - & - & - & - & - & $(5.6 \pm 2.8) \times 10^{-3}$ \\
\hline 1,10-Undecadiene & $\mathrm{C}_{11} \mathrm{H}_{20}$ & 1599.49 & 1.162 & $(3.2 \pm 1.8) \times 10^{-3}$ & $(6.2 \pm 3.1) \times 10^{-3}$ & - & - & $(3.5 \pm 4.6) \times 10^{-4}$ & $0.014 \pm 0.007$ \\
\hline $\mathrm{C}_{11} \mathrm{H}_{20}$ isomer & $\mathrm{C}_{11} \mathrm{H}_{20}$ & 1624.49 & 1.17 & - & $(2.4 \pm 1.2) \times 10^{-3}$ & - & - & - & $(5.9 \pm 2.9) \times 10^{-3}$ \\
\hline $\mathrm{C}_{11} \mathrm{H}_{20}$ isomer & $\mathrm{C}_{11} \mathrm{H}_{20}$ & 1639.48 & 1.157 & $(1.5 \pm 0.8) \times 10^{-3}$ & - & - & - & - & - \\
\hline $\mathrm{C}_{11} \mathrm{H}_{20}$ isomer & $\mathrm{C}_{11} \mathrm{H}_{20}$ & 1704.46 & 1.206 & $(2.2 \pm 1.8) \times 10^{-3}$ & $(3.0 \pm 1.5) \times 10^{-3}$ & - & - & - & $(7.1 \pm 3.6) \times 10^{-3}$ \\
\hline $\mathrm{C}_{11} \mathrm{H}_{20}$ isomer & $\mathrm{C}_{11} \mathrm{H}_{20}$ & 1719.46 & 1.197 & $(2.9 \pm 1.9) \times 10^{-3}$ & $(2.5 \pm 1.2) \times 10^{-3}$ & - & - & - & - \\
\hline 1,11-Dodecadiene & $\mathrm{C}_{12} \mathrm{H}_{22}$ & 1834.42 & 1.17 & $(8.5 \pm 4.3) \times 10^{-3}$ & $0.010 \pm 0.005$ & - & - & - & $0.014 \pm 0.007$ \\
\hline 1,12-Tridecadiene & $\mathrm{C}_{13} \mathrm{H}_{24}$ & 2059.35 & 1.175 & $(2.9 \pm 1.9) \times 10^{-3}$ & $(3.5 \pm 2.3) \times 10^{-3}$ & - & - & - & $0.013 \pm 0.007$ \\
\hline $\mathrm{C}_{14} \mathrm{H}_{26}$ isomer & $\mathrm{C}_{14} \mathrm{H}_{26}$ & 2234.29 & 1.285 & - & - & - & - & - & $0.022 \pm 0.011$ \\
\hline \multicolumn{10}{|l|}{$3 \mathrm{DBE}$} \\
\hline 1-Buten-3-yne, 2-methyl- & $\mathrm{C}_{5} \mathrm{H}_{6}$ & 174.95 & 1.144 & $(2.2 \pm 1.2) \times 10^{-3}$ & $(2.4 \pm 1.4) \times 10^{-3}$ & - & - & $(2.0 \pm 3.1) \times 10^{-4}$ & - \\
\hline 4-Penten-1-yne & $\mathrm{C}_{5} \mathrm{H}_{6}$ & 209.939 & 1.307 & $(9.2 \pm 12.0) \times 10^{-4}$ & $(3.7 \pm 1.8) \times 10^{-3}$ & $(3.0 \pm 1.5) \times 10^{-4}$ & - & $(3.6 \pm 3.1) \times 10^{-4}$ & - \\
\hline 1,3-Cyclopentadiene & $\mathrm{C}_{5} \mathrm{H}_{6}$ & 219.936 & 1.126 & $0.14 \pm 0.07$ & $0.18 \pm 0.09$ & $0.032 \pm 0.016$ & $(9.4 \pm 4.7) \times 10^{-3}$ & $0.036 \pm 0.018$ & $0.063 \pm 0.032$ \\
\hline 3-Penten-1-yne, (E)- & $\mathrm{C}_{5} \mathrm{H}_{6}$ & 224.934 & 1.417 & $(1.4 \pm 0.7) \times 10^{-3}$ & - & - & - & $(1.4 \pm 3.1) \times 10^{-4}$ & - \\
\hline 1-Penten-3-yne & $\mathrm{C}_{5} \mathrm{H}_{6}$ & 229.933 & 1.153 & $(3.3 \pm 1.6) \times 10^{-3}$ & $(3.4 \pm 1.7) \times 10^{-3}$ & $(6.0 \pm 3.0) \times 10^{-4}$ & - & $(9.1 \pm 4.6) \times 10^{-4}$ & - \\
\hline 3-Penten-1-yne, (Z)- & $\mathrm{C}_{5} \mathrm{H}_{6}$ & 269.92 & 1.373 & $(7.4 \pm 3.7) \times 10^{-3}$ & $(6.5 \pm 3.3) \times 10^{-3}$ & $(1.4 \pm 0.7) \times 10^{-3}$ & - & $(2.9 \pm 1.4) \times 10^{-3}$ & - \\
\hline 1-Hexen-3-yne & $\mathrm{C}_{6} \mathrm{H}_{8}$ & 309.907 & 1.219 & $(2.7 \pm 1.3) \times 10^{-3}$ & $(6.3 \pm 3.2) \times 10^{-3}$ & - & - & $(8.1 \pm 4.0) \times 10^{-4}$ & - \\
\hline 1,3-Cyclopentadiene, 1-methyl- & $\mathrm{C}_{6} \mathrm{H}_{8}$ & 394.88 & 1.267 & $0.061 \pm 0.031$ & $0.091 \pm 0.045$ & $(5.0 \pm 2.5) \times 10^{-3}$ & $(3.6 \pm 1.8) \times 10^{-3}$ & $0.013 \pm 0.007$ & $0.047 \pm 0.023$ \\
\hline 1,3-Cyclopentadiene, 5-methyl- & $\mathrm{C}_{6} \mathrm{H}_{8}$ & 404.877 & 1.289 & $0.054 \pm 0.027$ & $0.078 \pm 0.039$ & $(4.2 \pm 2.1) \times 10^{-3}$ & $(2.9 \pm 1.5) \times 10^{-3}$ & $0.011 \pm 0.006$ & $0.039 \pm 0.02$ \\
\hline 1,3-Cyclohexadiene & $\mathrm{C}_{6} \mathrm{H}_{8}$ & 464.858 & 1.316 & $0.044 \pm 0.009$ & $0.069 \pm 0.014$ & $(2.0 \pm 0.4) \times 10^{-3}$ & $(2.2 \pm 0.5) \times 10^{-3}$ & $(6.7 \pm 1.3) \times 10^{-3}$ & $0.022 \pm 0.004$ \\
\hline 2-Hexene-4-yne & $\mathrm{C}_{6} \mathrm{H}_{8}$ & 529.837 & 1.514 & - & - & - & - & $(3.3 \pm 2.5) \times 10^{-4}$ & - \\
\hline 1,4-Cyclohexadiene & $\mathrm{C}_{6} \mathrm{H}_{8}$ & 559.827 & 1.39 & - & $(1.6 \pm 0.4) \times 10^{-3}$ & - & - & - & - \\
\hline $\mathrm{C}_{7} \mathrm{H}_{10}$ isomer & $\mathrm{C}_{7} \mathrm{H}_{10}$ & 554.829 & 1.21 & $(3.6 \pm 1.8) \times 10^{-3}$ & $(2.7 \pm 1.3) \times 10^{-3}$ & - & - & - & - \\
\hline $\mathrm{C}_{7} \mathrm{H}_{10}$ isomer & $\mathrm{C}_{7} \mathrm{H}_{10}$ & 589.818 & 1.25 & $(1.0 \pm 0.9) \times 10^{-3}$ & $(1.2 \pm 1.1) \times 10^{-3}$ & - & - & - & - \\
\hline $\mathrm{C}_{7} \mathrm{H}_{10}$ isomer & $\mathrm{C}_{7} \mathrm{H}_{10}$ & 604.813 & 1.267 & $(5.0 \pm 9.4) \times 10^{-4}$ & $(2.2 \pm 1.1) \times 10^{-3}$ & - & - & $(1.4 \pm 2.5) \times 10^{-4}$ & - \\
\hline $\mathrm{C}_{7} \mathrm{H}_{10}$ isomer & $\mathrm{C}_{7} \mathrm{H}_{10}$ & 624.806 & 1.276 & $(3.5 \pm 1.7) \times 10^{-3}$ & $(5.4 \pm 2.7) \times 10^{-3}$ & - & - & $(4.2 \pm 2.5) \times 10^{-4}$ & $(4.4 \pm 2.2) \times 10^{-3}$ \\
\hline $\mathrm{C}_{7} \mathrm{H}_{10}$ isomer & $\mathrm{C}_{7} \mathrm{H}_{10}$ & 669.792 & 1.302 & $0.012 \pm 0.006$ & $0.019 \pm 0.01$ & - & $(9.2 \pm 5.0) \times 10^{-4}$ & $(9.9 \pm 4.9) \times 10^{-4}$ & $0.020 \pm 0.01$ \\
\hline $\mathrm{C}_{7} \mathrm{H}_{10}$ isomer & $\mathrm{C}_{7} \mathrm{H}_{10}$ & 679.789 & 1.316 & $(4.8 \pm 2.4) \times 10^{-3}$ & $(3.0 \pm 1.5) \times 10^{-3}$ & - & - & $(5.1 \pm 3.3) \times 10^{-3}-$ & \\
\hline $\mathrm{C}_{7} \mathrm{H}_{10}$ isomer & $\mathrm{C}_{7} \mathrm{H}_{10}$ & 679.789 & 1.324 & - & $(5.0 \pm 2.5) \times 10^{-3}$ & - & - & $(5.3 \pm 2.7) \times 10^{-4}$ & - \\
\hline $\mathrm{C}_{7} \mathrm{H}_{10}$ isomer & $\mathrm{C}_{7} \mathrm{H}_{10}$ & 689.786 & 1.32 & $0.031 \pm 0.016$ & $0.013 \pm 0.006$ & - & $(2.8 \pm 5.0) \times 10^{-4}$ & $(6.0 \pm 3.0) \times 10^{-4}$ & $0.013 \pm 0.007$ \\
\hline $\mathrm{C}_{7} \mathrm{H}_{10}$ isomer & $\mathrm{C}_{7} \mathrm{H}_{10}$ & 714.778 & 1.342 & $0.026 \pm 0.013$ & $0.022 \pm 0.011$ & - & $(2.7 \pm 5.0) \times 10^{-4}$ & $(7.0 \pm 3.5) \times 10^{-4}$ & $0.015 \pm 0.007$ \\
\hline $\mathrm{C}_{7} \mathrm{H}_{10}$ isomer & $\mathrm{C}_{7} \mathrm{H}_{10}$ & 734.771 & 1.346 & $(7.7 \pm 3.8) \times 10^{-3}$ & $0.018 \pm 0.009$ & - & (2.) & $(2.4 \pm 2.5) \times 10^{-4}$ & $(7.4 \pm 3.7) \times 10^{-3}$ \\
\hline $\mathrm{C}_{7} \mathrm{H}_{10}$ isomer & $\mathrm{C}_{7} \mathrm{H}_{10}$ & 754.765 & 1.355 & $(5.7 \pm 2.9) \times 10^{-3}$ & $(6.1 \pm 3.1) \times 10^{-3}$ & - & - & $(7.2 \pm 3.6) \times 10^{-4}$ & - \\
\hline $\mathrm{C}_{7} \mathrm{H}_{10}$ isomer & $\mathrm{C}_{7} \mathrm{H}_{10}$ & 764.762 & 1.36 & $(1.8 \pm 0.9) \times 10^{-3}$ & $(5.9 \pm 2.9) \times 10^{-3}$ & - & - & - & - \\
\hline $\mathrm{C}_{7} \mathrm{H}_{10}$ isomer & $\mathrm{C}_{7} \mathrm{H}_{10}$ & 774.758 & 1.364 & $(7.3 \pm 3.7) \times 10^{-3}$ & $0.015 \pm 0.007$ & - & - & $(1.3 \pm 0.6) \times 10^{-3}$ & $(7.8 \pm 3.9) \times 10^{-3}$ \\
\hline $\mathrm{C}_{7} \mathrm{H}_{10}$ isomer & $\mathrm{C}_{7} \mathrm{H}_{10}$ & 834.739 & 1.404 & $(2.6 \pm 1.3) \times 10^{-3}$ & $(5.2 \pm 2.6) \times 10^{-3}$ & - & - & - & $(4.4 \pm 2.2) \times 10^{-3}$ \\
\hline $\mathrm{C}_{8} \mathrm{H}_{12}$ isomer & $\mathrm{C}_{8} \mathrm{H}_{12}$ & 874.726 & 1.276 & $(2.1 \pm 1.0) \times 10^{-3}$ & $(5.8 \pm 2.9) \times 10^{-3}$ & - & - & - & $(3.7 \pm 1.9) \times 10^{-3}$ \\
\hline $\mathrm{C}_{8} \mathrm{H}_{12}$ isomer & $\mathrm{C}_{8} \mathrm{H}_{12}$ & 889.722 & 1.28 & $(1.6 \pm 0.8) \times 10^{-3}$ & $(1.3 \pm 0.7) \times 10^{-3}$ & - & - & - & 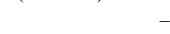 \\
\hline $\mathrm{C}_{8} \mathrm{H}_{12}$ isomer & $\mathrm{C}_{8} \mathrm{H}_{12}$ & 919.712 & 1.298 & - & $(1.4 \pm 0.7) \times 10^{-3}$ & - & - & - & - \\
\hline
\end{tabular}


Table A1. Continued.

\begin{tabular}{|c|c|c|c|c|c|c|c|c|c|}
\hline $\mathrm{C}_{8} \mathrm{H}_{12}$ isomer & $\mathrm{C}_{8} \mathrm{H}_{12}$ & 929.709 & 1.302 & $(1.2 \pm 0.9) \times 10^{-3}$ & $(2.2 \pm 1.1) \times 10^{-3}$ & - & - & - & - \\
\hline $\mathrm{C}_{8} \mathrm{H}_{12}$ isomer & $\mathrm{C}_{8} \mathrm{H}_{12}$ & 939.706 & 1.324 & $(2.2 \pm 1.1) \times 10^{-3}$ & $(3.9 \pm 1.9) \times 10^{-3}$ & - & - & - & - \\
\hline $\mathrm{C}_{8} \mathrm{H}_{12}$ isomer & $\mathrm{C}_{8} \mathrm{H}_{12}$ & 959.699 & 1.32 & - & $(2.3 \pm 1.1) \times 10^{-3}$ & - & - & - & - \\
\hline $\mathrm{C}_{8} \mathrm{H}_{12}$ isomer & $\mathrm{C}_{8} \mathrm{H}_{12}$ & 979.693 & 1.311 & $(3.6 \pm 1.8) \times 10^{-3}$ & $(1.3 \pm 1.1) \times 10^{-3}$ & - & - & - & $(3.0 \pm 3.2) \times 10^{-3}$ \\
\hline $\mathrm{C}_{8} \mathrm{H}_{12}$ isomer & $\mathrm{C}_{8} \mathrm{H}_{12}$ & 979.693 & 1.324 & _- & $(1.5 \pm 1.1) \times 10^{-3}$ & - & - & _- & - \\
\hline $\mathrm{C}_{8} \mathrm{H}_{12}$ isomer & $\mathrm{C}_{8} \mathrm{H}_{12}$ & 989.69 & 1.263 & $(1.4 \pm 0.7) \times 10^{-3}$ & $(1.8 \pm 0.9) \times 10^{-3}$ & - & - & - & - \\
\hline $\mathrm{C}_{8} \mathrm{H}_{12}$ isomer & $\mathrm{C}_{8} \mathrm{H}_{12}$ & 994.688 & 1.338 & $(1.3 \pm 0.7) \times 10^{-3}$ & $(6.1 \pm 3.1) \times 10^{-3}$ & - & - & - & $(4.3 \pm 2.2) \times 10^{-3}$ \\
\hline $\mathrm{C}_{8} \mathrm{H}_{12}$ isomer & $\mathrm{C}_{8} \mathrm{H}_{12}$ & 1009.68 & 1.351 & - & $(1.3 \pm 1.1) \times 10^{-3}$ & - & - & - & - \\
\hline $\mathrm{C}_{8} \mathrm{H}_{12}$ isomer & $\mathrm{C}_{8} \mathrm{H}_{12}$ & 1024.68 & 1.36 & $(1.3 \pm 0.6) \times 10^{-3}$ & $(2.9 \pm 1.4) \times 10^{-3}$ & - & - & - & - \\
\hline $\mathrm{C}_{8} \mathrm{H}_{12}$ isomer & $\mathrm{C}_{8} \mathrm{H}_{12}$ & 1034.68 & 1.355 & $(5.6 \pm 2.8) \times 10^{-3}$ & $(2.9 \pm 1.4) \times 10^{-3}$ & - & - & - & $(4.3 \pm 2.1) \times 10^{-3}$ \\
\hline $\mathrm{C}_{8} \mathrm{H}_{12}$ isomer & $\mathrm{C}_{8} \mathrm{H}_{12}$ & 1059.67 & 1.404 & $(2.5 \pm 1.2) \times 10^{-3}$ & $0.010 \pm 0.005$ & - & - & - & - \\
\hline $\mathrm{C}_{8} \mathrm{H}_{12}$ isomer & $\mathrm{C}_{8} \mathrm{H}_{12}$ & 1079.66 & 1.395 & - & $(4.2 \pm 2.1) \times 10^{-3}$ & - & - & - & - \\
\hline $\mathrm{C}_{8} \mathrm{H}_{12}$ isomer & $\mathrm{C}_{8} \mathrm{H}_{12}$ & 1089.66 & 1.377 & $(3.3 \pm 1.6) \times 10^{-3}$ & $(3.1 \pm 1.6) \times 10^{-3}$ & - & - & - & $(3.9 \pm 2.0) \times 10^{-3}$ \\
\hline $\mathrm{C}_{8} \mathrm{H}_{12}$ isomer & $\mathrm{C}_{8} \mathrm{H}_{12}$ & 1109.65 & 1.412 & $(1.6 \pm 0.9) \times 10^{-3}$ & - & - & - & - & - \\
\hline $\mathrm{C}_{8} \mathrm{H}_{12}$ isomer & $\mathrm{C}_{8} \mathrm{H}_{12}$ & 1139.64 & 1.399 & - & $(2.4 \pm 1.2) \times 10^{-3}$ & - & - & - & $(3.9 \pm 1.9) \times 10^{-3}$ \\
\hline $\mathrm{C}_{8} \mathrm{H}_{12}$ isomer & $\mathrm{C}_{8} \mathrm{H}_{12}$ & 1144.64 & 1.452 & - & $(2.5 \pm 1.3) \times 10^{-3}$ & - & - & - & - \\
\hline $\mathrm{C}_{9} \mathrm{H}_{14}$ isomer & $\mathrm{C}_{9} \mathrm{H}_{14}$ & 939.706 & 1.192 & $(9.6 \pm 4.8) \times 10^{-4}$ & $(1.5 \pm 0.8) \times 10^{-3}$ & - & - & - & $(9.7 \pm 4.9) \times 10^{-3}$ \\
\hline $\mathrm{C}_{9} \mathrm{H}_{14}$ isomer & $\mathrm{C}_{9} \mathrm{H}_{14}$ & 954.701 & 1.188 & - & - & - & - & - & $(6.6 \pm 3.3) \times 10^{-3}$ \\
\hline $\mathrm{C}_{9} \mathrm{H}_{14}$ isomer & $\mathrm{C}_{9} \mathrm{H}_{14}$ & 1029.68 & 1.258 & - & - & - & - & - & $(3.2 \pm 1.6) \times 10^{-3}$ \\
\hline $\mathrm{C}_{9} \mathrm{H}_{14}$ isomer & $\mathrm{C}_{9} \mathrm{H}_{14}$ & 1069.66 & 1.113 & - & - & - & - & - & $(9.6 \pm 4.8) \times 10^{-3}$ \\
\hline $\mathrm{C}_{9} \mathrm{H}_{14}$ isomer & $\mathrm{C}_{9} \mathrm{H}_{14}$ & 1089.66 & 1.228 & $(9.3 \pm 10.0) \times 10^{-4}$ & $(6.7 \pm 12.1) \times 10^{-4}$ & - & - & $(2.8 \pm 2.6) \times 10^{-4}$ & - \\
\hline $\mathrm{C}_{9} \mathrm{H}_{14}$ isomer & $\mathrm{C}_{9} \mathrm{H}_{14}$ & 1099.65 & 1.254 & - & $(8.1 \pm 12.1) \times 10^{-4}$ & - & - & - & - \\
\hline $\mathrm{C}_{9} \mathrm{H}_{14}$ isomer & $\mathrm{C}_{9} \mathrm{H}_{14}$ & 1124.65 & 1.245 & $0.010 \pm 0.005$ & $(3.2 \pm 1.6) \times 10^{-3}$ & - & - & - & - \\
\hline $\mathrm{C}_{9} \mathrm{H}_{14}$ isomer & $\mathrm{C}_{9} \mathrm{H}_{14}$ & 1154.64 & 1.236 & - & $(2.0 \pm 1.2) \times 10^{-3}$ & - & - & - & - \\
\hline $\mathrm{C}_{9} \mathrm{H}_{14}$ isomer & $\mathrm{C}_{9} \mathrm{H}_{14}$ & 1194.62 & 1.302 & - & $(1.3 \pm 1.2) \times 10^{-3}$ & - & - & - & - \\
\hline $\mathrm{C}_{9} \mathrm{H}_{14}$ isomer & $\mathrm{C}_{9} \mathrm{H}_{14}$ & 1214.62 & 1.298 & - & $(2.3 \pm 1.2) \times 10^{-3}$ & - & - & - & - \\
\hline $\mathrm{C}_{9} \mathrm{H}_{14}$ isomer & $\mathrm{C}_{9} \mathrm{H}_{14}$ & 1229.61 & 1.32 & - & $(6.7 \pm 12.1) \times 10^{-4}$ & - & - & - & - \\
\hline $\mathrm{C}_{9} \mathrm{H}_{14}$ isomer & $\mathrm{C}_{9} \mathrm{H}_{14}$ & 1259.6 & 1.355 & - & $(2.3 \pm 1.2) \times 10^{-3}$ & - & - & - & - \\
\hline $\mathrm{C}_{11} \mathrm{H}_{18}$ isomer & $\mathrm{C}_{11} \mathrm{H}_{18}$ & 1794.43 & 1.342 & $(2.9 \pm 1.9) \times 10^{-3}$ & $(3.9 \pm 2.3) \times 10^{-3}$ & - & - & - & - \\
\hline \multicolumn{10}{|l|}{ Other } \\
\hline 1,5-Hexadien-3-yne & $\mathrm{C}_{6} \mathrm{H}_{6}$ & 404.877 & 1.659 & $(7.8 \pm 3.9) \times 10^{-3}$ & $(8.9 \pm 4.5) \times 10^{-3}$ & $(5.1 \pm 8.7) \times 10^{-4}$ & $(5.5 \pm 2.7) \times 10^{-4}$ & $(2.3 \pm 1.2) \times 10^{-3}$ & $(3.2 \pm 1.6) \times 10^{-3}$ \\
\hline 1,5-Hexadiyne & $\mathrm{C}_{6} \mathrm{H}_{6}$ & 439.866 & 1.69 & $(4.9 \pm 2.5) \times 10^{-4}$ & $(8.6 \pm 4.3) \times 10^{-4}$ & - & - & - & - \\
\hline $\mathrm{C}_{7} \mathrm{H}_{8}$ isomer & $\mathrm{C}_{7} \mathrm{H}_{8}$ & 679.789 & 1.632 & $(3.5 \pm 1.8) \times 10^{-3}$ & $(2.6 \pm 1.3) \times 10^{-3}$ & - & - & $(8.7 \pm 4.3) \times 10^{-4}$ & $(2.1 \pm 1.1) \times 10^{-3}$ \\
\hline $\mathrm{C}_{7} \mathrm{H}_{8}$ isomer & $\mathrm{C}_{7} \mathrm{H}_{8}$ & 714.778 & 1.672 & $(4.4 \pm 2.2) \times 10^{-3}$ & $(2.0 \pm 1.0) \times 10^{-3}$ & - & - & $(5.1 \pm 2.6) \times 10^{-4}$ & - \\
\hline $\mathrm{C}_{7} \mathrm{H}_{8}$ isomer & $\mathrm{C}_{7} \mathrm{H}_{8}$ & 859.731 & 1.936 & - & $(1.1 \pm 0.5) \times 10^{-3}$ & - & - & - & - \\
\hline 1,3,5-Cycloheptatriene & $\mathrm{C}_{7} \mathrm{H}_{8}$ & 864.73 & 1.918 & $(1.1 \pm 0.5) \times 10^{-3}$ & - & $(2.3 \pm 1.2) \times 10^{-4}$ & - & $(7.5 \pm 3.8) \times 10^{-4}$ & - \\
\hline $\mathrm{C}_{8} \mathrm{H}_{8}$ isomer & $\mathrm{C}_{8} \mathrm{H}_{8}$ & 1219.62 & 1.888 & $(1.9 \pm 0.9) \times 10^{-3}$ & $(1.6 \pm 0.8) \times 10^{-3}$ & $(3.9 \pm 4.0) \times 10^{-4}$ & - & $(2.3 \pm 2.9) \times 10^{-4}$ & - \\
\hline $\mathrm{C}_{8} \mathrm{H}_{10}$ isomer & $\mathrm{C}_{8} \mathrm{H}_{10}$ & 1039.67 & 1.641 & $(2.3 \pm 1.1) \times 10^{-3}$ & - & - & - & - & - \\
\hline $\mathrm{C}_{8} \mathrm{H}_{10}$ isomer & $\mathrm{C}_{8} \mathrm{H}_{10}$ & 1044.67 & 1.602 & - & $(1.7 \pm 0.9) \times 10^{-3}$ & - & - & - & - \\
\hline $\mathrm{C}_{8} \mathrm{H}_{10}$ isomer & $\mathrm{C}_{8} \mathrm{H}_{10}$ & 1074.66 & 1.65 & $(1.2 \pm 0.6) \times 10^{-3}$ & $(1.9 \pm 1.0) \times 10^{-3}$ & - & - & - & - \\
\hline $\mathrm{C}_{8} \mathrm{H}_{10}$ isomer & $\mathrm{C}_{8} \mathrm{H}_{10}$ & 1144.64 & 1.786 & - & $(1.8 \pm 0.9) \times 10^{-3}$ & - & - & - & - \\
\hline $\mathrm{C}_{8} \mathrm{H}_{10}$ isomer & $\mathrm{C}_{8} \mathrm{H}_{10}$ & 1154.64 & 1.76 & - & - & - & - & $(5.6 \pm 2.8) \times 10^{-4}$ & - \\
\hline $\mathrm{C}_{9} \mathrm{H}_{12}$ isomer & $\mathrm{C}_{9} \mathrm{H}_{12}$ & 1014.68 & 1.267 & $(2.4 \pm 1.2) \times 10^{-3}$ & - & - & - & - & - \\
\hline $\mathrm{C}_{10} \mathrm{H}_{14}$ isomer & $\mathrm{C}_{10} \mathrm{H}_{14}$ & 1169.63 & 1.267 & $(5.1 \pm 2.5) \times 10^{-3}$ & - & - & - & - & - \\
\hline $\mathrm{C}_{10} \mathrm{H}_{14}$ isomer & $\mathrm{C}_{10} \mathrm{H}_{14}$ & 1304.59 & 1.28 & $(1.3 \pm 0.6) \times 10^{-3}$ & - & - & - & - & - \\
\hline $\mathrm{C}_{10} \mathrm{H}_{14}$ isomer & $\mathrm{C}_{10} \mathrm{H}_{14}$ & 1334.58 & 1.412 & $(1.9 \pm 0.9) \times 10^{-3}$ & $(4.4 \pm 2.2) \times 10^{-3}$ & - & - & - & - \\
\hline $\mathrm{C}_{10} \mathrm{H}_{14}$ isomer & $\mathrm{C}_{10} \mathrm{H}_{14}$ & 1409.56 & 1.434 & $(2.1 \pm 1.0) \times 10^{-3}$ & $(6.6 \pm 3.3) \times 10^{-3}$ & - & - & - & - \\
\hline $\mathrm{C}_{10} \mathrm{H}_{14}$ isomer & $\mathrm{C}_{10} \mathrm{H}_{14}$ & 1464.54 & 1.487 & _- & $(7.3 \pm 3.6) \times 10^{-3}$ & _- & - & _- & _- \\
\hline $\mathrm{C}_{11} \mathrm{H}_{16}$ isomer & $\mathrm{C}_{11} \mathrm{H}_{16}$ & 1629.48 & 1.465 & - & $(1.6 \pm 0.8) \times 10^{-3}$ & - & - & - & - \\
\hline \multicolumn{10}{|l|}{ Terpenoids } \\
\hline \multicolumn{10}{|l|}{ Other } \\
\hline Isoprene & $\mathrm{C}_{5} \mathrm{H}_{8}$ & 189.946 & 0.994 & $0.28 \pm 0.06$ & $0.40 \pm 0.08$ & $0.030 \pm 0.006$ & $0.012 \pm 0.002$ & $0.088 \pm 0.018$ & $0.31 \pm 0.06$ \\
\hline Santene & $\mathrm{C}_{9} \mathrm{H}_{14}$ & 1069.66 & 1.157 & $0.12 \pm 0.06$ & - & - & - & - & - \\
\hline Bornyl acetate & $\mathrm{C}_{12} \mathrm{H}_{20} \mathrm{O}_{2}$ & 2094.34 & 1.628 & $0.040 \pm 0.02$ & - & - & - & - & - \\
\hline \multicolumn{10}{|l|}{ Monoterpenes } \\
\hline $\mathrm{C}_{10} \mathrm{H}_{16}$ isomer & $\mathrm{C}_{10} \mathrm{H}_{16}$ & 1069.66 & 1.091 & - & $(1.2 \pm 0.6) \times 10^{-3}$ & - & - & - & - \\
\hline Bornylene & $\mathrm{C}_{10} \mathrm{H}_{16}$ & 1129.64 & 1.144 & $(8.7 \pm 4.3) \times 10^{-3}$ & - & - & - & - & - \\
\hline $\mathrm{C}_{10} \mathrm{H}_{16}$ isomer & $\mathrm{C}_{10} \mathrm{H}_{16}$ & 1159.64 & 1.228 & - & $(2.2 \pm 1.1) \times 10^{-3}$ & - & - & - & - \\
\hline$\gamma$-Pyronene & $\mathrm{C}_{10} \mathrm{H}_{16}$ & 1174.63 & 1.197 & $0.017 \pm 0.008$ & $(8.8 \pm 4.4) \times 10^{-3}$ & - & - & $(5.0 \pm 2.5) \times 10^{-4}$ & - \\
\hline Tricyclene & $\mathrm{C}_{10} \mathrm{H}_{16}$ & 1189.63 & 1.153 & $0.20 \pm 0.1$ & - & - & - & - & - \\
\hline$\alpha$-Thujene & $\mathrm{C}_{10} \mathrm{H}_{16}$ & 1194.62 & 1.157 & - & $(8.9 \pm 4.5) \times 10^{-3}$ & - & - & - & - \\
\hline$\alpha$-Pinene & $\mathrm{C}_{10} \mathrm{H}_{16}$ & 1219.62 & 1.157 & $0.17 \pm 0.03$ & $0.082 \pm 0.016$ & - & - & $(8.6 \pm 7.3) \times 10^{-4}$ & - \\
\hline $\mathrm{C}_{10} \mathrm{H}_{16}$ isomer & $\mathrm{C}_{10} \mathrm{H}_{16}$ & 1244.61 & 1.192 & $(6.3 \pm 3.2) \times 10^{-3}$ & $(3.1 \pm 1.6) \times 10^{-3}$ & - & - & - & - \\
\hline$\alpha$-Fenchene & $\mathrm{C}_{10} \mathrm{H}_{16}$ & 1254.6 & 1.201 & $(5.0 \pm 2.5) \times 10^{-3}$ & $(8.8 \pm 4.4) \times 10^{-3}$ & - & - & - & - \\
\hline Camphene & $\mathrm{C}_{10} \mathrm{H}_{16}$ & 1264.6 & 1.228 & $0.44 \pm 0.09$ & $0.017 \pm 0.003$ & - & - & - & - \\
\hline $\mathrm{C}_{10} \mathrm{H}_{16}$ isomer & $\mathrm{C}_{10} \mathrm{H}_{16}$ & 1279.6 & 1.232 & $0.018 \pm 0.009$ & $0.011 \pm 0.006$ & - & - & - & - \\
\hline $\mathrm{C}_{10} \mathrm{H}_{16}$ isomer & $\mathrm{C}_{10} \mathrm{H}_{16}$ & 1284.6 & 1.232 & $(1.5 \pm 0.8) \times 10^{-3}$ & - & - & - & - & - \\
\hline $\mathrm{C}_{10} \mathrm{H}_{16}$ isomer & $\mathrm{C}_{10} \mathrm{H}_{16}$ & 1289.59 & 1.245 & $(9.9 \pm 4.9) \times 10^{-3}$ & $0.017 \pm 0.008$ & - & - & $(2.1 \pm 1.0) \times 10^{-3}$ & - \\
\hline $\mathrm{C}_{10} \mathrm{H}_{16}$ isomer & $\mathrm{C}_{10} \mathrm{H}_{16}$ & 1299.59 & 1.236 & $(1.5 \pm 0.8) \times 10^{-3}$ & $(5.4 \pm 2.7) \times 10^{-3}$ & - & - & - & - \\
\hline $\mathrm{C}_{10} \mathrm{H}_{16}$ isomer & $\mathrm{C}_{10} \mathrm{H}_{16}$ & 1309.59 & 1.223 & $(3.7 \pm 1.9) \times 10^{-3}$ & $(1.5 \pm 0.8) \times 10^{-3}$ & - & - & - & - \\
\hline $\mathrm{C}_{10} \mathrm{H}_{16}$ isomer & $\mathrm{C}_{10} \mathrm{H}_{16}$ & 1319.58 & 1.245 & - & $(1.6 \pm 0.8) \times 10^{-3}$ & - & - & - & - \\
\hline Sabinene & $\mathrm{C}_{10} \mathrm{H}_{16}$ & 1329.58 & 1.267 & $0.022 \pm 0.004$ & $(5.2 \pm 1.3) \times 10^{-3}$ & - & - & - & - \\
\hline$\beta$-Pinene & $\mathrm{C}_{10} \mathrm{H}_{16}$ & 1339.58 & 1.254 & $0.089 \pm 0.018$ & $0.23 \pm 0.05$ & - & - & - & - \\
\hline$\beta$-Pyronene & $\mathrm{C}_{10} \mathrm{H}_{16}$ & 1354.57 & 1.28 & $0.018 \pm 0.009$ & - & - & - & - & - \\
\hline$\beta$-Myrcene & $\mathrm{C}_{10} \mathrm{H}_{16}$ & 1364.57 & 1.28 & $0.13 \pm 0.03$ & $0.22 \pm 0.04$ & - & - & - & $(6.8 \pm 3.9) \times 10^{-3}$ \\
\hline Pyronene? & $\mathrm{C}_{10} \mathrm{H}_{16}$ & 1384.56 & 1.276 & - & $(2.7 \pm 1.3) \times 10^{-3}$ & - & - & - & - \\
\hline $\mathrm{C}_{10} \mathrm{H}_{16}$ isomer & $\mathrm{C}_{10} \mathrm{H}_{16}$ & 1394.56 & 1.245 & $(4.0 \pm 2.0) \times 10^{-3}$ & $(4.9 \pm 2.4) \times 10^{-3}$ & - & - & - & - \\
\hline$\alpha$-Phellandrene & $\mathrm{C}_{10} \mathrm{H}_{16}$ & 1414.55 & 1.302 & $0.013 \pm 0.003$ & $0.016 \pm 0.003$ & - & - & - & - \\
\hline 3-Carene & $\mathrm{C}_{10} \mathrm{H}_{16}$ & 1424.55 & 1.267 & $0.14 \pm 0.03$ & $0.18 \pm 0.04$ & - & - & - & - \\
\hline
\end{tabular}


Table A1. Continued.

\begin{tabular}{|c|c|c|c|c|c|c|c|c|c|}
\hline$\alpha$-Terpinene & $\mathrm{C}_{10} \mathrm{H}_{16}$ & 1444.54 & 1.311 & $0.016 \pm 0.003$ & $0.011 \pm 0.002$ & - & - & - & - \\
\hline $\mathrm{C}_{10} \mathrm{H}_{16}$ isomer & $\mathrm{C}_{10} \mathrm{H}_{16}$ & 1459.54 & 1.307 & $(1.8 \pm 0.9) \times 10^{-3}$ & - & - & - & - & - \\
\hline $\mathrm{C}_{10} \mathrm{H}_{16}$ isomer & $\mathrm{C}_{10} \mathrm{H}_{16}$ & 1464.54 & 1.316 & $(2.3 \pm 1.2) \times 10^{-3}$ & $(3.4 \pm 1.7) \times 10^{-3}$ & - & - & - & - \\
\hline Limonene & $\mathrm{C}_{10} \mathrm{H}_{16}$ & 1474.53 & 1.329 & $0.23 \pm 0.05$ & $0.17 \pm 0.03$ & $(1.3 \pm 1.0) \times 10^{-3}$ & $(2.0 \pm 1.5) \times 10^{-3}$ & $0.018 \pm 0.004$ & - \\
\hline (Z)-Ocimene & $\mathrm{C}_{10} \mathrm{H}_{16}$ & 1479.53 & 1.338 & - & $0.038 \pm 0.008$ & (10- & - & - & - \\
\hline$\beta$-Phellandrene & $\mathrm{C}_{10} \mathrm{H}_{16}$ & 1484.53 & 1.36 & $0.047 \pm 0.023$ & $0.024 \pm 0.012$ & - & - & $(8.8 \pm 4.4) \times 10^{-4}$ & - \\
\hline $\mathrm{C}_{10} \mathrm{H}_{16}$ isomer & $\mathrm{C}_{10} \mathrm{H}_{16}$ & 1499.53 & 1.32 & $(2.7 \pm 1.3) \times 10^{-3}$ & $(5.1 \pm 2.6) \times 10^{-3}$ & - & - & - & - \\
\hline (E)-Ocimene & $\mathrm{C}_{10} \mathrm{H}_{16}$ & 1514.52 & 1.355 & $(4.4 \pm 0.9) \times 10^{-3}$ & $(5.4 \pm 1.1) \times 10^{-3}$ & - & - & - & - \\
\hline$\gamma$-Terpinene & $\mathrm{C}_{10} \mathrm{H}_{16}$ & 1544.51 & 1.364 & $(6.0 \pm 1.4) \times 10^{-3}$ & $(7.7 \pm 1.8) \times 10^{-3}$ & - & - & - & - \\
\hline $\mathrm{C}_{10} \mathrm{H}_{16}$ isomer & $\mathrm{C}_{10} \mathrm{H}_{16}$ & 1589.5 & 1.382 & $(2.7 \pm 1.4) \times 10^{-3}$ & $(6.1 \pm 3.0) \times 10^{-3}$ & - & - & - & - \\
\hline Terpinolene & $\mathrm{C}_{10} \mathrm{H}_{16}$ & 1619.49 & 1.39 & $0.038 \pm 0.008$ & $0.035 \pm 0.007$ & - & - & - & - \\
\hline Allo-ocimene or $\alpha$-pyronene & $\mathrm{C}_{10} \mathrm{H}_{16}$ & 1729.45 & 1.443 & $(4.7 \pm 2.4) \times 10^{-3}$ & $(6.4 \pm 3.2) \times 10^{-3}$ & - & - & - & - \\
\hline 1,3-Cyclohexadiene, 5-butyl- & $\mathrm{C}_{10} \mathrm{H}_{16}$ & 1754.44 & 1.333 & $(1.3 \pm 0.6) \times 10^{-3}$ & - & - & - & - & - \\
\hline Allo-ocimene or $\alpha$-pyronene & $\mathrm{C}_{10} \mathrm{H}_{16}$ & 1764.44 & 1.474 & $(1.8 \pm 0.9) \times 10^{-3}$ & $(2.4 \pm 1.2) \times 10^{-3}$ & - & - & - & - \\
\hline \multicolumn{10}{|l|}{ Sesquiterpenes (and related) } \\
\hline$\alpha$-Calacorene & $\mathrm{C}_{15} \mathrm{H}_{20}$ & 2624.17 & 1.822 & - & - & - & - & - & $0.013 \pm 0.006$ \\
\hline Calamenene & $\mathrm{C}_{15} \mathrm{H}_{22}$ & 2579.18 & 1.654 & $(6.8 \pm 3.4) \times 10^{-3}$ & - & - & - & - & $0.018 \pm 0.009$ \\
\hline$\alpha$-Cubebene & $\mathrm{C}_{15} \mathrm{H}_{24}$ & 2229.29 & 1.241 & $(5.1 \pm 2.5) \times 10^{-3}$ & - & - & - & - & - \\
\hline Copaene & $\mathrm{C}_{15} \mathrm{H}_{24}$ & 2294.27 & 1.28 & $(4.9 \pm 2.4) \times 10^{-3}$ & $(4.9 \pm 2.4) \times 10^{-3}$ & - & - & - & - \\
\hline $\mathrm{C}_{15} \mathrm{H}_{24}$ isomer & $\mathrm{C}_{15} \mathrm{H}_{24}$ & 2319.26 & 1.39 & $(8.4 \pm 4.2) \times 10^{-3}$ & - & - & - & - & - \\
\hline Germacrene D & $\mathrm{C}_{15} \mathrm{H}_{24}$ & 2379.24 & 1.36 & $(6.1 \pm 3.0) \times 10^{-3}$ & $0.012 \pm 0.006$ & - & - & - & - \\
\hline$\beta$-Caryophyllene & $\mathrm{C}_{15} \mathrm{H}_{24}$ & 2394.24 & 1.404 & $(7.3 \pm 1.5) \times 10^{-3}$ & - & - & - & - & - \\
\hline $\mathrm{C}_{15} \mathrm{H}_{24}$ isomer & $\mathrm{C}_{15} \mathrm{H}_{24}$ & 2404.24 & 1.373 & $(5.6 \pm 2.8) \times 10^{-3}$ & $0.010 \pm 0.005$ & - & - & - & - \\
\hline $\mathrm{C}_{15} \mathrm{H}_{24}$ isomer & $\mathrm{C}_{15} \mathrm{H}_{24}$ & 2454.22 & 1.47 & - & $(7.3 \pm 3.7) \times 10^{-3}$ & - & - & - & - \\
\hline Cadinene isomer & $\mathrm{C}_{15} \mathrm{H}_{24}$ & 2484.21 & 1.448 & $(9.6 \pm 4.8) \times 10^{-3}$ & $(7.5 \pm 3.7) \times 10^{-3}$ & - & - & - & - \\
\hline Cadinene isomer & $\mathrm{C}_{15} \mathrm{H}_{24}$ & 2529.2 & 1.456 & $(9.9 \pm 5.0) \times 10^{-3}$ & $(5.5 \pm 2.8) \times 10^{-3}$ & - & - & - & - \\
\hline Cadinene isomer & $\mathrm{C}_{15} \mathrm{H}_{24}$ & 2564.19 & 1.492 & $0.028 \pm 0.014$ & $(8.4 \pm 4.2) \times 10^{-3}$ & - & - & - & - \\
\hline Cadinene isomer & $\mathrm{C}_{15} \mathrm{H}_{24}$ & 2604.17 & 1.536 & $(5.0 \pm 2.5) \times 10^{-3}$ & - & - & - & - & - \\
\hline Ledane & $\mathrm{C}_{15} \mathrm{H}_{26}$ & 2414.23 & 1.355 & - & - & - & - & - & $0.019 \pm 0.009$ \\
\hline $\mathrm{C}_{15} \mathrm{H}_{26}$ Isomer & $\mathrm{C}_{15} \mathrm{H}_{26}$ & 2504.2 & 1.373 & - & - & - & - & - & $0.017 \pm 0.009$ \\
\hline Patchulane & $\mathrm{C}_{15} \mathrm{H}_{26}$ & 2549.19 & 1.448 & - & - & - & - & - & $0.023 \pm 0.012$ \\
\hline \multicolumn{10}{|c|}{ Oxygenated aliphatic compounds } \\
\hline \multicolumn{10}{|l|}{ Aldehydes } \\
\hline Acrolein & $\mathrm{C}_{3} \mathrm{H}_{4} \mathrm{O}$ & 169.952 & 1.426 & $0.22 \pm 0.04$ & $0.26 \pm 0.05$ & $0.035 \pm 0.007$ & $0.027 \pm 0.005$ & $0.062 \pm 0.012$ & $0.057 \pm 0.019$ \\
\hline Propanal & $\mathrm{C}_{3} \mathrm{H}_{6} \mathrm{O}$ & 174.95 & 1.241 & $(9.5 \pm 5.1) \times 10^{-3}$ & $0.010 \pm 0.01$ & $(6.8 \pm 3.4) \times 10^{-3}$ & - & $0.013 \pm 0.006$ & $0.039 \pm 0.025$ \\
\hline Methacrolein & $\mathrm{C}_{4} \mathrm{H}_{6} \mathrm{O}$ & 259.923 & 1.571 & $0.073 \pm 0.015$ & $0.10 \pm 0.02$ & $(8.4 \pm 4.2) \times 10^{-3}$ & $(7.7 \pm 1.5) \times 10^{-3}$ & $0.023 \pm 0.005$ & $0.061 \pm 0.012$ \\
\hline 2-Butenal & $\mathrm{C}_{4} \mathrm{H}_{6} \mathrm{O}$ & 419.872 & 2.517 & $0.079 \pm 0.04$ & $0.15 \pm 0.07$ & $(8.4 \pm 4.2) \times 10^{-3}$ & $0.022 \pm 0.011$ & $0.042 \pm 0.021$ & $0.017 \pm 0.013$ \\
\hline Propanal, 2-methyl- & $\mathrm{C}_{4} \mathrm{H}_{8} \mathrm{O}$ & 239.93 & 1.298 & $0.020 \pm 0.01$ & $0.043 \pm 0.021$ & $(1.2 \pm 1.3) \times 10^{-3}$ & - & $0.013 \pm 0.007$ & $0.15 \pm 0.07$ \\
\hline Acetaldehyde, methoxy- & $\mathrm{C}_{3} \mathrm{H}_{6} \mathrm{O}_{2}$ & 279.917 & 2.592 & - & $(2.5 \pm 1.2) \times 10^{-3}$ & - & - & - & - \\
\hline Butanal & $\mathrm{C}_{4} \mathrm{H}_{8} \mathrm{O}$ & 289.914 & 1.558 & $0.015 \pm 0.004$ & $0.031 \pm 0.006$ & - & $(3.6 \pm 2.0) \times 10^{-3}$ & $0.016 \pm 0.003$ & $(6.7 \pm 12.9) \times 10^{-3}$ \\
\hline Pent-2-ynal & $\mathrm{C}_{5} \mathrm{H}_{6} \mathrm{O}$ & 484.851 & 2.512 & $(1.3 \pm 0.6) \times 10^{-3}$ & $(1.8 \pm 0.9) \times 10^{-3}$ & - & ( & $0.010+0.003$ & - \\
\hline 2-Ethylacrolein & $\mathrm{C}_{5} \mathrm{H}_{8} \mathrm{O}$ & 464.858 & 1.756 & $(3.7 \pm 1.8) \times 10^{-3}$ & $(4.4 \pm 2.2) \times 10^{-3}$ & - & - & $(2.6 \pm 1.3) \times 10^{-3}$ & - \\
\hline 4-Pentenal & $\mathrm{C}_{5} \mathrm{H}_{8} \mathrm{O}$ & 499.846 & 2.182 & $(1.7 \pm 0.8) \times 10^{-3}$ & $(3.4 \pm 1.7) \times 10^{-3}$ & - & - & $(8.1 \pm 4.0) \times 10^{-4}$ & - \\
\hline 2-Butenal, 2-methyl- & $\mathrm{C}_{5} \mathrm{H}_{8} \mathrm{O}$ & 669.792 & 2.174 & $(3.9 \pm 1.9) \times 10^{-3}$ & $(8.5 \pm 4.2) \times 10^{-3}$ & - & - & $(2.5 \pm 1.2) \times 10^{-3}$ & $(6.3 \pm 3.2) \times 10^{-3}$ \\
\hline 2-Pentenal, (E)- & $\mathrm{C}_{5} \mathrm{H}_{8} \mathrm{O}$ & 704.781 & 2.345 & - & $(2.9 \pm 1.4) \times 10^{-3}$ & - & - & $(8.8 \pm 4.4) \times 10^{-4}$ & (0.0 \\
\hline 2-Butenal, 3-methyl- & $\mathrm{C}_{5} \mathrm{H}_{8} \mathrm{O}$ & 794.752 & 2.658 & $(1.8 \pm 0.9) \times 10^{-3}$ & $(3.6 \pm 1.8) \times 10^{-3}$ & - & - & $(4.3 \pm 2.2) \times 10^{-4}$ & - \\
\hline Butanal, 3-methyl- & $\mathrm{C}_{5} \mathrm{H}_{10} \mathrm{O}$ & 429.869 & 1.558 & $0.017 \pm 0.009$ & $0.046 \pm 0.023$ & $(8.3 \pm 4.2) \times 10^{-4}$ & $(2.5 \pm 1.2) \times 10^{-3}$ & $(8.1 \pm 4.0) \times 10^{-3}$ & $0.11 \pm 0.06$ \\
\hline Butanal, 2-methyl- & $\mathrm{C}_{5} \mathrm{H}_{10} \mathrm{O}$ & 449.862 & 1.514 & $(5.4 \pm 2.7) \times 10^{-3}$ & $0.022 \pm 0.011$ & $(5.7 \pm 2.8) \times 10^{-4}$ & $(1.2 \pm 0.6) \times 10^{-3}$ & $(5.0 \pm 2.5) \times 10^{-3}$ & $0.071 \pm 0.035$ \\
\hline Pentanal & $\mathrm{C}_{5} \mathrm{H}_{10} \mathrm{O}$ & 529.837 & 1.707 & $0.016 \pm 0.003$ & $0.020 \pm 0.004$ & - & $(1.1 \pm 0.6) \times 10^{-3}$ & - & $0.014 \pm 0.005$ \\
\hline 2,4-Hexadienal, (E,E)- & $\mathrm{C}_{6} \mathrm{H}_{8} \mathrm{O}$ & 1034.68 & 3.045 & - & - & - & - & $(4.2 \pm 2.1) \times 10^{-3}$ & - \\
\hline Hexanal & $\mathrm{C}_{6} \mathrm{H}_{12} \mathrm{O}$ & 829.741 & 1.694 & $(9.9 \pm 2.5) \times 10^{-3}$ & $0.011 \pm 0.003$ & - & - & $(1.5 \pm 0.7) \times 10^{-3}$ & $0.011 \pm 0.007$ \\
\hline Heptanal & $\mathrm{C}_{7} \mathrm{H}_{14} \mathrm{O}$ & 1124.65 & 1.663 & $(7.0 \pm 3.5) \times 10^{-3}$ & $(8.7 \pm 4.3) \times 10^{-3}$ & - & - & - & $0.017 \pm 0.009$ \\
\hline Octanal & $\mathrm{C}_{8} \mathrm{H}_{16} \mathrm{O}$ & 1399.56 & 1.632 & $(2.6 \pm 1.4) \times 10^{-3}$ & - & - & - & - & - \\
\hline Nonanal & $\mathrm{C}_{9} \mathrm{H}_{18} \mathrm{O}$ & 1659.48 & 1.606 & $(3.9 \pm 1.9) \times 10^{-3}$ & - & - & $(2.9 \pm 1.4) \times 10^{-3}$ & - & - \\
\hline Decanal & $\mathrm{C}_{10} \mathrm{H}_{20} \mathrm{O}$ & 1899.4 & 1.584 & - & - & $(1.6 \pm 0.3) \times 10^{-3}$ & - & - & - \\
\hline Dodecanal & $\mathrm{C}_{12} \mathrm{H}_{24} \mathrm{O}$ & 2329.26 & 1.566 & - & - & $(2.0 \pm 1.0) \times 10^{-3}$ & - & - & $(4.8 \pm 3.1) \times 10^{-3}$ \\
\hline \multicolumn{10}{|l|}{ Ketones } \\
\hline Acetone & $\mathrm{C}_{3} \mathrm{H}_{6} \mathrm{O}$ & 174.95 & 1.32 & $0.13 \pm 0.03$ & $0.25 \pm 0.05$ & $0.035 \pm 0.007$ & $0.036 \pm 0.007$ & $0.11 \pm 0.02$ & $0.37 \pm 0.07$ \\
\hline Hydroxyacetone & $\mathrm{C}_{3} \mathrm{H}_{6} \mathrm{O}_{2}$ & 444.864 & 3.846 & $(9.0 \pm 4.5) \times 10^{-3}$ & $0.052 \pm 0.026$ & $0.010 \pm 0.005$ & $(9.7 \pm 4.9) \times 10^{-3}$ & $0.11 \pm 0.06$ & 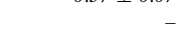 \\
\hline Methyl vinyl ketone & $\mathrm{C}_{4} \mathrm{H}_{6} \mathrm{O}$ & 289.914 & 2.015 & $0.19 \pm 0.04$ & $0.29 \pm 0.06$ & $0.028 \pm 0.006$ & $0.038 \pm 0.008$ & $0.13 \pm 0.03$ & $0.093 \pm 0.019$ \\
\hline 2,3-Butanedione & $\mathrm{C}_{4} \mathrm{H}_{6} \mathrm{O}_{2}$ & 289.914 & 2.253 & $0.098 \pm 0.049$ & $0.18 \pm 0.09$ & $(7.6 \pm 3.8) \times 10^{-3}$ & $0.049 \pm 0.025$ & $0.056 \pm 0.028$ & $0.043 \pm 0.022$ \\
\hline 2-Butanone & $\mathrm{C}_{4} \mathrm{H}_{8} \mathrm{O}$ & 299.91 & 1.685 & $0.038 \pm 0.008$ & $0.12 \pm 0.02$ & $(4.9 \pm 1.0) \times 10^{-3}$ & $0.016 \pm 0.003$ & $0.068 \pm 0.014$ & $0.10 \pm 0.02$ \\
\hline 2-Butanone, 3-hydroxy- & $\mathrm{C}_{4} \mathrm{H}_{8} \mathrm{O}_{2}$ & 564.826 & 1.065 & $0.070+0.000$ & - & (T) & $0.010+0.00$ & $(5.0 \pm 2.5) \times 10^{-3}$ & $-1.0+0.02$ \\
\hline 1-Hydroxy-2-butanone & $\mathrm{C}_{4} \mathrm{H}_{8} \mathrm{O}_{2}$ & 724.774 & 1.514 & - & - & - & - & $(6.5 \pm 3.3) \times 10^{-3}$ & - \\
\hline 3-Cyclopentene-1,2-dione & $\mathrm{C}_{5} \mathrm{H}_{4} \mathrm{O}_{2}$ & 1054.67 & 0.04 & - & - & - & - & $(4.3 \pm 2.1) \times 10^{-3}$ & - \\
\hline 2-Cyclopentene-1,4-dione & $\mathrm{C}_{5} \mathrm{H}_{4} \mathrm{O}_{2}$ & 1089.66 & 2.389 & $0.012 \pm 0.006$ & $0.012 \pm 0.006$ & - & $(4.2 \pm 2.1) \times 10^{-3}$ & $(5.7 \pm 2.8) \times 10^{-3}$ & - \\
\hline 1,4-Pentadien-3-one & $\mathrm{C}_{5} \mathrm{H}_{6} \mathrm{O}$ & 499.846 & 2.592 & - & $(7.5 \pm 3.8) \times 10^{-4}$ & - & - & $(5.1 \pm 2.6) \times 10^{-4}$ & - \\
\hline 3-Cyclopenten-1-one & $\mathrm{C}_{5} \mathrm{H}_{6} \mathrm{O}$ & 694.784 & 3.37 & $(8.9 \pm 4.4) \times 10^{-3}$ & $0.015 \pm 0.007$ & - & $(2.7 \pm 1.3) \times 10^{-3}$ & $(3.9 \pm 2.0) \times 10^{-3}$ & - \\
\hline 2-Cyclopenten-1-one & $\mathrm{C}_{5} \mathrm{H}_{6} \mathrm{O}$ & 929.709 & 4.022 & $0.020 \pm 0.01$ & $0.063 \pm 0.032$ & $(7.0 \pm 3.5) \times 10^{-3}$ & $0.016 \pm 0.008$ & $0.062 \pm 0.031$ & $0.029 \pm 0.015$ \\
\hline 3-Buten-2-one, 3-methyl- & $\mathrm{C}_{5} \mathrm{H}_{8} \mathrm{O}$ & 479.853 & 1.888 & $0.029 \pm 0.015$ & $0.070 \pm 0.035$ & $(2.1 \pm 1.0) \times 10^{-3}$ & $0.011 \pm 0.005$ & $0.023 \pm 0.012$ & $0.035 \pm 0.017$ \\
\hline 4-Penten-2-one & $\mathrm{C}_{5} \mathrm{H}_{8} \mathrm{O}$ & 489.85 & 2.244 & $(2.2 \pm 1.1) \times 10^{-3}$ & $(4.1 \pm 2.0) \times 10^{-3}$ & $(2.3 \pm 1.2) \times 10^{-4}$ & $(4.9 \pm 2.5) \times 10^{-4}$ & $(2.5 \pm 1.2) \times 10^{-3}$ & $(2.1 \pm 1.1) \times 10^{-3}$ \\
\hline 1-Penten-3-one & $\mathrm{C}_{5} \mathrm{H}_{8} \mathrm{O}$ & 509.843 & 2.011 & $(2.5 \pm 1.3) \times 10^{-3}$ & $(3.4 \pm 2.0) \times 10^{-3}$ & $(6.1 \pm 3.1) \times 10^{-4}$ & $(1.2 \pm 0.6) \times 10^{-3}$ & $(8.4 \pm 4.2) \times 10^{-3}$ & $(2.7 \pm 1.3) \times 10^{-3}$ \\
\hline 3-Penten-2-one ( $\mathrm{Z}$ ) & $\mathrm{C}_{5} \mathrm{H}_{8} \mathrm{O}$ & 514.842 & 1.954 & $(2.0 \pm 1.0) \times 10^{-3}$ & $(4.3 \pm 2.1) \times 10^{-3}$ & $(2.4 \pm 1.2) \times 10^{-4}$ & $(5.7 \pm 2.9) \times 10^{-4}$ & $(3.9 \pm 1.9) \times 10^{-3}$ & - \\
\hline $\mathrm{C}_{5} \mathrm{H}_{8} \mathrm{O}$ isomer & $\mathrm{C}_{5} \mathrm{H}_{8} \mathrm{O}$ & 609.811 & 2.244 & - & - & - & - & $(1.1 \pm 0.6) \times 10^{-3}$ & - \\
\hline
\end{tabular}


Table A1. Continued.

\begin{tabular}{|c|c|c|c|c|c|c|c|c|c|}
\hline 3-Penten-2-one, (E)- & $\mathrm{C}_{5} \mathrm{H}_{8} \mathrm{O}$ & 669.792 & 2.416 & $(7.7 \pm 16.2) \times 10^{-4}$ & $0.010 \pm 0.005$ & $(5.9 \pm 2.9) \times 10^{-4}$ & $(1.6 \pm 0.8) \times 10^{-3}$ & $0.014 \pm 0.007$ & $(5.0 \pm 2.5) \times 10^{-3}$ \\
\hline Cyclopentanone & $\mathrm{C}_{5} \mathrm{H}_{8} \mathrm{O}$ & 799.75 & 2.583 & $0.011 \pm 0.005$ & $0.034 \pm 0.017$ & $(1.3 \pm 0.7) \times 10^{-3}$ & $(7.6 \pm 3.8) \times 10^{-3}$ & $0.025 \pm 0.013$ & $0.030 \pm 0.015$ \\
\hline 2,3-Pentanedione & $\mathrm{C}_{5} \mathrm{H}_{8} \mathrm{O}_{2}$ & 534.835 & 2.178 & $(9.7 \pm 4.9) \times 10^{-3}$ & $0.026 \pm 0.013$ & $(6.0 \pm 3.0) \times 10^{-4}$ & $(6.9 \pm 3.5) \times 10^{-3}$ & $0.015 \pm 0.008$ & $(4.1 \pm 2.0) \times 10^{-3}$ \\
\hline 2-Butanone, 3-methyl- & $\mathrm{C}_{5} \mathrm{H}_{10} \mathrm{O}$ & 444.864 & 1.597 & $(6.3 \pm 16.2) \times 10^{-4}$ & $0.011 \pm 0.006$ & $(5.4 \pm 2.7) \times 10^{-4}$ & $(2.7 \pm 1.4) \times 10^{-3}$ & $(7.1 \pm 3.5) \times 10^{-3}$ & $0.050 \pm 0.025$ \\
\hline 2-Pentanone & $\mathrm{C}_{5} \mathrm{H}_{10} \mathrm{O}$ & 509.843 & 1.734 & $(4.5 \pm 1.6) \times 10^{-3}$ & $0.019 \pm 0.004$ & - & $(2.3 \pm 0.9) \times 10^{-3}$ & $0.017 \pm 0.003$ & $0.016 \pm 0.006$ \\
\hline 3-Pentanone & $\mathrm{C}_{5} \mathrm{H}_{10} \mathrm{O}$ & 534.835 & 1.698 & - & - & - & - & $(6.3 \pm 3.1) \times 10^{-3}$ & - \\
\hline 2-Cyclopenten-1-one, 2-methyl- & $\mathrm{C}_{6} \mathrm{H}_{8} \mathrm{O}$ & 1139.64 & 2.966 & $(6.0 \pm 3.0) \times 10^{-3}$ & $0.019 \pm 0.009$ & $(2.5 \pm 1.3) \times 10^{-3}$ & $(5.2 \pm 2.6) \times 10^{-3}$ & $0.026 \pm 0.013$ & $0.022 \pm 0.011$ \\
\hline 2-Cyclohexen-1-one & $\mathrm{C}_{6} \mathrm{H}_{8} \mathrm{O}$ & 1219.62 & 3.348 & - & - & - & - & $(2.4 \pm 1.2) \times 10^{-3}$ & - \\
\hline 2-Cyclopenten-1-one, 3-methyl- & $\mathrm{C}_{6} \mathrm{H}_{8} \mathrm{O}$ & 1314.59 & 3.762 & - & - & - & - & $(4.8 \pm 2.4) \times 10^{-3}$ & - \\
\hline 2-Pentanone, 3-methylene- & $\mathrm{C}_{6} \mathrm{H}_{10} \mathrm{O}$ & 734.771 & 1.817 & - & - & - & - & $(8.9 \pm 4.5) \times 10^{-4}$ & - \\
\hline 1-Penten-3-one, 2-methyl- & $\mathrm{C}_{6} \mathrm{H}_{10} \mathrm{O}$ & 749.766 & 1.773 & - & - & - & - & $(1.7 \pm 0.8) \times 10^{-3}$ & - \\
\hline 5-Hexen-3-one & $\mathrm{C}_{6} \mathrm{H}_{10} \mathrm{O}$ & 759.763 & 2.046 & - & - & - & - & $(4.6 \pm 2.3) \times 10^{-4}$ & - \\
\hline 5-Hexen-2-one & $\mathrm{C}_{6} \mathrm{H}_{10} \mathrm{O}$ & 759.763 & 2.138 & - & $(1.8 \pm 1.4) \times 10^{-3}$ & - & - & $(9.2 \pm 4.6) \times 10^{-4}$ & - \\
\hline 1-Hexen-3-one & $\mathrm{C}_{6} \mathrm{H}_{10} \mathrm{O}$ & 764.762 & 1.91 & - & - & - & - & $(5.8 \pm 3.0) \times 10^{-4}$ & - \\
\hline 4-Hexen-2-one & $\mathrm{C}_{6} \mathrm{H}_{10} \mathrm{O}$ & 789.754 & 1.83 & - & - & - & - & $(6.4 \pm 3.2) \times 10^{-4}$ & - \\
\hline 4-Penten-2-one, 3-methyl- & $\mathrm{C}_{6} \mathrm{H}_{10} \mathrm{O}$ & 834.739 & 2.134 & - & $(1.5 \pm 1.4) \times 10^{-3}$ & - & - & $(7.9 \pm 3.9) \times 10^{-4}$ & - \\
\hline 3-Penten-2-one, 4-methyl- & $\mathrm{C}_{6} \mathrm{H}_{10} \mathrm{O}$ & 839.738 & 1.984 & - & - & - & - & $(5.6 \pm 2.8) \times 10^{-4}$ & - \\
\hline 4-Hexen-3-one isomer & $\mathrm{C}_{6} \mathrm{H}_{10} \mathrm{O}$ & 859.731 & 2.187 & - & - & - & - & $(5.3 \pm 2.6) \times 10^{-4}$ & - \\
\hline 4-Hexen-3-one isomer & $\mathrm{C}_{6} \mathrm{H}_{10} \mathrm{O}$ & 939.706 & 2.121 & - & - & - & - & $(2.2 \pm 1.1) \times 10^{-3}$ & - \\
\hline Cyclopentanone, 2-methyl- & $\mathrm{C}_{6} \mathrm{H}_{10} \mathrm{O}$ & 949.702 & 2.156 & - & $(8.1 \pm 4.1) \times 10^{-3}$ & - & - & $(7.9 \pm 4.0) \times 10^{-3}$ & - \\
\hline 3-Penten-2-one, 3-methyl- & $\mathrm{C}_{6} \mathrm{H}_{10} \mathrm{O}$ & 954.701 & 2.134 & - & $(1.2 \pm 1.4) \times 10^{-3}$ & - & - & - & - \\
\hline 3-Hexen-2-one & $\mathrm{C}_{6} \mathrm{H}_{10} \mathrm{O}$ & 964.698 & 2.187 & - & - & - & - & $(10.0 \pm 5.0) \times 10^{-4}$ & - \\
\hline 3-Methylcyclopentanone & $\mathrm{C}_{6} \mathrm{H}_{10} \mathrm{O}$ & 974.694 & 2.248 & - & - & - & - & $(3.3 \pm 1.6) \times 10^{-3}$ & - \\
\hline Cyclohexanone & $\mathrm{C}_{6} \mathrm{H}_{10} \mathrm{O}$ & 1109.65 & 2.473 & - & $(6.9 \pm 1.5) \times 10^{-3}$ & - & $(1.6 \pm 0.7) \times 10^{-3}$ & $(1.7 \pm 0.3) \times 10^{-3}$ & $0.015 \pm 0.004$ \\
\hline $\mathrm{C}_{6}$ Diketone isomer & $\mathrm{C}_{6} \mathrm{H}_{10} \mathrm{O}_{2}$ & 664.794 & 1.738 & - & - & - & - & - & $(8.1 \pm 6.0) \times 10^{-3}$ \\
\hline $\mathrm{C}_{6}$ Diketone isomer & $\mathrm{C}_{6} \mathrm{H}_{10} \mathrm{O}_{2}$ & 789.754 & 1.976 & $(1.1 \pm 0.5) \times 10^{-3}$ & $(2.3 \pm 1.4) \times 10^{-3}$ & $(2.9 \pm 4.1) \times 10^{-4}$ & $(1.1 \pm 0.6) \times 10^{-3}$ & $(1.9 \pm 1.0) \times 10^{-3}$ & - \\
\hline $\mathrm{C}_{6}$ Diketone isomer & $\mathrm{C}_{6} \mathrm{H}_{10} \mathrm{O}_{2}$ & 829.741 & 1.932 & - & - & - & - & $(6.2 \pm 3.1) \times 10^{-4}$ & - \\
\hline $\mathrm{C}_{6}$ Diketone isomer & $\mathrm{C}_{6} \mathrm{H}_{10} \mathrm{O}_{2}$ & 874.726 & 1.852 & $0.013 \pm 0.006$ & - & - & - & $(3.2 \pm 1.6) \times 10^{-3}$ & $(4.1 \pm 4.0) \times 10^{-3}$ \\
\hline Methyl Isobutyl Ketone & $\mathrm{C}_{6} \mathrm{H}_{12} \mathrm{O}$ & 664.794 & 1.61 & - & $(4.3 \pm 3.0) \times 10^{-3}$ & - & - & $(9.5 \pm 6.6) \times 10^{-4}$ & $0.011 \pm 0.009$ \\
\hline 3-Pentanone, 2-methyl- & $\mathrm{C}_{6} \mathrm{H}_{12} \mathrm{O}$ & 689.786 & 1.536 & - & - & - & - & $(2.7 \pm 3.0) \times 10^{-4}$ & $(6.4 \pm 3.2) \times 10^{-3}$ \\
\hline 2-Pentanone, 3-methyl- & $\mathrm{C}_{6} \mathrm{H}_{12} \mathrm{O}$ & 699.782 & 1.61 & - & - & - & - & $(9.5 \pm 4.7) \times 10^{-4}$ & $0.020 \pm 0.01$ \\
\hline 3-Hexanone & $\mathrm{C}_{6} \mathrm{H}_{12} \mathrm{O}$ & 784.755 & 1.628 & - & - & - & - & $(2.0 \pm 1.0) \times 10^{-3}$ & 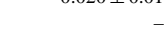 \\
\hline 2-Hexanone & $\mathrm{C}_{6} \mathrm{H}_{12} \mathrm{O}$ & 804.749 & 1.729 & $(2.6 \pm 1.2) \times 10^{-3}$ & $(5.7 \pm 1.4) \times 10^{-3}$ & - & - & $(2.6 \pm 0.5) \times 10^{-3}$ & $0.011 \pm 0.004$ \\
\hline Cyclopentanone, 3,4-bis(methylene)- & $\mathrm{C}_{7} \mathrm{H}_{8} \mathrm{O}$ & 1289.59 & 2.873 & 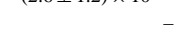 & (1) & - & - & $(8.5 \pm 4.3) \times 10^{-4}$ & - \\
\hline 2-Cyclopenten-1-one, 3,4-dimethyl- & $\mathrm{C}_{7} \mathrm{H}_{10} \mathrm{O}$ & 1229.61 & 2.358 & - & $(4.1 \pm 2.0) \times 10^{-3}$ & - & - & $(4.5 \pm 2.3) \times 10^{-3}$ & - \\
\hline 3-Methyl-3-cyclohexen-1-one & $\mathrm{C}_{7} \mathrm{H}_{10} \mathrm{O}$ & 1254.6 & 2.407 & - & - & - & - & $(1.8 \pm 0.9) \times 10^{-3}$ & - \\
\hline 2-Cyclopenten-1-one, 2,3-dimethyl- & $\mathrm{C}_{7} \mathrm{H}_{10} \mathrm{O}$ & 1389.56 & 2.618 & - & - & - & - & $(3.3 \pm 1.6) \times 10^{-3}$ & - \\
\hline $\mathrm{C}_{7} \mathrm{H}_{10} \mathrm{O}$ isomer & $\mathrm{C}_{7} \mathrm{H}_{10} \mathrm{O}$ & 1514.52 & 2.917 & - & - & - & - & $(1.6 \pm 0.8) \times 10^{-3}$ & - \\
\hline Cyclopentanone, 2-ethyl- & $\mathrm{C}_{7} \mathrm{H}_{12} \mathrm{O}$ & 1234.61 & 2.033 & - & - & - & - & $(9.4 \pm 4.7) \times 10^{-4}$ & - \\
\hline 3-Pentanone, 2,4-dimethyl & $\mathrm{C}_{7} \mathrm{H}_{14} \mathrm{O}$ & 664.794 & 1.747 & $(5.3 \pm 2.7) \times 10^{-3}$ & - & $(3.4 \pm 1.7) \times 10^{-3}$ & - & $(1.5 \pm 0.8) \times 10^{-3}$ & $(8.0 \pm 4.0) \times 10^{-3}$ \\
\hline 2-Heptanone & $\mathrm{C}_{7} \mathrm{H}_{14} \mathrm{O}$ & 1094.66 & 1.694 & - & $(2.4 \pm 1.4) \times 10^{-3}$ & - & - & $(9.7 \pm 4.8) \times 10^{-4}$ & $(8.6 \pm 4.3) \times 10^{-3}$ \\
\hline \multicolumn{10}{|l|}{ Esters } \\
\hline Acetic acid, methyl ester & $\mathrm{C}_{3} \mathrm{H}_{6} \mathrm{O}_{2}$ & 209.939 & 1.342 & $0.024 \pm 0.012$ & $0.047 \pm 0.024$ & $(6.4 \pm 3.2) \times 10^{-3}$ & $0.029 \pm 0.014$ & $0.039 \pm 0.019$ & $0.080 \pm 0.04$ \\
\hline Acetic acid ethenyl ester & $\mathrm{C}_{4} \mathrm{H}_{6} \mathrm{O}_{2}$ & 279.917 & 1.619 & $(6.1 \pm 3.1) \times 10^{-3}$ & $(3.4 \pm 1.7) \times 10^{-3}$ & - & - & - & - \\
\hline Ethyl Acetate & $\mathrm{C}_{4} \mathrm{H}_{8} \mathrm{O}_{2}$ & 339.898 & 1.527 & - & - & - & - & $(5.3 \pm 2.7) \times 10^{-4}$ & 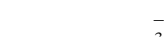 \\
\hline 2-Propenoic acid, methyl ester & $\mathrm{C}_{4} \mathrm{H}_{6} \mathrm{O}_{2}$ & 344.896 & 1.817 & $(6.1 \pm 3.1) \times 10^{-3}$ & $(9.4 \pm 4.7) \times 10^{-3}$ & - & $(1.6 \pm 0.8) \times 10^{-3}$ & $(2.5 \pm 1.2) \times 10^{-3}$ & $(7.2 \pm 3.6) \times 10^{-3}$ \\
\hline Butyrolactone & $\mathrm{C}_{4} \mathrm{H}_{6} \mathrm{O}_{2}$ & 1159.64 & 2.68 & - & $(7.3 \pm 3.7) \times 10^{-3}$ & $(7.0 \pm 3.5) \times 10^{-4}$ & - & $0.015 \pm 0.008$ & - \\
\hline Acetic anhydride & $\mathrm{C}_{4} \mathrm{H}_{6} \mathrm{O}_{3}$ & 789.754 & 3.353 & $0.012 \pm 0.006$ & $0.018 \pm 0.009$ & - & $(2.7 \pm 1.3) \times 10^{-3}$ & $(7.4 \pm 3.7) \times 10^{-3}$ & - \\
\hline Methyl propionate & $\mathrm{C}_{4} \mathrm{H}_{8} \mathrm{O}_{2}$ & 369.888 & 1.571 & $(2.3 \pm 1.1) \times 10^{-3}$ & $(5.8 \pm 2.9) \times 10^{-3}$ & - & $(2.9 \pm 1.4) \times 10^{-3}$ & $(4.3 \pm 2.2) \times 10^{-3}$ & $(9.2 \pm 4.6) \times 10^{-3}$ \\
\hline 2(3H)-Furanone, 5-methyl- & $\mathrm{C}_{5} \mathrm{H}_{6} \mathrm{O}_{2}$ & 1044.67 & 4.343 & - & $(3.1 \pm 1.5) \times 10^{-3}$ & - & $(7.6 \pm 3.8) \times 10^{-4}$ & - & - \\
\hline Acetic acid, 2-propenyl ester & $\mathrm{C}_{5} \mathrm{H}_{8} \mathrm{O}_{2}$ & 544.832 & 1.94 & $(3.6 \pm 1.8) \times 10^{-3}$ & $(3.8 \pm 1.9) \times 10^{-3}$ & - & - & $(1.1 \pm 0.6) \times 10^{-3}$ & - \\
\hline Methacrylic acid methyl ester & $\mathrm{C}_{5} \mathrm{H}_{8} \mathrm{O}_{2}$ & 579.821 & 1.716 & $(2.3 \pm 1.1) \times 10^{-3}$ & $(6.2 \pm 3.1) \times 10^{-3}$ & - & - & - & - \\
\hline 2-Butenoic acid, methyl ester & $\mathrm{C}_{5} \mathrm{H}_{8} \mathrm{O}_{2}$ & 739.77 & 2.02 & - & - & - & - & $(7.6 \pm 3.8) \times 10^{-4}$ & - \\
\hline Butanoic acid, methyl ester & $\mathrm{C}_{5} \mathrm{H}_{10} \mathrm{O}_{2}$ & 604.813 & 1.584 & - & $(2.8 \pm 1.4) \times 10^{-3}$ & - & $(1.4 \pm 0.7) \times 10^{-3}$ & $(1.5 \pm 0.8) \times 10^{-3}$ & - \\
\hline 2-Vinylethyl acetate & $\mathrm{C}_{6} \mathrm{H}_{10} \mathrm{O}_{2}$ & 814.746 & 1.839 & $(1.8 \pm 0.9) \times 10^{-3}$ & - & - & - & - & - \\
\hline Acetic acid, butyl ester & $\mathrm{C}_{6} \mathrm{H}_{12} \mathrm{O}_{2}$ & 869.728 & 1.549 & - & $(3.4 \pm 1.7) \times 10^{-3}$ & - & - & - & - \\
\hline Isobutyric acid, allyl ester & $\mathrm{C}_{7} \mathrm{H}_{12} \mathrm{O}_{2}$ & 979.693 & 4.25 & - & - & $(9.1 \pm 4.5) \times 10^{-4}$ & - & - & - \\
\hline \multicolumn{10}{|l|}{ Alcohols } \\
\hline Isopropyl Alcohol & $\mathrm{C}_{3} \mathrm{H}_{8} \mathrm{O}$ & 174.95 & 1.795 & $(2.6 \pm 1.2) \times 10^{-3}$ & - & $(4.8 \pm 1.0) \times 10^{-3}$ & - & $(7.5 \pm 1.5) \times 10^{-3}$ & - \\
\hline 2-Propen-1-ol & $\mathrm{C}_{3} \mathrm{H}_{6} \mathrm{O}$ & 219.936 & 4.255 & $0.016 \pm 0.008$ & $0.023 \pm 0.012$ & $(1.0 \pm 0.5) \times 10^{-3}$ & $(2.7 \pm 1.3) \times 10^{-3}$ & $(6.5 \pm 3.3) \times 10^{-3}$ & - \\
\hline 1-Butanol & $\mathrm{C}_{4} \mathrm{H}_{10} \mathrm{O}$ & 429.869 & 3.731 & $(7.0 \pm 2.3) \times 10^{-3}$ & $0.030 \pm 0.021$ & $(5.3 \pm 1.1) \times 10^{-3}$ & $0.018 \pm 0.004$ & $(5.8 \pm 1.2) \times 10^{-3}$ & - \\
\hline \multicolumn{10}{|l|}{ Other } \\
\hline 2H-Pyran, 3,4-dihydro- & $\mathrm{C}_{5} \mathrm{H}_{8} \mathrm{O}$ & 514.842 & 1.54 & $(1.6 \pm 0.9) \times 10^{-3}$ & $(3.0 \pm 1.5) \times 10^{-3}$ & - & $(6.8 \pm 4.8) \times 10^{-4}$ & - & - \\
\hline \multicolumn{10}{|l|}{ Furans } \\
\hline Furan & $\mathrm{C}_{4} \mathrm{H}_{4} \mathrm{O}$ & 179.949 & 1.236 & $0.23 \pm 0.05$ & $0.31 \pm 0.06$ & $0.022 \pm 0.004$ & $0.065 \pm 0.013$ & $0.085 \pm 0.017$ & $0.31 \pm 0.06$ \\
\hline Furan, 2,5-dihydro- & $\mathrm{C}_{4} \mathrm{H}_{6} \mathrm{O}$ & 259.923 & 1.91 & $(2.4 \pm 2.0) \times 10^{-3}$ & $(3.1 \pm 2.5) \times 10^{-3}$ & - & - & $(5.3 \pm 2.7) \times 10^{-4}$ & - \\
\hline 2,3-Dihydrofuran & $\mathrm{C}_{4} \mathrm{H}_{6} \mathrm{O}$ & 264.922 & 1.39 & $(9.9 \pm 4.9) \times 10^{-3}$ & $0.021 \pm 0.01$ & - & $0.011 \pm 0.005$ & $(5.9 \pm 3.0) \times 10^{-3}$ & $(6.1 \pm 3.1) \times 10^{-3}$ \\
\hline Furan, tetrahydro- & $\mathrm{C}_{4} \mathrm{H}_{8} \mathrm{O}$ & 364.89 & 1.412 & $(1.8 \pm 2.0) \times 10^{-3}$ & $(3.2 \pm 2.5) \times 10^{-3}$ & $(5.4 \pm 1.2) \times 10^{-4}$ & $(5.8 \pm 10.8) \times 10^{-4}$ & $(1.4 \pm 0.5) \times 10^{-3}$ & - \\
\hline Furan, 2-methyl- & $\mathrm{C}_{5} \mathrm{H}_{6} \mathrm{O}$ & 319.904 & 1.487 & $0.13 \pm 0.03$ & $0.21 \pm 0.04$ & $(8.6 \pm 1.7) \times 10^{-3}$ & $0.045 \pm 0.009$ & $0.066 \pm 0.013$ & $0.23 \pm 0.05$ \\
\hline Furan, 3-methyl- & $\mathrm{C}_{5} \mathrm{H}_{6} \mathrm{O}$ & 334.899 & 1.575 & $0.013 \pm 0.007$ & $0.022 \pm 0.011$ & $(1.2 \pm 0.6) \times 10^{-3}$ & $(5.0 \pm 2.5) \times 10^{-3}$ & $(7.6 \pm 3.8) \times 10^{-3}$ & $0.025 \pm 0.012$ \\
\hline Furan, 2,3-dihydro-5-methyl- & $\mathrm{C}_{5} \mathrm{H}_{8} \mathrm{O}$ & 459.859 & 1.456 & $(2.2 \pm 1.1) \times 10^{-3}$ & $(6.2 \pm 3.1) \times 10^{-3}$ & - & $(2.8 \pm 1.4) \times 10^{-3}$ & $(1.2 \pm 0.6) \times 10^{-3}$ & - \\
\hline
\end{tabular}


Table A1. Continued.

\begin{tabular}{|c|c|c|c|c|c|c|c|c|c|}
\hline Vinylfuran & $\mathrm{C}_{6} \mathrm{H}_{6} \mathrm{O}$ & 619.808 & 2.09 & $(6.9 \pm 3.4) \times 10^{-3}$ & $(9.5 \pm 4.8) \times 10^{-3}$ & $(8.7 \pm 4.4) \times 10^{-4}$ & $(1.1 \pm 1.2) \times 10^{-3}$ & $(5.1 \pm 2.5) \times 10^{-3}$ & - \\
\hline Furan, 2-ethyl- & $\mathrm{C}_{6} \mathrm{H}_{8} \mathrm{O}$ & 544.832 & 1.531 & $(6.9 \pm 3.4) \times 10^{-3}$ & $0.012 \pm 0.006$ & $(1.0 \pm 0.5) \times 10^{-3}$ & $(1.1 \pm 1.2) \times 10^{-3}$ & $(6.8 \pm 3.4) \times 10^{-3}$ & $0.012 \pm 0.008$ \\
\hline Furan, 2,5-dimethyl- & $\mathrm{C}_{6} \mathrm{H}_{8} \mathrm{O}$ & 569.824 & 1.5 & $0.038 \pm 0.008$ & $0.079 \pm 0.016$ & $(8.7 \pm 8.3) \times 10^{-4}$ & $(8.8 \pm 1.8) \times 10^{-3}$ & $0.027 \pm 0.005$ & $0.066 \pm 0.013$ \\
\hline Furan, 3-ethyl- & $\mathrm{C}_{6} \mathrm{H}_{8} \mathrm{O}$ & 579.821 & 1.637 & $(1.5 \pm 0.8) \times 10^{-3}$ & $(2.1 \pm 1.1) \times 10^{-3}$ & - & $(6.1 \pm 3.0) \times 10^{-4}$ & $(5.3 \pm 6.0) \times 10^{-4}$ & - \\
\hline Furan, 2,4-dimethyl- & $\mathrm{C}_{6} \mathrm{H}_{8} \mathrm{O}$ & 594.816 & 1.54 & $(6.2 \pm 3.1) \times 10^{-3}$ & $0.013 \pm 0.007$ & $(6.7 \pm 3.3) \times 10^{-4}$ & $(2.0 \pm 1.2) \times 10^{-3}$ & $(3.7 \pm 1.9) \times 10^{-3}$ & $0.034 \pm 0.017$ \\
\hline Furan, 2,3-dimethyl- & $\mathrm{C}_{6} \mathrm{H}_{8} \mathrm{O}$ & 599.814 & 1.553 & $(3.5 \pm 1.7) \times 10^{-3}$ & - & - & - & $(1.8 \pm 0.9) \times 10^{-3}$ & - \\
\hline Furan, 2-(1-propenyl)- & $\mathrm{C}_{7} \mathrm{H}_{8} \mathrm{O}$ & 939.706 & 1.98 & - & - & - & - & $(6.4 \pm 3.2) \times 10^{-4}$ & - \\
\hline Furan, 2-(2-propenyl)- & $\mathrm{C}_{7} \mathrm{H}_{8} \mathrm{O}$ & 1009.68 & 2.002 & - & $(2.9 \pm 1.4) \times 10^{-3}$ & - & $(6.9 \pm 3.4) \times 10^{-4}$ & $(9.0 \pm 6.1) \times 10^{-4}$ & - \\
\hline Furan, 2-propyl- & $\mathrm{C}_{7} \mathrm{H}_{10} \mathrm{O}$ & 799.75 & 1.505 & $(9.8 \pm 4.9) \times 10^{-4}$ & $(2.0 \pm 1.0) \times 10^{-3}$ & - & - & $(3.7 \pm 6.0) \times 10^{-4}$ & - \\
\hline Furan, 2-ethyl-5-methyl- & $\mathrm{C}_{7} \mathrm{H}_{10} \mathrm{O}$ & 829.741 & 1.452 & $(5.4 \pm 2.7) \times 10^{-3}$ & $0.010 \pm 0.005$ & - & $(0.9 \pm 12.3) \times 10^{-4}$ & $(6.0 \pm 3.0) \times 10^{-3}$ & $0.014 \pm 0.008$ \\
\hline Furan, 2,3,5-trimethyl- & $\mathrm{C}_{7} \mathrm{H}_{10} \mathrm{O}$ & 889.722 & 1.474 & $(3.0 \pm 1.5) \times 10^{-3}$ & $(2.5 \pm 2.8) \times 10^{-3}$ & - & $(9.9 \pm 4.9) \times 10^{-4}$ & $(1.3 \pm 0.7) \times 10^{-3}$ & $(7.4 \pm 8.0) \times 10^{-3}$ \\
\hline 2-Propionylfuran & $\mathrm{C}_{7} \mathrm{H}_{8} \mathrm{O}_{2}$ & 1429.55 & 3.555 & - & - & - & - & $(1.5 \pm 0.8) \times 10^{-3}$ & - \\
\hline Furan, 4-methyl-2-propyl- & $\mathrm{C}_{8} \mathrm{H}_{12} \mathrm{O}$ & 1074.66 & 1.408 & $(9.8 \pm 4.9) \times 10^{-4}$ & - & - & - & - & - \\
\hline \multicolumn{10}{|l|}{ Aldehydes and ketones } \\
\hline 3-Furaldehyde & $\mathrm{C}_{5} \mathrm{H}_{4} \mathrm{O}_{2}$ & 869.728 & 1.012 & $0.017 \pm 0.008$ & $0.029 \pm 0.014$ & $(2.5 \pm 1.2) \times 10^{-3}$ & $(8.5 \pm 4.2) \times 10^{-3}$ & $(9.5 \pm 4.7) \times 10^{-3}$ & - \\
\hline Furfural & $\mathrm{C}_{5} \mathrm{H}_{4} \mathrm{O}_{2}$ & 934.707 & 1.131 & $0.21 \pm 0.04$ & $0.44 \pm 0.09$ & $0.021 \pm 0.004$ & $0.16 \pm 0.03$ & $0.20 \pm 0.04$ & $0.35 \pm 0.07$ \\
\hline Furan, 2-acetyl- & $\mathrm{C}_{6} \mathrm{H}_{6} \mathrm{O}_{2}$ & 1164.63 & 4.484 & $(6.6 \pm 3.3) \times 10^{-3}$ & $0.018 \pm 0.009$ & $(2.1 \pm 1.0) \times 10^{-3}$ & $(6.0 \pm 3.0) \times 10^{-3}$ & $0.018 \pm 0.009$ & - \\
\hline 5-methyl furfural & $\mathrm{C}_{6} \mathrm{H}_{6} \mathrm{O}_{2}$ & 1309.59 & 4.396 & $0.013 \pm 0.003$ & $0.034 \pm 0.007$ & - & $(7.2 \pm 1.4) \times 10^{-3}$ & $0.042 \pm 0.008$ & $0.051 \pm 0.01$ \\
\hline Methyl 2-furoate & $\mathrm{C}_{6} \mathrm{H}_{6} \mathrm{O}_{3}$ & 1344.58 & 4.088 & - & - & - & - & $(1.6 \pm 0.8) \times 10^{-3}$ & - \\
\hline 2-Acetyl-5-methylfuran & $\mathrm{C}_{7} \mathrm{H}_{8} \mathrm{O}_{2}$ & 1509.52 & 3.542 & - & - & - & - & $(1.9 \pm 1.0) \times 10^{-3}$ & - \\
\hline \multicolumn{10}{|l|}{ Alcohols } \\
\hline 2-Furan methanol & $\mathrm{C}_{5} \mathrm{H}_{6} \mathrm{O}_{2}$ & 984.691 & 3.309 & $0.043 \pm 0.009$ & $0.13 \pm 0.03$ & $0.010 \pm 0.002$ & $0.071 \pm 0.014$ & $0.12 \pm 0.02$ & - \\
\hline \multicolumn{10}{|l|}{$\mathrm{N}$ - and S-containing compounds } \\
\hline \multicolumn{10}{|l|}{ Nitriles } \\
\hline Acetonitrile & $\mathrm{C}_{2} \mathrm{H}_{3} \mathrm{~N}$ & 169.952 & 2.592 & $0.018 \pm 0.004$ & $0.031 \pm 0.006$ & $0.021 \pm 0.004$ & - & $0.021 \pm 0.004$ & $0.064 \pm 0.013$ \\
\hline Acrylonitrile & $\mathrm{C}_{3} \mathrm{H}_{3} \mathrm{~N}$ & 199.942 & 2.433 & $0.018 \pm 0.004$ & $0.031 \pm 0.006$ & $0.020 \pm 0.004$ & $(1.6 \pm 0.7) \times 10^{-3}$ & $(9.5 \pm 1.9) \times 10^{-3}$ & $0.018 \pm 0.005$ \\
\hline Propanenitrile & $\mathrm{C}_{3} \mathrm{H}_{5} \mathrm{~N}$ & 269.92 & 2.873 & $(9.8 \pm 4.9) \times 10^{-3}$ & $0.018 \pm 0.009$ & $(5.9 \pm 2.9) \times 10^{-3}$ & $(1.3 \pm 0.7) \times 10^{-3}$ & $(9.1 \pm 4.5) \times 10^{-3}$ & $0.024 \pm 0.012$ \\
\hline Methacrylonitrile & $\mathrm{C}_{4} \mathrm{H}_{5} \mathrm{~N}$ & 309.907 & 2.306 & $(7.5 \pm 1.5) \times 10^{-3}$ & $0.011 \pm 0.002$ & $(4.1 \pm 0.8) \times 10^{-3}$ & - & $(5.1 \pm 1.0) \times 10^{-3}$ & $0.013 \pm 0.004$ \\
\hline 3-Butenenitrile & $\mathrm{C}_{4} \mathrm{H}_{5} \mathrm{~N}$ & 409.875 & 3.221 & $(4.2 \pm 2.1) \times 10^{-3}$ & $(8.0 \pm 4.0) \times 10^{-3}$ & $(3.0 \pm 1.5) \times 10^{-3}$ & - & $(3.6 \pm 1.8) \times 10^{-3}$ & - \\
\hline 2-Butenenitrile & $\mathrm{C}_{4} \mathrm{H}_{5} \mathrm{~N}$ & 494.848 & 3.705 & - & $(5.6 \pm 2.8) \times 10^{-3}$ & $(2.2 \pm 1.1) \times 10^{-3}$ & - & $(2.6 \pm 1.3) \times 10^{-3}$ & - \\
\hline Isobutyronitrile & $\mathrm{C}_{4} \mathrm{H}_{7} \mathrm{~N}$ & 359.891 & 2.332 & $(5.8 \pm 2.9) \times 10^{-3}$ & $(9.3 \pm 4.6) \times 10^{-3}$ & $(2.4 \pm 1.2) \times 10^{-3}$ & - & $(4.0 \pm 2.0) \times 10^{-3}$ & $0.018 \pm 0.009$ \\
\hline Butanenitrile & $\mathrm{C}_{4} \mathrm{H}_{7} \mathrm{~N}$ & 464.858 & 2.988 & $(3.7 \pm 1.9) \times 10^{-3}$ & $(5.2 \pm 2.6) \times 10^{-3}$ & $(1.4 \pm 0.7) \times 10^{-3}$ & - & $(2.7 \pm 1.3) \times 10^{-3}$ & $0.013 \pm 0.006$ \\
\hline 2,4-Pentadienenitrile & $\mathrm{C}_{5} \mathrm{H}_{5} \mathrm{~N}$ & 684.787 & 4.176 & - & - & $(1.1 \pm 0.5) \times 10^{-3}$ & - & (2.) & - \\
\hline Butanenitrile, 2-methylene- & $\mathrm{C}_{5} \mathrm{H}_{7} \mathrm{~N}$ & 614.81 & 2.319 & - & - & - & - & $(1.3 \pm 0.6) \times 10^{-3}$ & - \\
\hline 3-Butenenitrile, 3-methyl- & $\mathrm{C}_{5} \mathrm{H}_{7} \mathrm{~N}$ & 759.763 & 3.106 & - & - & - & - & $(1.4 \pm 0.7) \times 10^{-3}$ & - \\
\hline Butanenitrile, 2-methyl- & $\mathrm{C}_{5} \mathrm{H}_{9} \mathrm{~N}$ & 609.811 & 2.288 & $(4.4 \pm 2.2) \times 10^{-3}$ & $(6.0 \pm 3.0) \times 10^{-3}$ & $(1.3 \pm 0.7) \times 10^{-3}$ & - & $(2.0 \pm 1.0) \times 10^{-3}$ & $0.016 \pm 0.008$ \\
\hline Butanenitrile, 3-methyl- & $\mathrm{C}_{5} \mathrm{H}_{9} \mathrm{~N}$ & 624.806 & 2.583 & $(5.9 \pm 2.9) \times 10^{-3}$ & $0.011 \pm 0.005$ & $(2.2 \pm 1.1) \times 10^{-3}$ & - & $(4.8 \pm 2.4) \times 10^{-3}$ & $0.019 \pm 0.009$ \\
\hline Pentanenitrile & $\mathrm{C}_{5} \mathrm{H}_{9} \mathrm{~N}$ & 754.765 & 2.794 & - & - & - & - & $(1.0 \pm 0.5) \times 10^{-3}$ & - \\
\hline Pentanenitrile, 4-methyl- & $\mathrm{C}_{6} \mathrm{H}_{11} \mathrm{~N}$ & 954.701 & 2.486 & $(3.8 \pm 1.9) \times 10^{-3}$ & $(5.7 \pm 2.9) \times 10^{-3}$ & $(1.5 \pm 0.7) \times 10^{-3}$ & - & $(2.7 \pm 1.4) \times 10^{-3}$ & - \\
\hline Benzonitrile & $\mathrm{C}_{7} \mathrm{H}_{5} \mathrm{~N}$ & 1369.57 & 4.541 & $0.017 \pm 0.003$ & $0.026 \pm 0.005$ & $0.037 \pm 0.007$ & $(4.5 \pm 1.4) \times 10^{-3}$ & $0.013 \pm 0.003$ & $0.064 \pm 0.013$ \\
\hline Benzonitrile, 3-methyl- & $\mathrm{C}_{8} \mathrm{H}_{7} \mathrm{~N}$ & 1599.49 & 3.577 & - & - & $(2.5 \pm 1.3) \times 10^{-3}$ & - & - & - \\
\hline \multicolumn{10}{|l|}{ Pyrroles } \\
\hline Pyrrole & $\mathrm{C}_{4} \mathrm{H}_{5} \mathrm{~N}$ & 694.784 & 4.602 & $0.042 \pm 0.008$ & $0.11 \pm 0.02$ & $0.023 \pm 0.005$ & $0.014 \pm 0.003$ & $0.050 \pm 0.01$ & $0.055 \pm 0.011$ \\
\hline 1H-Pyrrole, 1-methyl- & $\mathrm{C}_{5} \mathrm{H}_{7} \mathrm{~N}$ & 664.794 & 2.574 & $0.011 \pm 0.005$ & $0.021 \pm 0.011$ & $(2.3 \pm 1.2) \times 10^{-3}$ & $(4.1 \pm 2.0) \times 10^{-3}$ & $(5.7 \pm 2.9) \times 10^{-3}$ & $0.031 \pm 0.016$ \\
\hline 1H-Pyrrole, 2-methyl- & $\mathrm{C}_{5} \mathrm{H}_{7} \mathrm{~N}$ & 934.707 & 4.167 & $(4.9 \pm 3.1) \times 10^{-3}$ & $0.015 \pm 0.008$ & $(2.3 \pm 1.1) \times 10^{-3}$ & - & $(6.8 \pm 3.4) \times 10^{-3}$ & $0.018 \pm 0.011$ \\
\hline 1H-Pyrrole, 3-methyl- & $\mathrm{C}_{5} \mathrm{H}_{7} \mathrm{~N}$ & 959.699 & 4.294 & - & $(5.4 \pm 3.7) \times 10^{-3}$ & - & - & $(3.8 \pm 1.9) \times 10^{-3}$ & - \\
\hline 1H-Pyrrole, 1-ethyl- & $\mathrm{C}_{6} \mathrm{H}_{9} \mathrm{~N}$ & 874.726 & 2.235 & - & $(6.2 \pm 3.7) \times 10^{-3}$ & - & - & $(1.6 \pm 0.8) \times 10^{-3}$ & - \\
\hline 1H-Pyrrole, 2,4-dimethyl- & $\mathrm{C}_{6} \mathrm{H}_{9} \mathrm{~N}$ & 949.702 & 2.218 & - & - & - & - & $(1.4 \pm 0.8) \times 10^{-3}$ & - \\
\hline 1H-Pyrrole, 2,5-dimethyl- & $\mathrm{C}_{6} \mathrm{H}_{9} \mathrm{~N}$ & 1044.67 & 2.398 & - & $(5.9 \pm 3.7) \times 10^{-3}$ & - & - & $(1.2 \pm 0.8) \times 10^{-3}$ & $0.014 \pm 0.011$ \\
\hline 1H-Pyrrole, 2-ethyl- & $\mathrm{C}_{6} \mathrm{H}_{9} \mathrm{~N}$ & 1174.63 & 1.822 & - & - & - & - & $(1.1 \pm 0.8) \times 10^{-3}$ & - \\
\hline \multicolumn{10}{|l|}{ Pyridines } \\
\hline Pyridine & $\mathrm{C}_{5} \mathrm{H}_{5} \mathrm{~N}$ & 674.79 & 2.992 & $0.014 \pm 0.003$ & $0.030 \pm 0.006$ & $0.022 \pm 0.004$ & $(4.2 \pm 0.9) \times 10^{-3}$ & $0.019 \pm 0.004$ & $0.12 \pm 0.02$ \\
\hline Pyridine, 2-methyl- & $\mathrm{C}_{6} \mathrm{H}_{7} \mathrm{~N}$ & 889.722 & 2.442 & - & $(5.8 \pm 2.9) \times 10^{-3}$ & $(2.0 \pm 1.0) \times 10^{-3}$ & - & $(6.1 \pm 3.0) \times 10^{-3}$ & $0.020 \pm 0.01$ \\
\hline Pyridine, 3-methyl- & $\mathrm{C}_{6} \mathrm{H}_{7} \mathrm{~N}$ & 1024.68 & 2.684 & - & - & - & - & $(2.4 \pm 1.2) \times 10^{-3}$ & - \\
\hline \multicolumn{10}{|l|}{ Thiophenes } \\
\hline Thiophene & $\mathrm{C}_{4} \mathrm{H}_{4} \mathrm{~S}$ & 464.858 & 2.174 & $(3.6 \pm 1.0) \times 10^{-3}$ & $(4.6 \pm 1.2) \times 10^{-3}$ & $(6.9 \pm 1.4) \times 10^{-3}$ & - & $(2.6 \pm 0.5) \times 10^{-3}$ & $0.010 \pm 0.004$ \\
\hline Thiophene, 2-methyl- & $\mathrm{C}_{5} \mathrm{H}_{6} \mathrm{~S}$ & 754.765 & 1.954 & - & $(1.9 \pm 1.2) \times 10^{-3}$ & - & - & $(7.9 \pm 4.0) \times 10^{-4}$ & $(6.7 \pm 3.5) \times 10^{-3}$ \\
\hline Thiophene, 3-methyl- & $\mathrm{C}_{5} \mathrm{H}_{6} \mathrm{~S}$ & 779.757 & 2.064 & - & - & - & - & $(6.1 \pm 3.0) \times 10^{-4}$ & - \\
\hline Benzo[a]thiophene & $\mathrm{C}_{8} \mathrm{H}_{6} \mathrm{~S}$ & 1914.39 & 3.428 & - & - & $(3.6 \pm 0.7) \times 10^{-3}$ & - & - & - \\
\hline \multicolumn{10}{|l|}{ Other } \\
\hline Pyrazine & $\mathrm{C}_{4} \mathrm{H}_{4} \mathrm{~N}_{2}$ & 629.805 & 3.665 & - & - & - & - & $(2.9 \pm 1.4) \times 10^{-3}$ & - \\
\hline Pyrazine, methyl- & $\mathrm{C}_{5} \mathrm{H}_{6} \mathrm{~N}_{2}$ & 904.717 & 2.86 & - & - & - & - & $(3.4 \pm 1.7) \times 10^{-3}$ & - \\
\hline 3-Methylpyridazine & $\mathrm{C}_{5} \mathrm{H}_{6} \mathrm{~N}_{2}$ & 1074.66 & 3.863 & $(7.1 \pm 3.5) \times 10^{-3}$ & $0.013 \pm 0.007$ & - & - & $(5.9 \pm 3.0) \times 10^{-3}$ & - \\
\hline Total emission factor & & & & $8.24 \pm 2.5$ & $11.5 \pm 3.4$ & $1.42 \pm 0.36$ & $1.07 \pm 0.32$ & $3.38 \pm 1.0$ & $14.6 \pm 4.3$ \\
\hline No. positively identified & & & & 127 & 140 & 68 & 64 & 118 & 126 \\
\hline No. tentatively identified & & & & 282 & 334 & 81 & 65 & 282 & 249 \\
\hline Total no. of compounds identified & & & & 409 & 474 & 149 & 129 & 400 & 375 \\
\hline Percent positively identified & & & & $31 \%$ & $30 \%$ & $46 \%$ & $50 \%$ & $30 \%$ & $34 \%$ \\
\hline
\end{tabular}

$\mathrm{NA}=$ not available. 


\section{The Supplement related to this article is available online at doi:10.5194/acp-15-1865-2015-supplement.}

Acknowledgements. Melissa Roskamp (Portland State University) is thanked for assisting with the sampling preparations and testing the ozone scrubbing efficiency of the sodium-thiosulfateimpregnated filters. Additional assistance from Lorne Isabelle (Portland State University) is also appreciated. Sonia Kreidenweis and Paul DeMott (Colorado State University) are thanked for helping with the coordination of the FLAME-4 campaign. This work was supported by a National Science Foundation Atmospheric and Geospace Sciences Postdoctoral Research Fellowship (grant no. 1231128) and by NASA Earth Science Division Award NNX13AP46G. Additionally, FLAME-4, C. E. Stockwell, and R. J. Yokelson were supported by NSF grant ATM-0936321.

Edited by: S. A. Nizkorodov

\section{References}

Aiken, A. C., Decarlo, P. F., Kroll, J. H., Worsnop, D. R., Huffman, J. A., Docherty, K. S., Ulbrich, I. M., Mohr, C., Kimmel, J. R., Sueper, D., Sun, Y., Zhang, Q., Trimborn, A., Northway, M., Ziemann, P. J., Canagaratna, M. R., Onasch, T. B., Alfarra, M. R., Prevot, A. S. H., Dommen, J., Duplissy, J., Metzger, A., Baltensperger, U., and Jimenez, J. L.: O/C and OM/OC ratios of primary, secondary, and ambient organic aerosols with highresolution time-of-flight aerosol mass spectrometry, Environ. Sci. Technol., 42, 4478-4485, doi:10.1021/Es703009q, 2008.

Akagi, S. K., Yokelson, R. J., Wiedinmyer, C., Alvarado, M. J., Reid, J. S., Karl, T., Crounse, J. D., and Wennberg, P. O.: Emission factors for open and domestic biomass burning for use in atmospheric models, Atmos. Chem. Phys., 11, 4039-4072, doi:10.5194/acp-11-4039-2011, 2011.

Akagi, S. K., Craven, J. S., Taylor, J. W., McMeeking, G. R., Yokelson, R. J., Burling, I. R., Urbanski, S. P., Wold, C. E., Seinfeld, J. H., Coe, H., Alvarado, M. J., and Weise, D. R.: Evolution of trace gases and particles emitted by a chaparral fire in California, Atmos. Chem. Phys., 12, 1397-1421, doi:10.5194/acp-12-13972012, 2012.

Akagi, S. K., Yokelson, R. J., Burling, I. R., Meinardi, S., Simpson, I., Blake, D. R., McMeeking, G. R., Sullivan, A., Lee, T., Kreidenweis, S., Urbanski, S., Reardon, J., Griffith, D. W. T., Johnson, T. J., and Weise, D. R.: Measurements of reactive trace gases and variable $\mathrm{O}_{3}$ formation rates in some South Carolina biomass burning plumes, Atmos. Chem. Phys., 13, 1141-1165, doi:10.5194/acp-13-1141-2013, 2013.

Alvarado, A., Atkinson, R., and Arey, J.: Kinetics of the gas-phase reactions of $\mathrm{NO}_{3}$ radicals and $\mathrm{O}_{3}$ with 3-methyl furan and the $\mathrm{OH}$ radical yield from the $\mathrm{O}_{3}$ reaction, Int. J. Chem. Kinet., 28, 905-909, 1996.

Alvarado, M. J., Wang, C., and Prinn, R. G.: Formation of ozone and growth of aerosols in young smoke plumes from biomass burning: 2. Three-dimensional Eulerian studies, J. Geophys. Res.Atmos., 114, D09307, doi:10.1029/2008jd011186, 2009.
Anderson, A. B., Riffer, R., and Wong, A.: Monoterpenes Fatty and Resin Acids of Pinus Ponderosa and Pinus Jeffreyi, Phytochemistry, 8, 873-875, doi:10.1016/S0031-9422(00)85876-8, 1969.

Andreae, M. O. and Merlet, P.: Emission of trace gases and aerosols from biomass burning, Global Biogeochem. Cy, 15, 955-966, 2001.

Andreae, M. O., Rosenfeld, D., Artaxo, P., Costa, A. A., Frank, G. P., Longo, K. M., and Silva-Dias, M. A. F.: Smoking rain clouds over the Amazon, Science, 303, 1337-1342, doi:10.1126/Science.1092779, 2004.

Aschmann, S. M., Nishino, N., Arey, J., and Atkinson, R.: Kinetics of the reactions of $\mathrm{OH}$ radicals with 2- and 3-methylfuran, 2,3- and 2,5-dimethylfuran, and E- and Z-3-hexene-2,5-dione, and products of $\mathrm{OH}+2,5$-dimethylfuran, Environ. Sci. Technol., 45, 1859-1865, doi:10.1021/es103207k, 2011.

Aschmann, S. M., Nishino, N., Arey, J., and Atkinson, R.: Products of the OH Radical-Initiated Reactions of Furan, 2-and 3Methylfuran, and 2,3-and 2,5-Dimethylfuran in the Presence of NO, J. Phys. Chem. A, 118, 457-466, 2014.

Atkinson, R. and Arey, J.: Gas-phase tropospheric chemistry of biogenic volatile organic compounds: a review, Atmos. Environ., 37, S197-S219, 2003a.

Atkinson, R. and Arey, J.: Atmospheric Degradation of Volatile Organic Compounds, Chem. Rev., 103, 4605-4638, 2003 b.

Atkinson, R., Aschmann, S. M., and Carter, W. P. L.: Kinetics of the reaction of $\mathrm{O}_{3}$ and $\mathrm{OH}$ radicals with with Furan and Thiophene at 298+/-2K, Int. J. Chem. Kinet., 15, 51-61, 1983.

Beens, J., Tijssen, R., and Blomberg, J.: Prediction of comprehensive two-dimensional gas chromatographic separations - A theoretical and practical exercise, J. Chromatogr. A, 822, 233-251, 1998.

Bierbach, A., Barnes, I., and Becker, K. H.: Rate coefficients for the gas-phase reactions of hydroxyl radicals with furan, 2methylfuran, 2-ethylfuran, and 2,5-dimethylfuran, Atmos. Environ., 26A, 813-817, 1992.

Bierbach, A., Barnes, I., and Becker, K. H.: Product and kinetic study of the $\mathrm{OH}$-initiated gas-phase oxidation of furan, 2methylfuran, and furanaldehydes at 300K, Atmos. Environ., 29, 2651-2660, 1995.

Bouvier-Brown, N. C., Goldstein, A. H., Gilman, J. B., Kuster, W. C., and de Gouw, J. A.: In-situ ambient quantification of monoterpenes, sesquiterpenes, and related oxygenated compounds during BEARPEX 2007: implications for gas- and particle-phase chemistry, Atmos. Chem. Phys., 9, 5505-5518, doi:10.5194/acp-9-5505-2009, 2009.

Brockway, D. G. and Lewis, C. E.: Long-term effects of dormantseason prescribed fire on plant community diversity, structure and productivity in a longleaf pine wiregrass ecosystem, Forest Ecol. Manag., 96, 167-183, 1997.

Cabañas, B., Baeza, M. T., MartÍn, P., Salgado, S., Villanueva, F., Monedero, E., and Wirtz, K.: Products and Mechanism of the NO3 Reaction with Thiophene, J. Atmos. Chem., 51, 317-335, doi:10.1007/s10874-005-3580-5, 2005.

Carlton, A. G., Bhave, P. V., Napelenok, S. L., Edney, E. D., Sarwar, G., Pinder, R. W., Pouliot, G. A., and Houyoux, M.: Model Representation of Secondary Organic Aerosol in CMAQv4.7, Environ. Sci. Technol., 44, 8553-8560, doi:10.1021/es100636q, 2010. 
Chan, A. W. H., Kautzman, K. E., Chhabra, P. S., Surratt, J. D., Chan, M. N., Crounse, J. D., Kürten, A., Wennberg, P. O., Flagan, R. C., and Seinfeld, J. H.: Secondary organic aerosol formation from photooxidation of naphthalene and alkylnaphthalenes: implications for oxidation of intermediate volatility organic compounds (IVOCs), Atmos. Chem. Phys., 9, 3049-3060, doi:10.5194/acp-9-3049-2009, 2009.

Chan, A. W. H., Chan, M. N., Surratt, J. D., Chhabra, P. S., Loza, C. L., Crounse, J. D., Yee, L. D., Flagan, R. C., Wennberg, P. O., and Seinfeld, J. H.: Role of aldehyde chemistry and $\mathrm{NO}_{\mathrm{x}}$ concentrations in secondary organic aerosol formation, Atmos. Chem. Phys., 10, 7169-7188, doi:10.5194/acp-10-7169-2010, 2010.

Chan, K. M., Huang, D. D., Li, Y. J., Chan, M. N., Seinfeld, J. H., and Chan, C. K.: Oligomeric products and formation mechanisms from acid-catalyzed reactions of methyl vinyl ketone on acidic sulfate particles, J. Atmos. Chem., 70, 1-18, doi:10.1007/S10874-013-9248-7, 2013.

Chang, D. and Song, Y.: Estimates of biomass burning emissions in tropical Asia based on satellite-derived data, Atmos. Chem. Phys., 10, 2335-2351, doi:10.5194/acp-10-2335-2010, 2010.

Christian, T. J., Kleiss, B., Yokelson, R. J., Holzinger, R., Crutzen, P. J., Hao, W. M., Saharjo, B. H., and Ward, D. E.: Comprehensive laboratory measurements of biomass-burning emissions: 1 . Emissions from Indonesian, African, and other fuels, J. Geophys. Res.-Atmos., 108, 4719, doi:10.1029/2003jd003704, 2003.

Christian, T. J., Kleiss, B., Yokelson, R. J., Holzinger, R., Crutzen, P. J., Hao, W. M., Shirai, T., and Blake, D. R.: Comprehensive laboratory measurements of biomass-burning emissions: 2. First intercomparison of open-path FTIR, PTR-MS, and GC- MS/FID/ECD, J. Geophys. Res.-Atmos., 109, D02311, doi:10.1029/2003jd003874, 2004.

Ciccioli, P., Brancaleoni, E., Frattoni, M., Cecinato, A., and Pinciarelli, L.: Determination of volatile organic compounds (VOC) emitted from biomass burning of Mediterranean vegetation species by GC-MS, Anal. Lett., 34, 937-955, 2001.

Colmenar, I., Cabañas, B., Martínez, E., Salgado, M. S., and Martín, P.: Atmospheric fate of a series of furanaldehydes by their NO3 reactions, Atmos. Environ., 54, 177-184, doi:10.1016/j.atmosenv.2012.02.087, 2012.

Crutzen, P. J. and Andreae, M. O.: Biomass Burning in the Tropics Impact on Atmospheric Chemistry and Biogeochemical Cycles, Science, 250, 1669-1678, 1990.

Cumming, S. G.: Forest type and wildfire in the alberta boreal mixedwood: What do fires burn?, Ecol. Appl., 11, 97-110, 2001.

Desalmand, F. and Serpolay, R.: Some specific features of the aerosol-particle concentrations during the dry season and during a bushfire event in West-Africa, Atmos. Environ., 19, 15351543, 1985.

Eom, I. Y., Kim, J. Y., Kim, T. S., Lee, S. M., Choi, D., Choi, I. G., and Choi, J. W.: Effect of essential inorganic metals on primary thermal degradation of lignocellulosic biomass, Bioresource Technol., 104, 687-694, doi:10.1016/j.biortech.2011.10.035, 2012.

Eom, I. Y., Kim, J. Y., Lee, S. M., Cho, T. S., Yeo, H., and Choi, J. W.: Comparison of pyrolytic products produced from inorganicrich and demineralized rice straw (Oryza sativa L.) by fluidized bed pyrolyzer for future biorefinery approach, Bioresource Technol., 128, 664-672, doi:10.1016/J.Biortech.2012.09.082, 2013.
Finlayson-Pitts, B. J. and Pitts, J. N.: Chemistry of the Upper and Lower Atmosphere: Theory, Experiments, and Applications, Academic Press, San Diego, p. 208, 2000.

Fitzpatrick, E. M., Jones, J. A., Pourkashanian, M., Ross, A. B., Williams, A., and Bartle, K. D.: Mechanistic aspects of soot formation from the combustion of pine wood, Energy Fuels, 22, 3771-3778, 2008.

Friedli, H. R., Atlas, E., Stroud, V. R., Giovanni, L., Campos, T., and Radke, L. F.: Volatile organic trace gases emitted from North American wildfires, Global Biogeochem. Cy., 15, 435452, 2001.

Gómez Alvarez, E., Borrás, E., Viidanoja, J., and Hjorth, J.: Unsaturated dicarbonyl products from the $\mathrm{OH}$-initiated photo-oxidation of furan, 2-methylfuran and 3-methylfuran, Atmos. Environ., 43, 1603-1612, doi:10.1016/j.atmosenv.2008.12.019, 2009.

Goode, J. G., Yokelson, R. J., Ward, D. E., Susott, R. A., Babbitt, R. E., Davies, M. A., and Hao, W. M.: Measurements of excess $\mathrm{O}_{3}, \mathrm{CO}_{2}, \mathrm{CO}, \mathrm{CH}_{4}, \mathrm{C}_{2} \mathrm{H}_{4}, \mathrm{C}_{2} \mathrm{H}_{2}, \mathrm{HCN}, \mathrm{NO}, \mathrm{NH}_{3}$, $\mathrm{HCOOH}, \mathrm{CH}_{3} \mathrm{COOH}, \mathrm{HCHO}$, and $\mathrm{CH}_{3} \mathrm{OH}$ in 1997 Alaskan biomass burning plumes by airborne fourier transform infrared spectroscopy (AFTIR), J. Geophys. Res.-Atmos., 105, 22147 22166, 2000.

Grieshop, A. P., Logue, J. M., Donahue, N. M., and Robinson, A. L.: Laboratory investigation of photochemical oxidation of organic aerosol from wood fires 1: measurement and simulation of organic aerosol evolution, Atmos. Chem. Phys., 9, 1263-1277, doi:10.5194/acp-9-1263-2009, 2009.

Griffin, R. J., Cocker, D. R., Flagan, R. C., and Seinfeld, J. H.: Organic aerosol formation from the oxidation of biogenic hydrocarbons, J. Geophys. Res., 104, 3555-3567, 1999.

Haines, T. K. and Busby, R. L.: Prescribed burning in the South: Trends, purpose, and barriers, Journal of Applied Forestry, 25, 149-153, 2001.

Hallquist, M., Wenger, J. C., Baltensperger, U., Rudich, Y., Simpson, D., Claeys, M., Dommen, J., Donahue, N. M., George, C., Goldstein, A. H., Hamilton, J. F., Herrmann, H., Hoffmann, T., Iinuma, Y., Jang, M., Jenkin, M. E., Jimenez, J. L., Kiendler-Scharr, A., Maenhaut, W., McFiggans, G., Mentel, Th. F., Monod, A., Prévôt, A. S. H., Seinfeld, J. H., Surratt, J. D., Szmigielski, R., and Wildt, J.: The formation, properties and impact of secondary organic aerosol: current and emerging issues, Atmos. Chem. Phys., 9, 5155-5236, doi:10.5194/acp-9-51552009, 2009.

Hatfield, M. L. and Hartz, K. E. H.: Secondary organic aerosol from biogenic volatile organic compound mixtures, Atmos. Environ., 45, 2211-2219, 2011.

Heald, C. L., Coe, H., Jimenez, J. L., Weber, R. J., Bahreini, R., Middlebrook, A. M., Russell, L. M., Jolleys, M., Fu, T.-M., Allan, J. D., Bower, K. N., Capes, G., Crosier, J., Morgan, W. T., Robinson, N. H., Williams, P. I., Cubison, M. J., DeCarlo, P. F., and Dunlea, E. J.: Exploring the vertical profile of atmospheric organic aerosol: comparing 17 aircraft field campaigns with a global model, Atmos. Chem. Phys., 11, 12673-12696, doi:10.5194/acp-11-12673-2011, 2011.

Heil, A.: Indonesian forest and peat fires: Emissions, air quality, and human health, PhD, Max Planck Institute for Meteorology, Hamburg, 142 pp., 2007. 
Helmig, D.: Ozone removal techniques in the sampling of atmospheric volatile organic trace gases, Atmos. Environ., 31, 36353651, 1997.

Helmig, D., Revermann, T., Pollmann, J., Kaltschmidt, O., Hernandez, A. J., Bocquet, F., and David, D.: Calibration system and analytical considerations for quantitative sesquiterpene measurements in air, J. Chromatogr. A, 1002, 193-211, doi:10.1016/s0021-9673(03)00619-8, 2003.

Helmig, D., Bocquet, F., Pollmann, J., and Revermann, T.: Analytical techniques for sesquiterpene emission rate studies in vegetation enclosure experiments, Atmos. Environ., 38, 557-572, doi:10.1016/j.atmosenv.2003.10.012, 2004.

Hennigan, C. J., Miracolo, M. A., Engelhart, G. J., May, A. A., Presto, A. A., Lee, T., Sullivan, A. P., McMeeking, G. R., Coe, H., Wold, C. E., Hao, W.-M., Gilman, J. B., Kuster, W. C., de Gouw, J., Schichtel, B. A., Collett Jr., J. L., Kreidenweis, S. M., and Robinson, A. L.: Chemical and physical transformations of organic aerosol from the photo-oxidation of open biomass burning emissions in an environmental chamber, Atmos. Chem. Phys., 11, 7669-7686, doi:10.5194/acp-11-7669-2011, 2011.

Hobbs, P. V., Reid, J. S., Kotchenruther, R. A., Ferek, R. J., and Weiss, R.: Direct radiative forcing by smoke from biomass burning, Science, 275, 1776-1778, 1997.

Hobbs, P. V., Sinha, P., Yokelson, R. J., Christian, T. J., Blake, D. R., Gao, S., Kirchstetter, T. W., Novakov, T., and Pilewskie, P.: Evolution of gases and particles from a savanna fire in South Africa, J. Geophys. Res.-Atmos., 108, 8485, doi:10.1029/2002jd002352, 2003.

Jaffe, D., Bertschi, I., Jaegle, L., Novelli, P., Reid, J. S., Tanimoto, H., Vingarzan, R., and Westphal, D. L.: Long-range transport of Siberian biomass burning emissions and impact on surface ozone in western North America, Geophys. Res. Lett., 31, L16106, doi:10.1029/2004g1020093, 2004.

Jiang, G. Z., Nowakowski, D. J., and Bridgwater, A. V.: Effect of the Temperature on the Composition of Lignin Pyrolysis Products, Energy Fuels, 24, 4470-4475, 2010.

Jolleys, M. D., Coe, H., McFiggans, G., Capes, G., Allan, J. D., Crosier, J., Williams, P. I., Allen, G., Bower, K. N., Jimenez, J. L., Russell, L. M., Grutter, M., and Baumgardner, D.: Characterizing the aging of biomass burning organic aerosol by use of mixing ratios: A meta-analysis of four regions, Environ. Sci. Technol., 46, 13093-13102, 2012.

Kanakidou, M., Seinfeld, J. H., Pandis, S. N., Barnes, I., Dentener, F. J., Facchini, M. C., Van Dingenen, R., Ervens, B., Nenes, A., Nielsen, C. J., Swietlicki, E., Putaud, J. P., Balkanski, Y., Fuzzi, S., Horth, J., Moortgat, G. K., Winterhalter, R., Myhre, C. E. L., Tsigaridis, K., Vignati, E., Stephanou, E. G., and Wilson, J.: Organic aerosol and global climate modelling: a review, Atmos. Chem. Phys., 5, 1053-1123, doi:10.5194/acp-5-1053-2005, 2005.

Kesselmeier, J. and Staudt, M.: Biogenic volatile organic compounds (VOC): An overview on emission, physiology and ecology, J. Atmos. Chem., 33, 23-88, 1999.

Krauze-Baranowska, M., Mardarowicz, M., Wiwart, M., Poblocka, L., and Dynowska, M.: Antifungal activity of the essential oils from some species of the genus Pinus, Z. Naturforsch. C., 57, 478-482, 2002.

Kroll, J. H. and Seinfeld, J. H.: Chemistry of secondary organic aerosol: Formation and evolution of low-volatility or- ganics in the atmosphere, Atmos. Environ., 42, 3593-3624, doi:10.1016/j.atmosenv.2008.01.003, 2008.

Laskin, A., Smith, J. S., and Laskin, J.: Molecular characterization of nitrogen-containing organic compounds in biomass burning aerosols using high-resolution mass spectrometry, Environ. Sci. Technol., 43, 3764-3771, 2009.

Lee, A., Goldstein, A. H., Kroll, J. H., Ng, N. L., Varutbangkul, V., Flagan, R. C., and Seinfeld, J. H.: Gas-phase products and secondary aerosol yields from the photooxidation of 16 different terpenes, J. Geophys. Res., 111, D17305, doi:10.1029/2006jd007050, 2006.

Lim, Y. B. and Ziemann, P. J.: Effects of molecular structure on aerosol yields from $\mathrm{OH}$ radical-initiated reactions of linear, branched, and cyclic alkanes in the presence of $\mathrm{NO}_{\mathrm{x}}$, Environ. Sci. Technol., 43, 2328-2334, doi:10.1021/Es803389s, 2009.

Linstrom, P. J. and Mallard, W. G. (Eds.): National Institute of Standards and Technology, Gaithersburg MD, 20899, http://webbook. nist.gov, 2014

Liu, Y., Siekmann, F., Renard, P., El Zein, A., Salque, G., El Haddad, I., Temime-Roussel, B., Voisin, D., Thissen, R., and Monod, A.: Oligomer and SOA formation through aqueous phase photooxidation of methacrolein and methyl vinyl ketone, Atmos. Environ., 49, 123-129, doi:10.1016/J.Atmosenv.2011.12.012, 2012.

Lobert, J. M. and Warnatz, J.: Emissions from the Combustion Process in Vegetation, in: Fire in the Environment: The Ecological, Atmospheric, and Climatic Importance of Vegetation Fires, edited by: Crutzen, P. J. and Goldammer, J. G., John Wiley \& Sons Ltd., New York, 15-37, 1993.

Lohmann, U. and Feichter, J.: Global indirect aerosol effects: a review, Atmos. Chem. Phys., 5, 715-737, doi:10.5194/acp-5-7152005, 2005.

Ma, Y. L. and Hays, M. D.: Thermal extraction-two-dimensional gas chromatography-mass spectrometry with heart-cutting for nitrogen heterocyclics in biomass burning aerosols, J. Chromatogr. A, 1200, 228-234, doi:10.1016/j.chroma.2008.05.078, 2008.

Ma, Y., Hays, M. D., Geron, C. D., Walker, J. T., and Gatari Gichuru, M. J.: Technical Note: Fast two-dimensional GC-MS with thermal extraction for anhydro-sugars in fine aerosols, Atmos. Chem. Phys., 10, 4331-4341, doi:10.5194/acp-10-43312010, 2010.

Matsunaga, A., Docherty, K. S., Lim, Y. B., and Ziemann, P. J.: Composition and yields of secondary organic aerosol formed from $\mathrm{OH}$ radical-initiated reactions of linear alkenes in the presence of $\mathrm{NO}_{\mathrm{x}}$ : Modeling and measurements, Atmos. Environ., 43, 1349-1357, 2009.

McMeeking, G. R., Kreidenweis, S. M., Baker, S., Carrico, C. M., Chow, J. C., Collett, J. L., Hao, W. M., Holden, A. S., Kirchstetter, T. W., Malm, W. C., Moosmuller, H., Sullivan, A. P., and Wold, C. E.: Emissions of trace gases and aerosols during the open combustion of biomass in the laboratory, J. Geophys. Res.Atmos., 114, D19210, doi:10.1029/2009jd011836, 2009.

Meinardi, S., Simpson, I. J., Blake, N. J., Blake, D. R., and Rowland, F. S.: Dimethyl disulfide (DMDS) and dimethyl sulfide (DMS) emissions from biomass burning in Australia, Geophys. Res. Lett., 30, 1454, doi:10.1029/2003GL016967, 2003.

Mondello, L., Tranchida, P. Q., Dugo, P., and Dugo, G.: Comprehensive two-dimensional gas chromatography-mass spec- 
trometry: A review, Mass. Spectrom. Rev., 27, 101-124, doi:10.1002/Mas.20158, 2008.

Mulholland, J. A., Lu, M., and Kim, D. H.: Pyrolytic growth of polycyclic aromatic hydrocarbons by cyclopentadienyl moieties, P. Combust. Inst., 28, 2593-2599, 2000.

Nakao, S., Clark, C., Tang, P., Sato, K., and Cocker III, D.: Secondary organic aerosol formation from phenolic compounds in the absence of $\mathrm{NO}_{\mathrm{x}}$, Atmos. Chem. Phys., 11, 10649-10660, doi:10.5194/acp-11-10649-2011, 2011.

Nara, H., Nakagawa, F., and Yoshida, N.: Development of twodimensional gas chromatography/isotope ratio mass spectrometry for the stable carbon isotopic analysis of $\mathrm{C}(2)-\mathrm{C}(5)$ nonmethane hydrocarbons emitted from biomass burning, Rapid Commun. Mass. Sp., 20, 241-247, doi:10.1002/Rcm.2302, 2006.

Nasri, N., Tlili, N., Triki, S., Elfalleh, W., Cheraif, I., and Khaldi, A.: Volatile Constituents of Pinus pinea L. Needles, J. Essent. Oil Res., 23, 15-19, 2011.

Ng, N. L., Kroll, J. H., Chan, A. W. H., Chhabra, P. S., Flagan, R. C., and Seinfeld, J. H.: Secondary organic aerosol formation from $m$-xylene, toluene, and benzene, Atmos. Chem. Phys., 7, 3909-3922, doi:10.5194/acp-7-3909-2007, 2007.

Oanh, N. T. K., Ly, B. T., Tipayarom, D., Manandhar, B. R., Prapat, P., Simpson, C. D., and Liu, L. J. S.: Characterization of particulate matter emission from open burning of rice straw, Atmos. Environ., 45, 493-502, doi:10.1016/J.Atmosenv.2010.09.023, 2011.

Odum, J. R., Hoffmann, T., Bowman, F., Collins, D., Flagan, R. C., and Seinfeld, J. H.: Gas/particle partitioning and secondary organic aerosol yields, Environ. Sci. Technol., 30, 2580-2585, doi:10.1021/Es950943+, 1996.

Ortega, A. M., Day, D. A., Cubison, M. J., Brune, W. H., Bon, D., de Gouw, J. A., and Jimenez, J. L.: Secondary organic aerosol formation and primary organic aerosol oxidation from biomass-burning smoke in a flow reactor during FLAME-3, Atmos. Chem. Phys., 13, 11551-11571, doi:10.5194/acp-1311551-2013, 2013.

Page, S. E., Siegert, F., Rieley, J. O., Boehm, H. D. V., Jaya, A., and Limin, S.: The amount of carbon released from peat and forest fires in Indonesia during 1997, Nature, 420, 61-65, 2002.

Paine, J. B., Pithawalla, Y. B., and Naworal, J. D.: Carbohydrate pyrolysis mechanisms from isotopic labeling Part 4. The pyrolysis Of D-glucose: The formation of furans, J. Anal. Appl. Pyrol., 83, 37-63, 2008a.

Paine, J. B., Pithawalla, Y. B., and Naworal, J. D.: Carbohydrate pyrolysis mechanisms from isotopic labeling. Part 3. The Pyrolysis of D-glucose: Formation of C-3 and C-4 carbonyl compounds and a cyclopentenedione isomer by electrocyclic fragmentation mechanisms, J. Anal. Appl. Pyrol., 82, 42-69, 2008 b.

Pandey, M. P. and Kim, C. S.: Lignin Depolymerization and Conversion: A Review of Thermochemical Methods, Chem. Eng. Technol., 34, 29-41, doi:10.1002/ceat.201000270, 2011.

Pankow, J. F., Luo, W. T., Isabelle, L. M., Bender, D. A., and Baker, R. J.: Determination of a wide range of volatile organic compounds in ambient air using multisorbent adsorption/thermal desorption and gas chromatography mass spectrometry, Anal. Chem., 70, 5213-5221, doi:10.1021/Ac980481t, 1998.

Pankow, J. F., Luo, W., Melnychenko, A. N., Barsanti, K. C., Isabelle, L. M., Chen, C., Guenther, A. B., and Rosenstiel, T. N.: Volatilizable Biogenic Organic Compounds (VBOCs) with two dimensional Gas Chromatography-Time of Flight Mass Spectrometry $(\mathrm{GC} \times \mathrm{GC}-\mathrm{TOFMS})$ : sampling methods, VBOC complexity, and chromatographic retention data, Atmos. Meas. Tech., 5, 345-361, doi:10.5194/amt-5-345-2012, 2012.

Patwardhan, P. R., Satrio, J. A., Brown, R. C., and Shanks, B. H.: Influence of inorganic salts on the primary pyrolysis products of cellulose, Bioresource Technol., 101, 4646-4655, doi:10.1016/J.Biortech.2010.01.112, 2010.

Petters, M. D., Parsons, M. T., Prenni, A. J., DeMott, P. J., Kreidenweis, S. M., Carrico, C. M., Sullivan, A. P., McMeeking, G. R., Levin, E., Wold, C. E., Collett, J. L., and Moosmuller, H.: Ice nuclei emissions from biomass burning, J. Geophys. Res.-Atmos. 114, D07209, doi:10.1029/2008jd011532, 2009.

Pollmann, J., Ortega, J., and Helmig, D.: Analysis of atmospheric sesquiterpenes: Sampling losses and mitigation of ozone interferences, Environ. Sci. Technol., 39, 9620-9629, 2005.

Pope, C. A. and Dockery, D. W.: Health effects of fine particulate air pollution: Lines that connect, J. Air Waste Manage., 56, 709742, 2006

Presto, A. A., Miracolo, M. A., Donahue, N. M., and Robinson, A. L.: Secondary organic aerosol formation from high-NOx photooxidation of low volatility precursors: n-Alkanes, Environ. Sci. Technol., 44, 2029-2034, 2010.

Reid, J. S., Koppmann, R., Eck, T. F., and Eleuterio, D. P.: A review of biomass burning emissions part II: intensive physical properties of biomass burning particles, Atmos. Chem. Phys., 5, 799825, doi:10.5194/acp-5-799-2005, 2005.

Saiz-Jimenez, C. and De Leeuw, J. W.: Lignin pyrolysis products: Their structures and their significance as biomarkers, Organic Geochemistry, 10, 869-876, 1986.

Saxena, P., Hildemann, L. M., Mcmurry, P. H., and Seinfeld, J. H.: Organics alter hygroscopic behavior of atmospheric particles, J. Geophys. Res.-Atmos., 100, 18755-18770, 1995.

Schauer, J. J., Kleeman, M. J., Cass, G. R., and Simoneit, B. R. T.: Measurement of emissions from air pollution sources. 3. C1-C-29 organic compounds from fireplace combustion of wood, Environ. Sci. Technol., 35, 1716-1728, 2001.

Seinfeld, J. H. and Pankow, J. F.: Organic atmospheric particulate material, Annu. Rev. Phys. Chem., 54, 121-140, doi:10.1146/annurev.physchem.54.011002.103756, 2003.

Shafizadeh, F.: Introduction to Pyrolysis of Biomass, J. Anal. Appl. Pyrol., 3, 283-305, 1982.

Simpson, I. J., Akagi, S. K., Barletta, B., Blake, N. J., Choi, Y., Diskin, G. S., Fried, A., Fuelberg, H. E., Meinardi, S., Rowland, F. S., Vay, S. A., Weinheimer, A. J., Wennberg, P. O., Wiebring, P., Wisthaler, A., Yang, M., Yokelson, R. J., and Blake, D. R.: Boreal forest fire emissions in fresh Canadian smoke plumes: $\mathrm{C}_{1}-\mathrm{C}_{10}$ volatile organic compounds (VOCs), $\mathrm{CO} 2, \mathrm{CO}, \mathrm{NO}_{2}$, NO, $\mathrm{HCN}$ and $\mathrm{CH}_{3} \mathrm{CN}$, Atmos. Chem. Phys., 11, 6445-6463, doi:10.5194/acp-11-6445-2011, 2011.

Smith, J. D., Sio, V., Yu, L., Zhang, Q., and Anastasio, C.: Secondary organic aerosol production from aqueous reactions of atmospheric phenols with an organic triplet excited state, Environ Sci. Technol., 48, 1049-1057, doi:10.1021/Es4045715, 2014.

Sojak, L., Hrivnak, J., Majer, P., and Janak, J.: Capillary gaschromatography of linear alkenes on squalane, Anal. Chem., 45, 293-302, 1973. 
Sojak, L., Kralovicova, E., Ostrovsky, I., and Leclercq, P. A.: Retention behavior of conjugated and isolated normal-alkadienes - identification of normal-nonadiene and normal-decadiene by capillary gas-chromatography using structure retention correlations and mass-spectrometry, J. Chromatogr., 292, 241-261, 1984.

Stein, S. E.: Retention Indices, in: NIST Chemistry WebBook, NIST Standard Reference Database Number 69, edited by: Linstrom, P. J. and Mallard, W. G., National Institute of Standards and Technology, Gaithersburg, MD, available at: http://webbook. nist.gov, last access: October 2013.

Stockwell, C. E., Yokelson, R. J., Kreidenweis, S. M., Robinson, A. L., DeMott, P. J., Sullivan, R. C., Reardon, J., Ryan, K. C., Griffith, D. W. T., and Stevens, L.: Trace gas emissions from combustion of peat, crop residue, domestic biofuels, grasses, and other fuels: configuration and Fourier transform infrared (FTIR) component of the fourth Fire Lab at Missoula Experiment (FLAME4), Atmos. Chem. Phys., 14, 9727-9754, doi:10.5194/acp-149727-2014, 2014.

Stolle, A., Ondruschka, B., and Hopf, H.: Thermal Rearrangements of Monoterpenes and Monoterpenoids, Helv. Chim. Acta, 92, 1673-1719, 2009.

Streets, D. G., Yarber, K. F., Woo, J. H., and Carmichael, G. R.: Biomass burning in Asia: Annual and seasonal estimates and atmospheric emissions, Global Biogeochem. Cy., 17, 1099, doi:10.1029/2003GB002040, 2003.

Strollo, C. M. and Ziemann, P. J.: Products and mechanism of secondary organic aerosol formation from the reaction of 3methylfuran with $\mathrm{OH}$ radicals in the presence of $\mathrm{NO}_{\mathrm{x}}$, Atmos. Environ., 77, 534-543, 2013.

Sun, Y. L., Zhang, Q., Anastasio, C., and Sun, J.: Insights into secondary organic aerosol formed via aqueous-phase reactions of phenolic compounds based on high resolution mass spectrometry, Atmos. Chem. Phys., 10, 4809-4822, doi:10.5194/acp-104809-2010, 2010.

Surratt, J. D., Murphy, S. M., Kroll, J. H., Ng, N. L., Hildebrandt, L., Sorooshian, A., Szmigielski, R., Vermeylen, R., Maenhaut, W., Claeys, M., Flagan, R. C., and Seinfeld, J. H.: Chemical composition of secondary organic aerosol formed from the photooxidation of isoprene, J. Phys. Chem. A, 110, 9665-9690, 2006.

Tong, H. Y. and Karasek, F. W.: Flame ionization detector response factors for compound classes in quantitative-analysis of complex organic mixtures, Anal. Chem., 56, 2124-2128, 1984.

USDA, NRCS, The PLANTS Database (http://plants.usda.gov), National Plant Data Team, Greensboro, NC 27401-4901 USA, 2014.

Vakkari, V., Kerminen, V. M., Beukes, J. P., Tiitta, P., van Zyl, P. G., Josipovic, M., Venter, A. D., Jaars, K., Worsnop, D. R., Kulmala, M., and Laakso, L.: Rapid changes in biomass burning aerosols by atmospheric oxidation, Geophys. Res. Lett., 41, 2644-2651, 10.1002/2014g1059396, 2014.

van der Werf, G. R., Randerson, J. T., Giglio, L., Collatz, G. J., Mu, M., Kasibhatla, P. S., Morton, D. C., DeFries, R. S., Jin, Y., and van Leeuwen, T. T.: Global fire emissions and the contribution of deforestation, savanna, forest, agricultural, and peat fires (19972009), Atmos. Chem. Phys., 10, 11707-11735, doi:10.5194/acp10-11707-2010, 2010.
Veblen, T. T., Kitzberger, T., and Donnegan, J.: Climatic and human influences on fire regimes in ponderosa pine forests in the Colorado Front Range, Ecol. Appl., 10, 1178-1195, 2000.

von Rudloff, E.: Seasonal Variation in the Terpenes of the Foliage of Black Spruce, Phytochemistry, 14, 1695-1699, 1975.

Wade, D. D., Brock, B. L., Brose, P. H., Grace, J. B., Hoch, G. A., and Patterson, W. A.: Fire in Eastern Ecosystems, in: Wildland Fire in Ecosystems: Effects of Fire on Flora. Gen. Tech. Rep. RMRS-GTR-42-vol. 2, edited by: Brown, J. K. and Smith, J. K., US Department of Agriculture, Forest Service, Rocky Mountain Research Station, Ogden, UT, 53-96, 2000.

Ward, D. E.: Factors Influencing the Emissions of Gases and Particulate Matter from Biomass Burning, in: Fire in the Tropical Biota: Ecosystem Processes and Global Challenges, edited by: Goldammer, J. G., Springer-Verlag, Berlin, Germany, 418-436, 1990.

Warneke, C., Roberts, J. M., Veres, P., Gilman, J., Kuster, W. C., Burling, I., Yokelson, R., and de Gouw, J. A.: VOC identification and inter-comparison from laboratory biomass burning using PTR-MS and PIT-MS, Int. J. Mass. Spectrom., 303, 6-14, doi:10.1016/j.ijms.2010.12.002, 2011.

Wiedinmyer, C., Akagi, S. K., Yokelson, R. J., Emmons, L. K., AlSaadi, J. A., Orlando, J. J., and Soja, A. J.: The Fire INventory from NCAR (FINN): a high resolution global model to estimate the emissions from open burning, Geosci. Model Dev., 4, 625641, doi:10.5194/gmd-4-625-2011, 2011.

Wigder, N. L., Jaffe, D. A., and Saketa, F. A.: Ozone and particulate matter enhancements from regional wildfires observed at Mount Bachelor during 2004-2011, Atmos. Environ., 75, 24-31, 2013.

Yee, L. D., Kautzman, K. E., Loza, C. L., Schilling, K. A., Coggon, M. M., Chhabra, P. S., Chan, M. N., Chan, A. W. H., Hersey, S. P., Crounse, J. D., Wennberg, P. O., Flagan, R. C., and Seinfeld, J. H.: Secondary organic aerosol formation from biomass burning intermediates: phenol and methoxyphenols, Atmos. Chem. Phys., 13, 8019-8043, doi:10.5194/acp-13-8019-2013, 2013.

Yokelson, R. J., Griffith, D. W. T., and Ward, D. E.: Openpath Fourier transform infrared studies of large-scale laboratory biomass fires, J. Geophys. Res.-Atmos., 101, 21067-21080, 1996.

Yokelson, R. J., Goode, J. G., Ward, D. E., Susott, R. A., Babbitt, R. E., Wade, D. D., Bertschi, I., Griffith, D. W. T., and Hao, W. M.: Emissions of formaldehyde, acetic acid, methanol, and other trace gases from biomass fires in North Carolina measured by airborne Fourier transform infrared spectroscopy, J. Geophys. Res., 104, 30109-30125, 1999.

Yokelson, R. J., Bertschi, I. T., Christian, T. J., Hobbs, P. V., Ward, D. E., and Hao, W. M.: Trace gas measurements in nascent, aged, and cloud-processed smoke from African savanna fires by airborne Fourier transform infrared spectroscopy (AFTIR), J. Geophys. Res.-Atmos., 108, 4649, doi:10.1029/2002jd002322, 2003.

Yokelson, R. J., Crounse, J. D., DeCarlo, P. F., Karl, T., Urbanski, S., Atlas, E., Campos, T., Shinozuka, Y., Kapustin, V., Clarke, A. D., Weinheimer, A., Knapp, D. J., Montzka, D. D., Holloway, J., Weibring, P., Flocke, F., Zheng, W., Toohey, D., Wennberg, P. O., Wiedinmyer, C., Mauldin, L., Fried, A., Richter, D., Walega, J., Jimenez, J. L., Adachi, K., Buseck, P. R., Hall, S. R., and Shetter, R.: Emissions from biomass burning in the Yucatan, Atmos. Chem. Phys., 9, 5785-5812, doi:10.5194/acp-9-5785-2009, 2009. 
Yokelson, R. J., Burling, I. R., Gilman, J. B., Warneke, C., Stockwell, C. E., de Gouw, J., Akagi, S. K., Urbanski, S. P., Veres, P., Roberts, J. M., Kuster, W. C., Reardon, J., Griffith, D. W. T., Johnson, T. J., Hosseini, S., Miller, J. W., Cocker III, D. R., Jung, H., and Weise, D. R.: Coupling field and laboratory measurements to estimate the emission factors of identified and unidentified trace gases for prescribed fires, Atmos. Chem. Phys., 13, 89-116, doi:10.5194/acp-13-89-2013, 2013.
Ziemann, P. J.: Effects of molecular structure on the chemistry of aerosol formation from the $\mathrm{OH}$-radical-initiated oxidation of alkanes and alkenes, Int. Rev. Phys. Chem., 30, 161-195, 2011.

Ziemann, P. J. and Atkinson, R.: Kinetics, products, and mechanisms of secondary organic aerosol formation, Chem. Soc. Rev., 41, 6582-6605, 2012. 